S B

355

G82

\title{
UC-NRLF
}

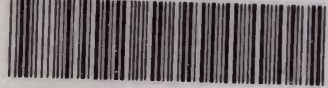

\$B 307 669

\section{Amateur • Fruit • Growing.}




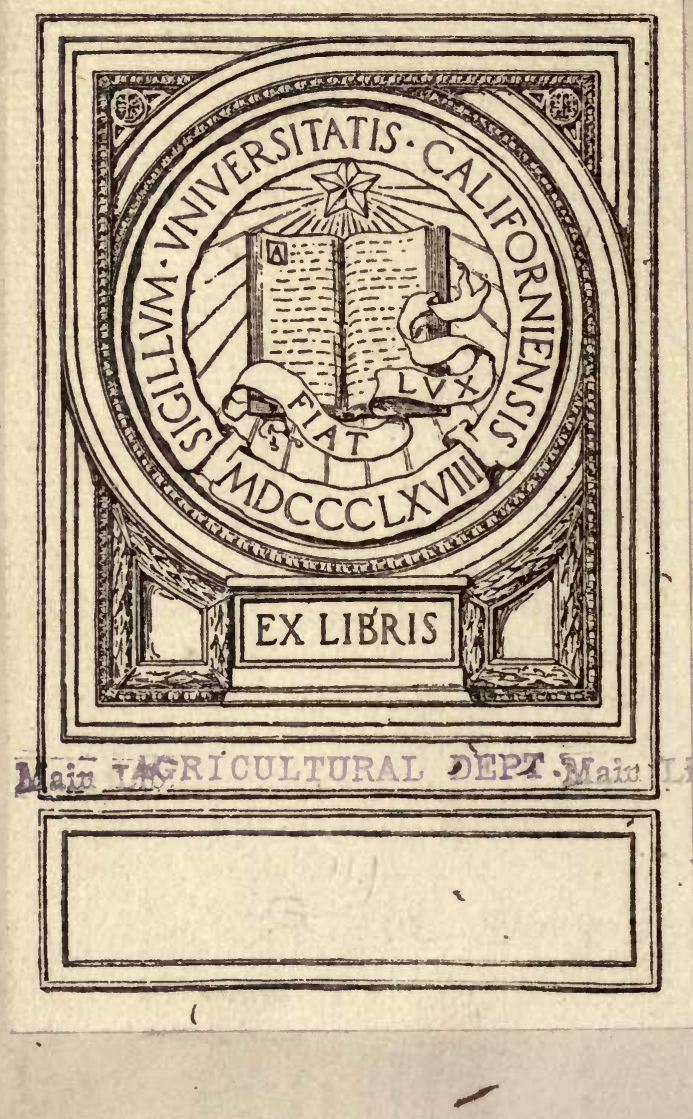


From the collection of the

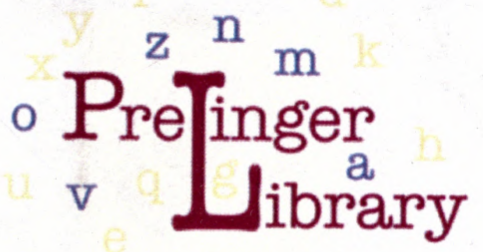

t

$\mathrm{p}$

San Francisco, California

2006 





\section{AMATEUR FRUIT GROWING.}

A Practical Guide to the Growing of Fruit for Home Use and the Market.

Written with Special Reference to Colder Climates.

BY

SAMUEL B. GREEN,

Professor of Horticulture in the University of Minnesota.

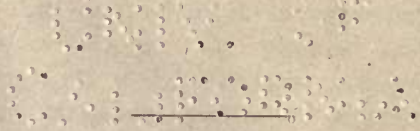

MINNEAPOLIS :

Farm, Stock and Home Publishing Co., 1894. 


$$
53355
$$

482

COPYright, 1893.
BY SAMLEL B, GREEN

Main tibietur Segat 


\section{INTRODUCTION.}

IN my experience as teacher of Horticulture in the School of 1 Agriculture of the University of Minnesota I have not been able to find a book on fruit growing at all adapted to the wants of the students coming under my instruction. In fact, I soon found that the material along this line consisted principally of papers scattered through reports of the various horticultural societies and in the agricultural press, and that these were not generally available, nor, indeed, sufficiently condensed for my purpose. The peculiar conditions that obtain in this section of the country, and which render the works of Eastern authorities of little practical value here, made it desirable for me to have some practical book on fruit growing that the students could study and refer to at their convenience.

Another reason for presenting this book is that by so doing I might answer the many questions relating to the subject treated, which have been often referred to me, and which have required much time and attention in correspondence.

The book is written for the beginner and is not offered as a complete manual of Horticulture, although it is believed to cover all the important points in practical fruit growing. But few varieties are recommended, and only the kinds tiad have been tried for some considerable period and can be obtained from the general nurserymen. Untried and little known kinds have been purposely avoided, however well they may have appeared. It is my earnest wish that new varieties be let alone by the amateur in horticulture, and that, instead of beginning with novelties in fruits, as is too often the case, he will postpone their trial until he has first tried those kinds that are known to be desirable. 
Varieties of many fruits, especially of small fruits, seldom last in full vigor for more than a score of years, and often after a much less time they are superceded by new and better kinds. There are many novelties in frults introduced each year, but in my experience not one new variety in ten that is offered for sale is worthy of trial. It is my intention to issue a supplementary fruit list as often as may seem desirable, and lists of fruits recommended in this work may be supplemented by reference to the fruit lists of the different horticultural societies.

The Appendix at the end of the volume by Professor J. L. Budd, of the Iowa Agricultural College, adds much to the value of the list of fruits, and is here included for the benefit of planters living in the latitude of Northern Iowa and Illinois and Southern Minnesota, and to him my thanks are due for this assistance.

\section{SAMUEL B, GREFN.}

St. Anthony Park, December 15, 1593. 


\section{CHAPTER}

\section{STRAWBERRIES.}

I

HE strawberry is the most important of the small fruits. It is found growing from the far north to the hot south, and across the Continent. There is not a state in this country but has its wild strawberries. There are large sections of Minnesota where the strawberry produces as heavily as it does anywhere when given good cultivation, and there is not a county in the state where it cannot be made to yield abundantly. It is easily grown, stands transportation moderately well, and is almost universally admired.

Species.-There are three species of the strawberry commonly met with in cultivation:-

(1) Fragaria Virginiana, which forms entirely or enters largely into the parentage of the varieties that have become widely known and esteemed on account of their hardiness and reliability.

(2) Fragaria grandiflora, the South American strawberry, is grown much more extensively in eastern Europe than in this country. This variety readily hybridizes with the $F$. Virgiviana, but in a pure state is not sufficiently hardy to withstand successfully our hot summers and cold winters. It has very handsome, large fruit, but it has not the sprightly quality of our native berry.

(3) Fragaria vesca, called the Alpine or wood strawberry, is a natire of Europe and of the northern parts of this country and Canada. From this have come the ever-bearing varieties whose praises are so often talked of. It will not hybridize with either of the two kinds previously mentioned. This species is not sufficiently productive to warrant its being largely cultivated. The everbearing or perpetual varieties are not desirable. They produce a few berries all through the season, but do not produce enough at any one time to make their cultivation an object of importance. Practically, then, this species is of little account.

Propagation.-The strawberry is increased by seed, runners and plant divisions. The plants do not "come true" from seed, but seedlings vary very much in their value for cultivation. Probably 
not one plant in five thousand seedlings that may be raised will be as good as any of the best half dozen varieties now in cultivation, but there will be a good many plants out of such a number that will be fairly productive of good fruit. It is this variability that gives us an opportunity of improving on the kinds now grown. To raise strawberries from seed the ripened berries should be crushed in a small amount of dry sand or loam as soon as they are "dead ripe." The seed and sand should then be sown at once in a somewhat shaded bed of rich soil. It will come up in a few weeks if well cared for. The plants should be transplanted four inches apart in another bed as soon as large enough to handle. By winter, if carefully attended to, they will be of good size and may be moved to the fruiting bed in the spring, where they will fruit the follow. ing year, that is in twa years from tne time the seed was sown. It is a very simple process and may be carried on by any careful person. The raising of seedlings is not often profitable, but is a very fascinating line of experimental work on account of the possibility that one may develop a variety of more than ordinary value.

For practical purposes strawberries are increased only by runners, which most desirable kinds produce in great abundance when growing in rich soil. These runners are attached to the old plant only part of one season, the connection dying the first winter if not before. It is common to separate the runners into old plants and young plants. By old plants is meant the plants that have once borne fruit. They can be distinguished by their black roots, and should never be used except in emergency as they often fail to grow. Plants should never be taken from beds that have fruited. The young runners are what should be set out. They have never fruited, have white roots, and were formed the season just preceding the spring they are set. Strawberries should never be grown from divisions, unless it is necessary to save the stock of a valuable kind.

Location and Soil.-The crop is generally most satisfactory when grown on a northern slope, as it is then not exposed to the drying southerly winds, which in exposed locations occasionally so dry out the land that the crop is seriously lessened; also as the plants start latest on north slopes the blossoms are not liable to be injured by the late spring frosts which sometimes cause serious injury to plants that start early. Some growers, however, are very successful in growing them on southerly slopes or on level land. In a general way any land or location that is good enough for a crop of corn will do admirably for-strawberries, but strawberries should never be planted on sod-land on account of the liability of its being infested with cut-worms, or with the white grub, which feeds on the roots of the plants.

Manure and Preparation of the Land.-The strawberry is a gross feeder and needs plenty of plant food in the soil. The best fertilizer is barn-yard manure that is partially rotted, but it should not be plowed in very deep. It is generally best to plor the 


land deep in autumn, apply the manure in winter or in spring, and then plow the manure under very shallow as soon as may be thereafter. The land should then be thoroughly dragged and smoothed, when it is ready for the plants. When so prepared the land has a loose surface bed in which to place the plants, while underneath it the soil is so firm as to retain the moisture and yet it is open enough so that the young roots can push into it.

Time of Planting. - Practically there is only one time to plant, and that is in the spring. It is occasionally recommended to plant in August. It may be all right to do so in case there is no strawberry bed in the home garden, and there is considerable moisture in the ground so the plants will live without too much care, but in ordinary seasons here the results from setting the plants at this time are very uncertain and do not warrant the planting of them on a large scale. If it is decided to set a bed for the nome garden in August, the plants may be well-rooted layers from some bed near by, or if obtained from a distance they should have been potted and be well rotted in the pots. The potted plants cost more but are much surer to grow than layers. The growers of strawberries for profit in this state always plant in the spring. The earlier the plants can be set the longer the season for them to grow, and the cool, moist weather of early spring seems to favor the formation of roots, but they may be set as late as the first of June with fair prospect of success. However, if the land is very dry at planting time it is best not to plant until after a rain, even if waiting for it may delay the planting considerably. In this climate it is poor practice to set out strawberry plants for profit in dry soil and $t$ ry to keep them growing by watering, as so much water and attention is required that the operation will be found a losing one.

If plants are received when the land is very dry it is the custom of the best growers to open the bundles, shake out the plants, and dip the roots into a clay-loam mud and "heel them in" close together, putting a little soil between the plants. When thus treated they may be easily watered, and will commence to grow and be ready to set out in the field or garden as soon as a favorable time offers. If the space where the plants are heeled in is surrounded by a board fence, or other windbreak, a few feet high, it will aid much in preventing the drying action of the wind.

Plants that have been some time in transit are very apt to look white and weak when received, and are almost sure to die if at once set in the full sunshine. They should be heeled in and partially shaded until they assume their normal color.

Methods of Planting. - There are many methods of planting but I will mention only two ways, and they may be modified as the good judgment of the planter may suggest.

Hill System.-This is especially adapted to the home garden. By it the fruit is grown of a larger size than in the matted rows, but not so much is produced. It consists in setting the plants at about one foot distance in rows two-and-a-half or three feet apart, 
and keeping all the runners cut off. Managed on this plan the plants become very large, have many crowns, look neat and pretty, and produce a good amount of extra large fruit. The objection to it is that it takes three or four times as many plants to set out the land as are needed where the matted-row system is followed, and the crop is not so large. For these reasons this system is not followed by commercial growers.

MATTED-Row Srstem.-All large growers pursue very nearly the following plan: After the land is prepared in the spring it is marked out with a corn-marker, four feet one way and two feet the other, and the plants are set at the intersections. The horse cultirator is run both ways until the plants commence to make runners rapidly (about the middle of July), when it is run only in the fourfoot intervals. The runners are then pusked together forming a bed or matted row, which by autumn will be eighteen inches wide. The ground between the rows should be worked as often as once in ten days throughout the growing season up to the first of September, after which cultivation should cease for the year. Keep the soil loose and be sure the bed is free from weeds on the approach of winter. For some varieties two feet apart in the row may leave larger gaps than the runners can fill, but almost any of our commercial kinds will easily till up even larger vacancies. Such varieties as the Crescent will easily fill up intervals of three feet in rich soil. The runners should stand about six inches apart in the bed by the first of September.

Trimming and Setting the Plants. - The plants when dug should have all the dead leaves, pieces of runners and blossoms trimmed off, and if there is a considerable growth of leaves they too should be cut off. All flowers that appear the first year should be taken off. If the roots are large they are not readily planted, and it is customary to shorten them to about three inches. The way growth starts from these pruned roots is shown in Fig. 1. If a great mop of roots is planted in a bunch a part of them is very apt to rot. Perhaps as good a way as any to set the plants is with a spade. This requires two persons, generally a man and a boy, to do the work rapidly. After the land is marked out the man places the spade with the back side away from him, presses it about six inches into the moist earth, moves it from him and lifts it out. The boy takes up a plant, separates the roots, and puts them in the hole. The man puts the spade in the ground about four inches nearer him than he had it before and presses the soil against the plant. The boy

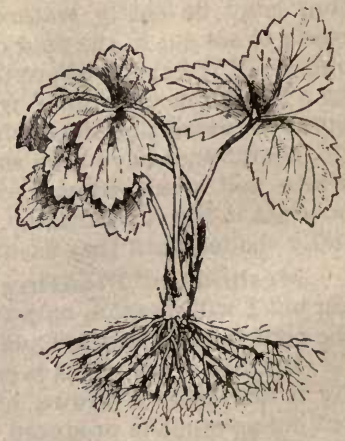

Fig. 1. Growth of prined roots. 
finishes the operation by firming the plant in the soil with $h$ is hands. As soon as the planting is done the cultivator should be started to loosen up the soil. Great care should be taken to keep the plants from getting dry when planting thern out.

Winter Protection.-Under whatever system the strawberry may be grown, it is benefited by being protected in winter by a mulch of sufflcient thickness to prevent frequent freezing and thawing, which is very injurious to the plants. Of course a covering of snow will answer the purpose, but it is not safe to trust to it. This mulch should consist of marsh hay, corn-stalks, straw, boughs, or any litter that does not lie too close and is free from weed seeds. It should be put on deep enough to cover the plants. Nothing is gained by covering very deep. This should be applied after the ground is frozen hard enough to bear up a team. In spring it should be drawn from over the plants into the intervals between the plants, where it will act to preserve the moisture during dry weather and to keep the fruit clean.

Avoiding Frosts.-It sometimes happels that the blossoms which appear about the middle of May, and are quite susceptible to frosts, are seriously injured of cold nights. They may often be protected when in this cri ical condition by taking the mulching from the rows and throwing it back again on the plants for a few days, or until the danger from frost is past. Hay or straw sprinkled with coal tar may be burned to windward of the bed of frosty nights, and will make dense, heavy clouds of smoke that wi!l afford protection. If the winter mulch is left on as late as it is safe to do so, which is until the new growth starts strongly, it will serve to retard the plants and they will not come into blossom until a week or so later than they otherwise would were the mulch removed early in the spring and not until the great danger of frost is pact. This latter method makes the crop late, but I think it the safest plan to follow. An ordinary frost seldom destroys the stamens, its damage being confined to the pistils, therefore the center or berry part of the flower turns black.

How to Continue Beds in Bearing.-Some growers prefer to fruit their strawberry beds but one season. I think it best to fruit the bed at least two seasons, provided it is in good condition when the first crop is gathered. I have often had the second crop on a strawberry bed better than the first, but generally it is not quite as good. The best plan to follow with an old strawberry bed is about as follows:

RENEWING STRAWBerRy BeDs.-There are sereral ways of renewing an old strawberry bed, but perhaps the following plan is as good as any: As soon as may be after the crop is gathered the bed is closely mowed and all the weeds and strawberry leaves are burned. A plow is then run on either side of the matted rows and all but about one foot in width of it is turned under. The furrow thus made is filled with fine rotted manure and the cultivator set 
going. The plants remaining are then thinned out with a hoe and special pains is taken to cut out all weeds and old or weak plants. This leaves the old bed clean and with plenty of manure close by, in which the old plants can make new roots. The plants soon send up new leaves which are much healthier than they would be were the old foliage allowed to remain, and if we have an ordinary season an abundance of runners will be sent out, and by winter the old bed will look nearly as vigorous as a new one.

This method of renewing the old bed has the merit of destroying all the diseased foliage, and to some extent also injurious insects. It is very important that the renewed bed be kept healthy by frequent cultivation and the destruction of any insects that may appear in order to have it do its best in fruiting the following season.

Sexuality of the Strawberry Blossom.-We have two classes of varieties of the strawberry, distinguished by their blossom. One class has perfect flowers, $i$. $e$, all its flowers have stamens and pistils (male and female organs). These can be planted alone without any other variety near, and will produce fruit. This

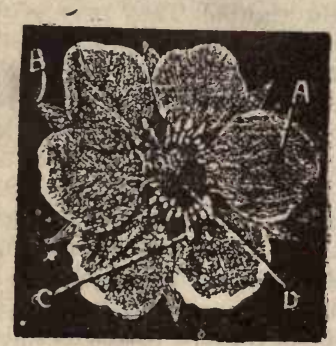

FIG. 2. Bi-sexual, or perfect flower of strawberry. $A$, petal; $B$, sepal; $C$, Stamens; $D$, pistils.

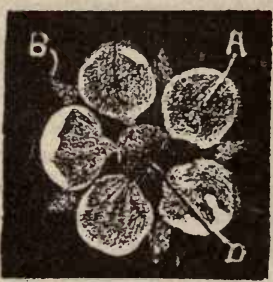

FI(i. 3. Pistillate or imperfect flower of strawberry. A, petal; $B$, sepal; $D$, pistils (notice the stamens are wanting.

class may be called bi-sexual (See Fig. 2). The other class has pistils (female organs), but does not have stamens, or has but very few of them. This class is ca'led pistillate (See Fig. 3). It is found in practice that the varieties with pistillate blossoms generally produce more fruit than those with bi-sexual flowers, consequently it is advantageous to raise as many of such k'nds as possible and as few of the others, but it is necessary to have some of the bi-sexual kinds near the pistillate kinds or no fruit is produced. Just the proportion that should exist between the bi-sexual and the pistillate kinds is a disputed point, but it is probably about one to three or four, depending upon the weather at the time of blossoming. It is safe to say that when pistillate kinds are used every third row should be of some bi-sexual kind, selected so that it will 
be in flower at the same time as the pistillate variety The neglect of this precaution is a constantly recurring source of disappointment. Some growers recommend that erery third plant in the row be of some bi-sexual kind. The objection to this way in practice is that the pistillate kinds, being often the strongest growers, may soon crowd out the weaker variety; and then, again, when this plan is followed the plants when taken up are so hopelessly mixed as to be worthless for setting a new bed.

Figure 2 shows the blossom of a bi-sexual or perfect flowering variety, and this differs from Fig. 3 chiefly in having between the petals and the pistils a ring of many stamens. This difference is plainly seen in flowers of the different kinds by any one who will take the pains to more than glance at them. It will be noticed that Fig. 2 is shown with six petals and Fig. 3 five petals. This is not a constant variation between the two kinds and is of no importance, but it is thus shown to call attention to the difference in the number of their petals in varieties, and it is not uncommon to find a strawberry blossom with seven petals, although the normal number is five. Different flowers on the same plant even may vary in number of their petals.

Dry Berries, "Nubbins."-Sometimes the berries fail to fill out evenly all over, or are small and mostly dry and hard or one sided. This probably results f,om the pistils, or a part of them, being injured by the frost, dry wind, or an unusually severe rain or hail, which, by destroying the delicate pistils prevents the formation of seeds and the development of the berry adjoining, for it has been conclusively proven that unless the seeds are perfected the fleshy part near them does not fill out. Somet'mes the blossoms are stung by a snout-beetle, then they hardly form berries at all.

Picking and Marketing. - If the berries are to be sold great care should be taken to have them carefully picked. Green berries are bad enough to have in a box, but, if they are to be shipped, over-ripe ones will cause much more trouble, for they are sure to decay before they reach their destination and to damage all the good fruit. On this account the beds should be picked clean every day in warm weather. The pickers will need careful .watching so as to be sure they do not put poor berries in the bottom of the boxes, and that they pick all the ripe berries so none will be left to get over-ripe. It is always desirable to pick fruit, that is to be shipped, in the cool of the day unless it should be wet.

Gift packages holding twenty-four boxes are almost universally used in this state. They cost about twenty cents per crate, including bcxes and cover. They are always made so there is room to heap up the boxes and to allow of a circulation of air through the boxes. A box holding little more than a dry measure quart when even full and nearly a liquid measure quart when heaped, is the size generally used. It is called the scant quart box.

- Diseases. -The strawberry is subject to several diseases, but only one is very serious. It is commonly called "Leaf Blight," 
"Rust" or "Sunburn," (Spharella fragarice). It is a minute parasitic plant which hives in the tissues of the leaves and stem. In the early spring small purple or red spots appear on the new leaves. About the time the plants are exhausted by fruiting, or perhaps before the fruit is fairly ripe, these spots increase rapidly in size, and in a few days what was a promising strawberry bed is dried up and worthless. Many varieties that are hardy otherwise have foliage that is susceptible to this disease, and some kinds should not be plant. ed unless some fungicide is used to protect them from it.

Our growers at present prefer to obviate the necessity of using fungicides by planting only those varieties that are very robust and

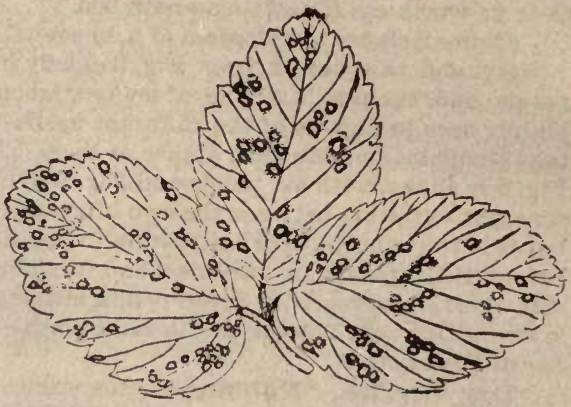
healthy. However, FIG. 4. Leaf of strawberry, marked by Leaf Blight, it may be desirable in its early stage (Sphatertla fragarice.)

to grow some varieties with weak foilage, such for instance as the Captain Jack, a fine bi-sexual kind that was formerly very healthy but of late years has frequently been ruined by blight. In such a case the newly set plants should be sprayed three or more times the first season, commencing as soon as the young plants are well established, and twice the following spring, with Bordeaux mixture or some other fungicide. To do this requires no more labor or expense than it does to spray for the potato bug the same number of times, and the grower will be well repaid in the increased crop. Highly cultivated plants are less liable to diseases than those that are neglected.

Bordeaux Mixture.-This is made by slacking two pounds of quick lime in 20 gallons of water in one barrel, and dissolving three pounds of sulphate of copper (blue vitriol) in two gallons of water in another bariel. A piece of coarse burlap is now put over the barrel containing the sulphate of copper, and the slacked lime and water is strained through it and the two compounds are well mixed together. It is now ready to use and should be applied with a spray rump. This is the same solution that is so successfully used to prevent blight and rot on potatoes, mildew on grapes, etc.

White Grab (Lachnosterna Sp.)-This is the common white grub found in sod land and in manure. It is the larvæ of a large beetle, and may be very disasterous when the plants are set on sod land, but is seldom if ever very injurious under other conditions.

Leaf Roller.-This insect is injurious in the larva stage. In feeding it folds up the leaves by drawing the edges together by 
silken threads and then eats out the soft parts. There are two broods of this insect during the year. The females deposit their eggs on the leaves where they soon hatch, and the worms commence their work. The second brood winters over in the pupa state in the ground near the plants.

REMEDY.-The larvæ are not easily reached with any insect1cide as they are nicely protected by the folded leaf. The first brood is rather difficult to destroy without injuring the fruit. Since the second brood does not appear until July they may be destroyed by mowing off and burning the foliage of the plants. Where there are but a few infected leaves they should be crushed in the hand, a few trials showing the best method of crushing the worm inside.

Shading the Strawberry Bed.-Some experiments recently made seem to indicate that the fruitfulness of strawberries may be increased by partially shading them, as shown in Fig. 5. While this might not be practical on a large scale, yet it is so very inexpensive that it could easily be tried in the home garden. It is suggested that such a screen, w.th a light wind-break near by, would

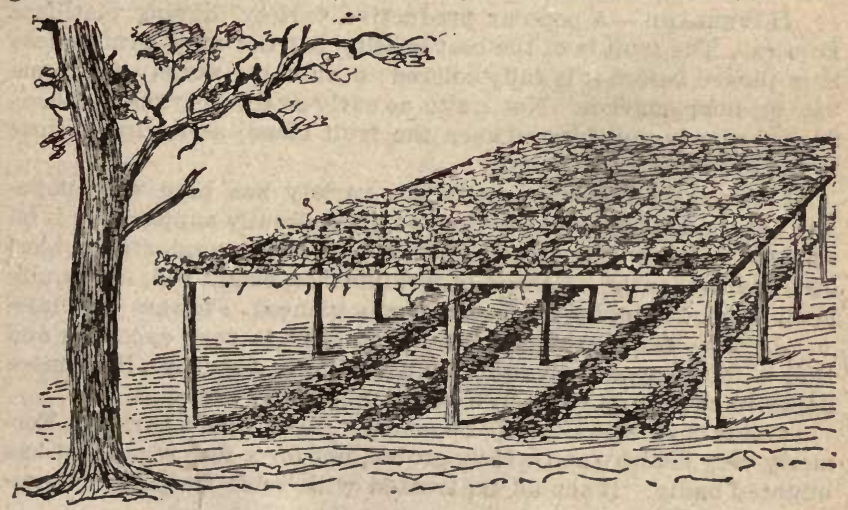

FIG. 5. Screen for shading strawberry bed.

prevent the pollen being blown away, or the flowers or plants from being seriously injured by frost, drying winds or hail. It will be remembered that generally the best fruit, and certainly the best late fruit of the strawberry, is found in the wild state in somewhat protected and shaded locations, and that in such places the plants are most vigorous and the foliage is seldom diseased. Many ways of making such a screen will suggest themselves to the reader, but it may be well to add that it should be at least six feet from the ground - to allow of a good circulation of air and room to cultivate -and covered with willow or other brush sufficient to keep out not more than one-half the sunlight. 
Varieties. - The varieties vary much in size, color, and quality of the fruit and vigor, productiveness and hardiness of the plants. The flowers also vary, as has been mentioned under the head of "sexuality of the flowers." There are now probably over a hundred varieties catalogued by nurserymen, and new varieties are brought out each year, but of the new kinds that we have tried probably not one in twenty-five has been worth the keeping. It is well not to pay a high price for plants. The new kithds, if good, are soon offered at reasonable figures. As a rule it is not necessary to pay over twenty-flve cents per dozen, or one dollar per hundred for plants. In quantities of flve hundred or more they can be bought at much less cost. About two hundred plants, if well set out and cared for, will give all the fruit needed by the ordinary family.

WARFIELD.-Probably the most popular berry grown. Blossoms, pistillate; plant healthy, a strong grower, producing a great quantity of runners, and is very fruitful. The fruit ripens very early, is of good size, dark red and firm, but not sweet or very large. A good variety to ship.

HAVERLAND.-A popular productive variety, having pistillate flowers. The fruit is of the best quality but not very firm, unless it is picked before it is fully colored; a valuable variety for home use or near market. Not quite as early as the Warfield. Needs special care in mulching to keep the fruit clean, as it ripens close to the ground. Very healthy.

Crescent.-For many years this variety has been very popular, but the Haverland and Warfield are generally supplanting it on account of their being more rroductive. Fairly productive, vigorous, healthy, early. Berries of medium size, bright red, firm, quite acid. A good shipping kind and largely planted. Flowers pistillate.

Jessie.-A bi-sexual variety. The fruit is rery excellent and it is a fairly good pollenizer for most kinds, but it is a little more liable to be injured when in blossom than many varieties.

CAPTAIN JACK.-Flowers bi-sexual. An excellent variety. Formerly very healthy and widely grown, but for a few years past has blighted badly. It should be treated with some fungicide to preserve the foliage.

BEDER WOOD.-An exceedingly promising bi-sexual variety that has not yet been widely tried.

MICHAEL's EARLY -A strong grower, producing lots of pollen, but rather inferior as a fruit producer. We think it one of the very best for producing pollen to fertilize other kinds. Very healthy. Bi-sexual flowers.

WILson.-One of the oldest varieties in cultivation, and where healthy is still a most excellent pollenizer. It is, however, somewhat fickle about its location.

Other varieties of considerable merit are-of pistillate kindsBubach, Princes, and Gandy, a very late variety, with bi-sexual flowers. 


CHAPTER II.

\section{RASPBERRIES AND BLACKBERRIES.}

OME species of the cultivated raspberry are found indigenous to almost every climate. Many species are very prolific of fine fruit in their wild state, and all of them improve rapidly under cultivation. It is an especially desirable fruit for temperate climates, where it is found at its best. There is a great difference in the adaptability of the different species as well as varieties to various climates, but there is no section of Minnesota where some kinds cannot be safely and surely grown if proper care be used in planting and cultivating. It is a surer crop than the strawberry, and the plantations of it will last indefinitely, seldom needing renewing more than once in ten years, and frequently producing abundantly over a longer period.

Species.-There are four species to which our cultivated kinds belong, and they quite readily bybridize together. They all have perennial roots and biennial canes; $i$. e., the canes grow one year and the next mature fruit and die, so that there are always two sets of canes to each plant during the growing season.

(1) Rubus strigosus. This is the red raspberry of our woods; there are, however, some varieties of it that have yellow fruit. Plants belonging to this class increase by suckers, which they generally produce abundantly from all the surface roots. All of the most desirable red raspberries in cultivation, with possibly one exception, belong to this class.

(2) Rubus Ideus. European raspberry. In form and color of fruit and method of propagation this resembles the preceding, but differe from it botanically in several minor points. Varieties of this are not generally as well adapted to the climatic conditions of this state as our native species.

(3) Rubus neglectus. There is much difference of opinion in regard to the plants grouped under this species. Some of the best botanist consider the varieties generally put here to be hybrids between $R$. Strigosus and $R$. Occidentalis. The fruit from this class is often of a purplish color, but is sometimes yellow, and the plants often increase both by suckers and by tip-layers.

(4) Rubus Occidentalis. Black-cap, or thimbleberry. A native species, very distinct from one and two; increasing by layers, $i . e .$, the tips of the new growth bend to the ground and take root 
the latter part of the summer. They seldom produce suckers. The fruit is generally black, but there are a few varieties with yellowish fruit.

All the cultivated raspberries are commonly referred to as:

SUCKERING Kinds; those that increase by suckers, which comprise chiefly varieties belonging to the three species first named.

TiP-ROOTING KINDS; those that increase by tip layers, which chiefly comprise varieties belonging to $R$. Occidentalis, but a few that belong to $R$. neglectus.

Propagation.-The raspberry may be propagated by the following methods:

BY SEed. - All the cultivated kinds may be grown from seed, but plants from seed are not "true," $i$. e., are not like the plants from which they came, and it is only an occasional seedling that is nearly as good as any of the varieties commonly cultivated. To raise seedlings the "dead" ripe fruit should be crushed in a small amount of dry sand, and the whole sown at once in a light moist soil, somewhat shaded. The seed will seldom germinate until the following spring, when after the plants are large enough to handle they may, if too thick in the seed beds, be set out in another bed to grow the first season, or if not crowded be left to grow where they are. The plants should be taken up in the fall, "heeled in," and planted again the following spring, when they will bear fruit the following (third) year. Another way is to sow the seed as soon as obtained in small boxes, and cover them lightly with leaves or litter. In February bring the boxes into a greenhouse, transplant to other boxes as soon as the seedlings have thelr third leaves formed, and plant permanently outdoors as soon as large enough and the weather permits; by this system some fruit is generaily obtained the second year.

Bx Root Cettings. - Most of the varieties of raspberries coming under the first three species mentioned produce sprouts from the roots (Fig. 6), and these are generally used to start new plantations, but when there is a shortage for this purpose it is customary to grow plants of the suckering kinds from root cuttings, which may be made as follows: In the autumn after the plants have stopped growing the roots are taken up, cut into pieces two or three inches long and put in boxes, with alternate layers of sand or loam. The boxes are then

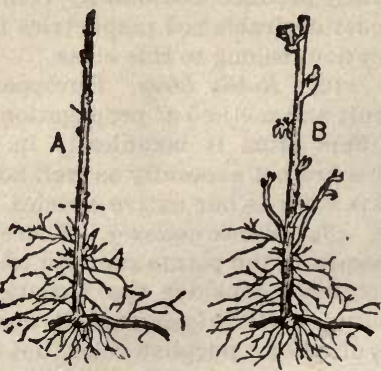

FTG. 6. Raspberry sets of the suciering class. A, before buds have started. B, after buds have started. The stem should be cut off at the cross line. buried in some well drained spot until the land is fit to work in the 
spring, when the roots should show a callous on the cut ends. The roots are then planted three or four inches apart in furrows and covered about two inches deep in rich soil. By the end of the season they will have made plants large enough to set out (Fig. 6).

This plan for growing plants from root cuttings may be greatly changed in detail, but the general plan is the same. It is always best to make up the root cuttings in the fall, but cuttings from strong growing kinds do nearly as well made up in the spring. The cuttings are generally made with a sharp knife or a pair of pruning shears, but nearly equally good results may be had by cutting the roots in a hay cutter.

By LAYERs. - The Black-cap and some other kinds grow most readily from layers. The tips of the new growth reach the ground about the latter part of August or first of September, and readily make new plants if held in place (Fig. 7). These tips should be cov-

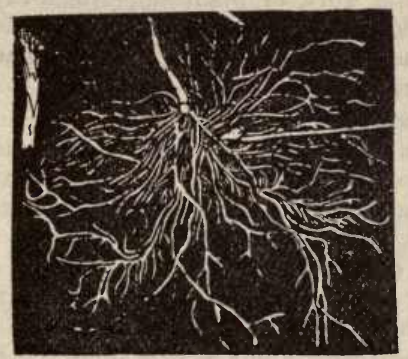

ered with a spadeful of soil, or better, be inserted three or four inches into a hole made by pushing a spade in the ground. They will be well rooted in three weeks. These rooted layers will be found to winter over most safely if allowed to remain undisturbed until spring, but should have a light mulch over them during winter. They may be wintered over if dug and very carefully heeled in, or kept in

Fig. 7. "Cap" raspberry set or plant of carefully heeled in, or kept in
one season s growth. The straight line a cold cellar, but the plan recshoves the bud that will start into growth ommended should be followed in the spring and form the new plant. when practicable. It is not considered good policy to plant the layers in the fall as they are very liable to winter injury when disturbed in autumn. In digging the layers about ten inches of the cane should be cut off with the roots to facilitate handling ( $F i g .7$ ). It is generally believed that unprotected plants are much hardier when the layers remain attached to the plant during winter than they are if the layers are cut off in the fall.

Location and Soil.-The common varieties of the raspberry succeed admirably in any good soil; but the suckering class, which includes chiefly the red varieties, produce rather better than the black-caps in moist, heavy loam, and the latter do best in a sandy loam. A northern slope is generally better than a southerly one as it is less liable to injury from drouth, which frequently shortens the fruiting season in bad situations; but it is well known that some varieties withstand dry weather and other climatic troubles far better than others of the same species. 
Manure and Preparation of Land.-Ail varieties need high cultivation. The land should be heavily manured and thoroughly plowed and brougint into the best condition for corn or other gross feeding crop. The best fertilizer is well rotted barnyard manure. Raspberries, especially the black-cap kinds, will produce very well even on quite poor soil, but rich land and thorough cultivation is necessary for the best success with any variety.

Time of Planting.-The suckering kinds may be planted in autumn or spring with safety. When the work is done in the autumn great care should be taken to firm the soil around the roots, and a forkful of mulch over each hill is a great protection against winter injury. Many growers prefer to set in autumn, as at that season they can give the work more careful attention than in the spring. Then again the new sprouts from sets (suckers) start very early, and if the work is delayed in the spring they are often broken off or injured in the work of planting. Black-caps and other tip-rooting kinds should never be set in the fall, as they are very liable to be winter-killed if moved at that season. They should always be set in the spring.

Selection of Plants. - Since the canes are biennial there is no such thing as two or three-year-old plants, as with trees, when we refer to the stems; but the roots may be of any age, as they are perennial. Plants of one season's growth are best to begin with. Sucker plants are generally best with the varieties increasing in that way; but plants from rost cuttings may be just as good, or even better, when well grown: The old stools may be broken up and the plants set out, but such sets have few fibrous roots and often start slowly; with the tip-rooting kinds plants obtained by breaking up the old stools are not so good as those from the suckering kinds obtained the same way, and should not be used when aroidable, as they are very apt to fail even with the best of care. It is important to use only vigorous sets taken from perfectly healthy stock. Old plantations of raspberries frequently become diseased and plants from them are often worthless, consequently care should be exercised in buying plants.

Planting and Cultivation.-After the land is thoroughly prepared the plants should be set out in rows seven feet apart and at three foot intervals in the rows, putting two plants at a place. The distance between the rows may be lessened to five feet if more space is not available and the weaker growing kinds are planted, but the greater distance admits of cultivation even when the bushes are loaded with fruit. It allows sunlight to readily reach the plants and is most satisfactory every way, and for profit they should never be set any nearer; while for some of the strongest grcwing varieties the hills should not be nearer than five feet in the row. At the time of planting the canes should be cut off close to the ground and no fruit allowed to form the first season.

A good way to plant is to mark out the land the three-foot way and then furrow out where the rows are to come. Set the plants 
in the furrows, covering them temporarily with the feet, and afterwards more carefully with a hoe, firming them in with the feet at the same time. The rows should preferably run north and south, for planted in this way the fruit is shaded by the new growth during the hottest part of the day during the period of ripening.

Depte to Plant.-Black-cap raspberry plants should be set about the same depth in the soil as they naturally grew. The roots should be carefully spread and the soil well tirmed over them. The suckering kinds should be planted a little deeper than they naturally grew and be well firmed in.

Cultivation. - The soil should be kept loose with a horse cultivator and the rows free from weeds. If the land gets hard the onehorse plow may be used, but the land should be kept flat and as free from ridges as possible. Frequent cultivation, especially in a dry time, is important.

Prenixg Axd ThiNisg.-Not more than two shoots should be permitted to grow from each root the first year, and these should be pinchr $d$ off when eighteen inches high to encourage the growth of lateral branches, for it has been conclusively proven that raspber. ries fruit more heavily on the laterals than on the main cane. The

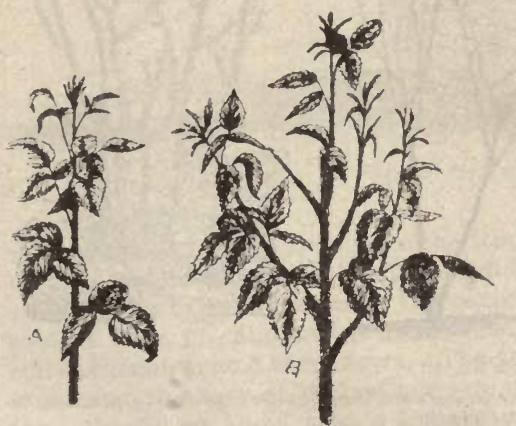

FIG. 8. A, ynung black raspberry cane as it appears before pinching. $B$, the same $a$ short time ufter being pinched. showing the way growth starts from the buds. second and succeeding years the suckering kinds will produce a lot of sprouts all around the hill; four or fire of those nearest the hill should be allowed to grow and the rest treated as weeds. If a great lot of these suckers are allowed to remain but little fruit will be produced. Black-cap raspberries will th's year send up a half dozen or so of sprouts at the base of the old plants, and enough of these should be removed to allow the remainder to properly develop. All these sprouts should be pinched once when from twelve to eighteen inches high (Fig. 8-9). As soon as the fruit has been gathered the old canes which have borne fruit the current y ear should be cut out and destroyed. (Fig. 10.) In the spring the suckering kinds need no pruning, but the lateral canes of the Black-cap varieties should be shortened back to twelve or fifteen inches (Fig. 11). This is very important, as the branches of this kind are so slender that they will bend to the ground and break under the weight of fruit unless sererely pruned, or they may set more fruit than they can mature and the whole be lost. When pruned in this manner the 
fruit will be much larger and the plant will yield as much fruit as if all the canes were left their whole length.

MuLchING.-The first year no mulching is needed; but the second season, as early as the middle of June, the rows should be mulched for two feet on each side with hay, straw or litter, or with what is better still, green clover cut when in blossom and put on two inches deep. The latter is especially desirable because it lies close, and as it rots in one season and is very rich in plant food it makes a good manure. This material keeps the land moist, the berries clean, and kills out weeds. After putting on the mulch as recommended there will still be a space two and a half feet wide between the rows where the cultivator should be run to keep the soil loose. Too much stress can hardly be laid upon the importance of mulching this fruit. It frequently makes a difference between a good profit and a big loss.

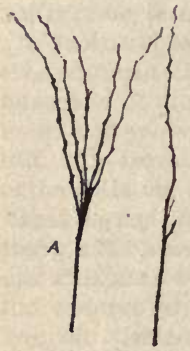

FiG. 9 .

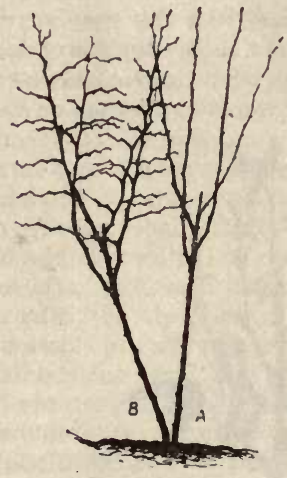

FIi. 10

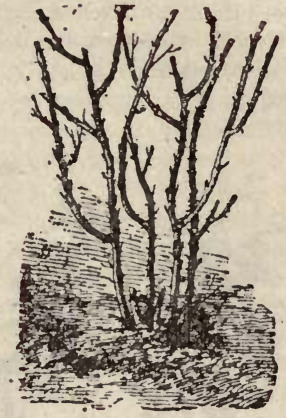

FIG. 11

Fig. 9. A, Red raspberry cane in autumn that has been properly pinihed in summer. B, Cane not pinched.

Fig. 10. $A$, The fully grown cane of the current season's growth which wall fruit next season. B, Cane two seasons old, which having fruited, is to be cut away.

FIG. 10. Spring pruned Biack-black raspberry plant.

Support.-It is desirable in this climate to have the canes supported in some manner. In milder sections, where winter protection is not necessary, the bushes may be so frequently pinched as to make them form little trees that support themselves; but this kind of treatment is not desirable where the plants have to be covered in winter, as it makes them so very stocky they cannot be easily laid down. A very good support for rasperries and blackberries is made by running a No. 12 galvanized iron wire on each side of the bushes attached to a good solid post at each end of the row. This wire should rest on nails driven in stakes set twentyfive feet apart. Such a support permits the plants to move gently. 
in the wind but not sufficiently to break them by its violence. It keeps the fruit off the ground and is cheap and convenient.

Winter Protection.-As a rule it is not safe to allow any known variety of raspberries to go through the winters of this section without some kind of protection, not that they will always kill to the snow line if not protected, but because covering them involves no great expense, makes them almost a sure crop, and the covered plants seem to have more vigor than those left exposed. There are, however, locations near some of the larger lakes, or where surrounded by forests, that are so very favorable that such varieties as the Turner, Souhegan, and even the Cuthbert, are not injured when left unprotected in winter.

The bushes should be covered late in autumn before the ground freezes hard and should not be handled when there is any frost in

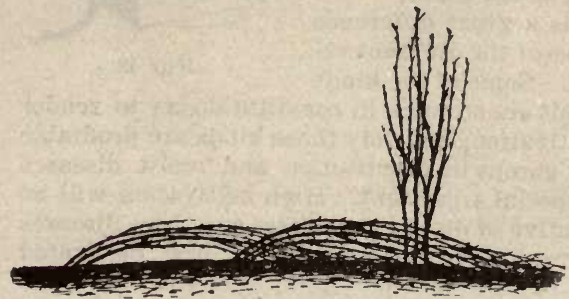

FIG. 12. Canes laid down for winter but not yet cover'ed. the canes. The best covering is fresh earth. In laying them down commence at the north end of the row, remove the soil from the north side of the hill, about four inches deep, with a garden fork; gather the branches together with a two-tined fork, press gently to the north, at the same time place the foot firmly on the base of the hill and press hard, bending the bush in the root as much as possible, and as little as may be in the canes, until cearly flat on the ground (Fig. 12), and hold it there until second man covers with soil sufficient to hold them down. The top of each succeeding hill will lie at the base of its predecessor, making a continuous covering. It will be found that a little of mulch put on the canes first after laying them down will hold the soil rut on, and much less will be required than if no mulch,is used. After laying them all down turn a furrow against each side of the rows, covering as much as possible, and draw a little over any canes that may be left exposed. It is only necessary to use soil enough to barely cover the canes. There are some of the strong growing varieties, such as the Gregg, that en rich land are very difficult to cover. With them it:will do very well to bend as nearly to the ground as is safe and cover the tops with enough soil to hold them in place. While it would be better to cover them all if it were practicable, yet treated in this way enough snow will generally lodge in the canes to cover them, and if this is supplemented with a light covering of coarse litter or straw so much the better. If mice are numerous they must be poisoned, or they may eat the canes under the mulch. 
Lifting Canes in Spring.-In the spring use a round.tined fork; carefully remove the earth and raise the plants to a slanting position. It is found that left in this position the fruiting canes are shaded by the new growth and are not so crowded as when raised up straight.

A Convenient Box Holdex.-Thayer's berry-pickers' box carrier (see Fig. 13) for use in picking raspberries and blackberries, is made of tin of a size to easily hold a berry box. It has straps to fasten around the waist of the picker, and a slatted bottom, so the berry box may be easily pushed up from the under side when taken out. Its chief advantage is that it leaves both hands of the piclier free to gather fruit and keeps dirt out of the boxes.

Diseases. - There is a great difference in the liability to diseases of the different varieties of the raspberry. Some of the kinds

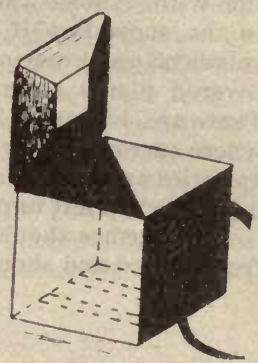

FIG. 13. producing the finest fruit are so weak in constitution as to render them valueless for cultivation, and only those kinds are profitable which are strong and vigorous in constitution and resist diseases without recourse to special treatment. High cultivation will be found the best preventive of disease, but there are three diseases that are occasionally very injurious even in the best cultivated plantations.

(1) LEAF CuRL-This name is indicative of one of the early stages of the disease. The leaves curl up, and though they may remain green all through the season the plants make a poor, weak growth. The fruit is dull in color, small in size, and rather bitter in taste. Later the plants kill out, and any healthy sets with which they may be replaced soon succumb to the trouble. This disease spreads very slowly, and, as a rule, there are only a few infected spots in a plantation, which slowly increase in size from

- year to year. The spread of the disease may be prevented to a great extent by pulling and burning the diseased plants as fast as they appear. In setting out a new plantation use only land which has not been in raspberries for several years, and to take great care to have young, healthy sets. Do not accept plants from a weak plantation on any account.

(2) Red Orange Rust (Cacoma luminatum). - This is most hurtful to the black cap raspberries, though it frequently injures other kinds. It produces a weak appearance in the canes and foliage, and in the latter part of the summer the underside of the foliage becomes completely covered with a thick coating of brilliant orange colored spores, which easily rub off. One soon comes to know the plants that are diseased even before the spores appear, and they should be pulled and burned at once. This is especially necessary with the black-cap varieties; but even with these, if the affected 


plants are destroyed, the disease may generally be kept in check until a new plantation can be well started, and sometimes assiduous attention to pulling and burning results in stamping out the disease.

(3) Anthractose, or Cane-Rust-Also known as the raspberry cane-rust. It manifests itself by weakening the growth and causing the bark of the canes to become marked with many white or grayish, flattened or depressed spots, bordered by a ring of purple; some of these spots may be one-third of an inch in diameter. This disease seldom does serious injury to any but cap varieties of the raspberry, and it is only occasionally noticed to any extent in this state, and then not as being very hurtful. In some of the eastern states it is so abundant as to almost prohibit the growing of cap rarieties.

The treatment for this disease consists in burning all the infected canes and in applying Bordeaux mixture to the new growth occasionally during the growing season, commencing early.

Insects.-The rasberry is seriously injured by but few insects. The most common are the following:

RaspberRy Flar-headed Bokek (Agrilus rufieollis) Fig. 14. The perfect form of this insect is a beetle which lays its eggs in the growing canes some time during the summer. Where the eggs are

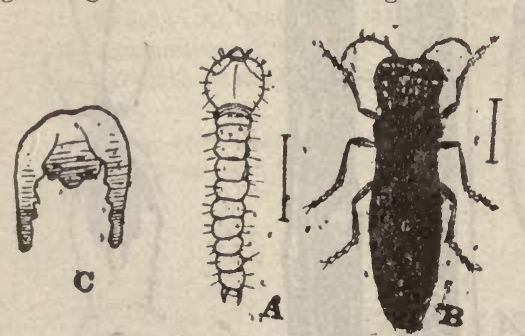

Fig. 14.-Raspberry Cane-borer A, larva. $B$, malure insect. $C$, Iforns at extremity of abdomen of larva. laid peculiar gall-like swellings may occur (Fig. 15), having many rough slits in them; but this is not always the case, for sometimes canes may be killed by the insect and no swellings at all appear on the canes. The eggs hatch into little yellowish-white larvæ, having a flattened body, brown jaws, and a tail furnished with two dark-brown horns. One swelling may contain many larvæe. When full-grown the larvie is from one-half to threefourths of an inch long, and by burrowing in the wood frequently girdles the canes. The perfect beetles emerge about the time the plants are in full blossom. They have a brilliant copper-colored head and thorax, and the body and hard wings are velvety black.

As the insects winter over in the canes they may be destroyed by cutting and burning all the infested wood some time during the winter.

Snowy Tree Cricket (Oecanthus nivens). Fig. 16. This insect does not feed on the raspberry plant in any way, but it is injurious on account of its peculiar habit of puncturing the canes with lines of little holes in which to deposit eggs. If this work does not kill 
the canes it so weakens them that when they start in the spring they are very apt to break off as soon as the foliage is expanded. The eggs, which are laid in autumn, are yellow and about oneeighth of an inch long. They are not readily seen when laid, but by the latter part of winter the infested canes take on an unhealthy appearance by which they may be readily located. They should then be cut out and burned. This insect feeds on leaf lice and is thus beneficial to some extent, but it causes so much injury by lay. ing its eggs in grape and other p!ants with pithy wood, as well as the raspberry, that it should be destroyed as nearly as possible.

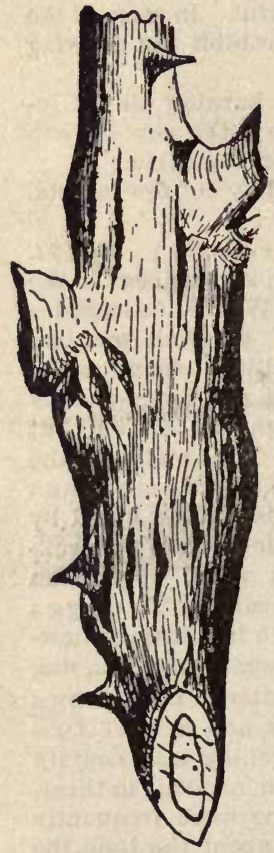

FIG. 15.
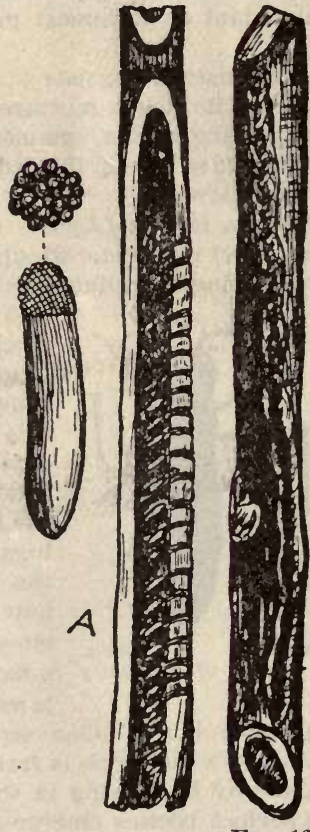

FIG. 16.

FIG. 15 -Gall-like swelling resulting from work of raspberry cane-borer.

FIG. 16-Snow Tree Crickst. A. Shows its melhod of work in the canes; an egg enlarged with its end still further enlarged. $B$. The insect that does the mischief.

Varieties.-There are many varieties of the raspberry offered by various nurserymen, but the following have been well tested and are the most desirable, yet there are many other good kinds. About fifty hills of raspberries will be found sufficient for the ordinary family garden, and it will be most satisfactory to have them 
divided so as to give one-half of red and the other of the black-cap kinds.

Suckering Kinds. Cuthbert-A strong growing, hardy, productive kind, having large, red fruit of good quality. The most popular of the late varleties.

Marlboro-The most popular early red berry for marketing; of fairly vigorous growth, hardy, and very productive. The fruit is very large, bright-red and firm; however, it is of rather inferior quality. It needs the highest cultivation.

Golden Queen-Like the Cuthbert, but of a yellow color. The best yellow fruited kind.

Turner-The best known and the hardiest of the red kinds. Plant of strong, vigorous, healthy growth, and very productive. Fruit sweet, of fair size, though somewhat soft. Not popular for marketing. Other valuable kinds of this class are Hansell, Clark and Reliance.

TIP-Rooting Kinds. Schaeffer's Culossal-Very productive, but its dull purple color makes it a poor kind for marketing. Valuable for the home garden and for canning.

Ohio-Not as early as the Souhegan, but the most popular of the early black-caps for general planting.

Nemeha-A beautiful large, very productive, strong growing kind, of medium quality and latest in ripening. It is now the most popular late black-cap raspberry wtih those who are acquainted with it.

Other good kinds of th's class are Souhegan, Gregg, Older and Johnson's Sweet. There are no good yellow varieties belonging to this class.

\section{BLACKBERRIES.}

The blacirberry is nearly allied-botanically-to the raspberry. There are two species of it cultivated, and both of them are natives of Minnesota and other northern states.

HigH-BUSH BLACKBERRY (Rubus villosus). To this species belong the kinds generally cultivated. The fruit, almost without exception, is black; but there are varieties with whitish or red fruit. This specie suckers freely and may be readily increased by root cuttings.

LOW-BUSH BLACKBeRRY OR DEWBERRY (Rubus Canadensis). The fruit of this resembles the above, but the plant is vine-like and traiis on the ground. It is propagated by layering the growing canes, which take root very readily. Varieties of this species are not generally cultivated with much success, but in some locations they fruit abundantly. 
The blackberry well repays careful cultivation. It requires the same soil and methods for planting, summer pinching, mulching and winter protection as the red raspberry. It should always be protected in winter. In the spring, however, the plants should not be pruned until the flower buds can be plainly seen, when, if in too great abundance, a part of the canes may be pruned enough to thin the fruit. (Fig. 17.) Never trim blackberries until the flower buds can be seen, for it often happens that the flower buds which are formed the year preceding that when fruit is produced are near the ends of the canes, and in pruning all of them are cut off. This is a frequent cause of failure with blackberries.

The insects and diseases affecting the blackberry are nearly the

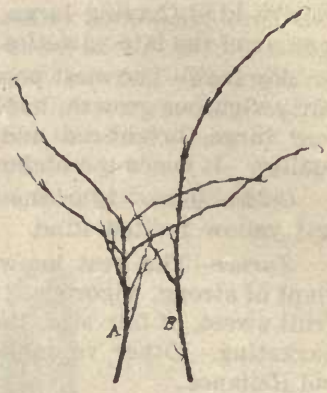

FIG. 17.-A, Blackberry cane properly pinched. B, Blackberry cane grown without summer pinching.

same as those injuring the raspberry, and are subject to the same remedies.

Varieties.-There are only a few varieties of special interest to planters in this state. About twenty-five hills of blackberries will be found sufficient to supply the ordinary family. They are as follows:

Ancient Briton.-This is probably the most valuable for general planting of any blackberry grown. The plant is hardy, healthy and productive; the fruit is large, sweet and of fine quality. The variety next described is often substituted by dealers for this variety.

SXYDER.-In some sections, generally on clayey land, this variety is most highly esteemed. It is very early, hardy, productive, and of good quality.

Dewberries.-The Lucretia and Windom are the best known varieties of dewberries. They seem to do best on sandy loam, but while some growers are very successful with them, others in different locations, who appear to take the best of care of them, fail most completely. Where they do well they are very desirable, as they produce their fruit earlier in the season than the tall kinds. As the vines lie on the ground they should be heavily mulched at. fruiting time to protect the fruit from dirt, as well as the roots from dry weather. 
CHAPTER III.

\section{CURRANTS AND GOOSEBERRIES.}

THE currant will grow and fruit abundantly in almost any soil - 0 r situation in the Northern States if given good cultivation; and even when it has but little care it is still very sure to produce a fair crop. However, no cultivated plant responds more promptly and generously to manuring and careful attention. The acid fruit in any of the various ways in which it is used is healtby and refreshing. It is not so universally esteemed as the strawberry, yet it is used in immense quantities each year, and first-class fruit carefully marketed generally pays the grower a good profit. No fruit is more satisfactory in the home gârden. A currant bush once planted will continue to bear fruit for an indefinite period, often for thirty years. There are very many species of currants, but our cultivated kinds belong to the following:

(1) Red Currant (Ribes rubrum). Native of the Northern States and Canada, Northern Europe and Asia. The European form of this species is the parent of all the red and white varieties in cultivation.

(2) Black CuRrant (Ribes Negrum). A vigorous, growing plant; native of Northern Europe and Siberia. The fruit is black and all parts of the plant has a strong peculiar odor, which to many people is unpleasant until they become accustomed to it. The fruit is grown only in quite a limited way. In many markets there is no demand for it, while in others it brings a higher price than the common currant. It is easily grown. Valued medicinally for throat troubles.

(3) Missouri or Flowering Currant (Ribes Aureum). A vigorous plant; native of Mississippi Valley; having beautiful, sweetscented yellow flowers early in the spring. It is much cultivated for ornamental purposes. Fruit large, purplish black and rather astringent. A few varieties of this species have recently been introduced as fruit plants, but none of them have proved sufficiently valuable to warrant their extensive cultivation. 
Propagation.-The currant does not come true from seed. The named varieties are grown from layers, cuttings, or divisions.

SEedLINGS are easily raised if treated the same as recommended for raspberry seedlings, but rather more care must be taken with its seed than with that of the raspberry as it germinates very quickly in the spring, and if moved after growth has started it often fails to grow. On this account the seed should be sown in the fall where it is to grow the following year. Or if sown in boxes they should be frozen until February or March, when they may be put in a greenhouse or hotbed. But very few seedlings are of any value, and the growing of them is seldom attempted.

Cutrings are very easily rooted and varieties are almost universally grown from them. They may be taken off at almost any time while the plant is dormant, and wood of almost any age or size will root if carefully handled, but the following method is generally very certain to bring good results:

As soon as the leaves have fallen-which may be in the latter part of August or first of September-the young wood (rrowth of the current season) is cut into pieces about seven inches long. They are then at once set out in rich, well drained soll four inches apart, in rows three feet apart. Only about one inch of the cutting should be above ground, and great care should be taken to very firmly pack the earth around the bottom of the cuttings. When thus treated they will have calloused and made some small roots (as shown in Fig. 18) before the ground freezes, and will start vigorously the following spring. The cuttings should remain as planted for at least one, or perhaps two years. If the land is in good condition they will be ready to set out when one year old, but can remain where planted for several seasons if well cultivated. If wood is scarce the cuttings may be shorter than recommended, but in such a case more care will be required to ensure that they do not dry out in the soil. Sometimes the cuttings may consist of a single bud each, and may be sown like beans in a furrow, but much experience is required to be successful with them when made so very small.

LAYERS may be made at any time during the growing season, but preferably in the spring or

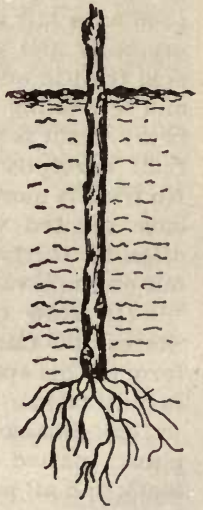

Fig. 18-Currant cutting planted in August showing the roots as they appear on the approach of winter. early summer, as they will then be well rooted by autumn. They consist simply of branches which have been covered with earth and have become rooted. After becoming well rooted they are separated from the old plant. The way in which they are made is shown in Fig. 19. The branches are rather surer to root if the bark and wood is cut or broken a little, or if treated as in Fig. 20, but most varieties root very easily without this trouble. The cur- 
rant may be increased by dividing the old bushes, however plants so made generally have but few very hard roots and are slow to start into vigorous growth.

Soil and Planting.-The currant will grow in almost any kind of land, and on that which will raise a fair corn crop it will

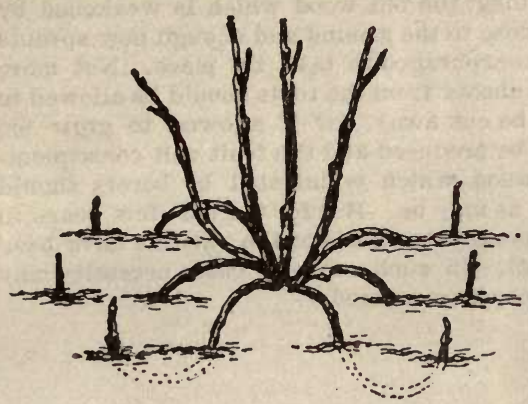

Fic 19.

Currant bush with six of its stems layered. give good returns, but the soil cannot be too rich or the cultivation too constant for the best crops of fruit. Plants may be set out in the fall or spring with good results. If set in a u um each plant should be banked up with about two spadesful of soil. They should be put tive or six feet apart each way, and for the varietles most generally grown six is better than five feet. One plant is enough for a hill, and those that are young and thrifty are better than older ones. Where practicable they should be planted so as to allow of cultivation both ways. They should not be set along a fence or border, as in such places they are difficult to cultivate. The land should be plowed lightly with a one-horse plow early in the spring, and the cultivator started soon afterward. While the plants are in fruit, cultivation will have to be suspended, as the weight of the berries will bend the branches so that they will be in the way and liable to injury. As soon as the crop is gathered the working of the land should be again commenced and continued until the middle of August, after which there is no need of it.

Mulching.-Good crops of currants may be grown without cultivation provided the land is heavily mulched, and in somewhat dry locations they are more surely grown on this plan than on any other. The mulch may consist of straw litter, coal ashes, hard wood sawdust, or similar material. If ashes or sawdust is used it should not be mixed with the soil but kept on the surface. It is often a good plan to mulch near the plants and cultivate in the center of the rows. Ashes or sawdust used for this purpose will keep down the weeds near the plants and do away with the neces. sity of hand cultivating. Pine sawdust is not as good for this pur. pose as that from the hard woods, but may be safely used if kept on the surface of the land and not mixed with it. Partially rotted sawdust is much to be preferred to that which is fresh.

Pruning.-The rurrant is improvet by some pruning eack year. This may be done at almost any season, but preferably ir 
August. To do this work properly it should be understood that but very little fruit is borne on the wood of the preceding season's growth, and that the buds which produce the greatest amount of fruit are on wood in its third season of growth or older. The fruit buds are formed late in summer and open early in the following growing season. In pruning, the old wood which is weakened by age, should be cut out close to the ground and enough new sprouts from the roots should be encouraged to take its place. Not more than from four to six shoots from the roots should be allowed to remain; the rest shoula be cut away, for if allowed to grow too much bearing wood will be produced and the fruit will consequently be very small. The wood which is infested by borers should also be cut out as nearly as may be. But for the past few years in some sections of Minnesota all the shoots of the currant have been infested with this insect. In such extreme cases necessity may compel the leaving of those least injured.

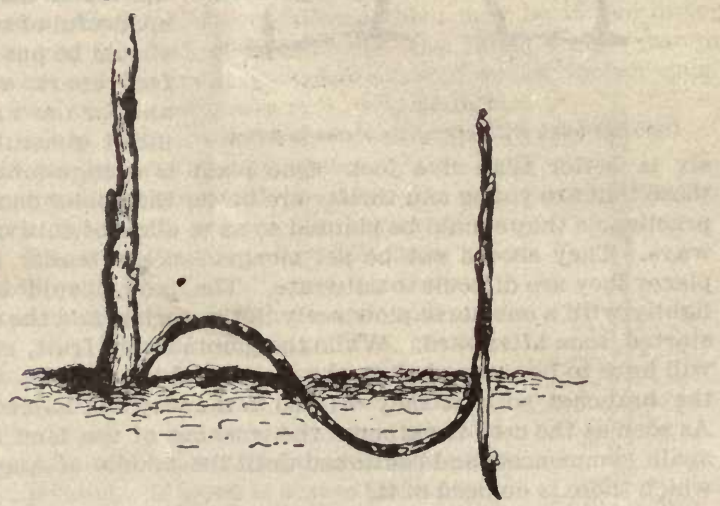

FIG. 20.-Currant layer split before layering to encourage ine formation of roots.

Tree Currants are frequently advertised as being very desirable and are often sold at a much higher price than commoner currants; while in fact they are our common currants pruned so as to make them take on a tree-like form. They appear very pretty while growing, but having only one stem the first borer that attacks it destroys the plant. To make plants take on this tree-form all but one upper bud is rubbed off the cuttings when they are set out. The remaining bud pushes up a straight shoot, which is allowed to branch at about a foot from the ground and to make a miniature tree. Such plants seldom send up sprouts, so the stem cannot be renewed. The common red currant is sometimes grafted on the Ribes aureum, but such plants are open to the same objections as other tree currants, and are only valuable as curiosities. 


Winter Protection.-The Red Dutch and a few other very excellent varieties are perfectly hardy in almost any soil or situation, but some of the kinds producing the largest fruit are occasionally injured in severe locations in winter. They may, however, be easily protected by covering them with earth, but if so treated they will need to be mulched or to have some support to keep the fruit off the ground, as the canes will not straighten up well in the spring after being bent down all winter. Another way of giving some protection is to tie the stems together in autumn with a string or willow withes. This is very desirable where the snow drifts over the plants, as it prevents their being broken by it when it settles in the spring and more protection is afforded by this treatment than is generally supposed.

Marketing.-It is customary to market the currant in baskets holding about six or eight pounds, but sometimes quart boxes and other packages are usf $d$ for this purpose. One must study the local mal ket to learn which package is the best to use. This fruit is generally sold by the pound. Unlike the raspberries and strawberries it will remain in good condition on the plants for some little time after getting rıpe, but it does not ship as well if very ripe as when it is a little green. The fruit makes the firmest jelly before it gets fully ripe, and on this account it is sometimes most profitable to market the crop when the berries at the ends of the bunches are still quite green.

Insects.-The CURrant Worm (Nrmatus ventricosus) is the most troublesome insect that attacks this plant. The female lays

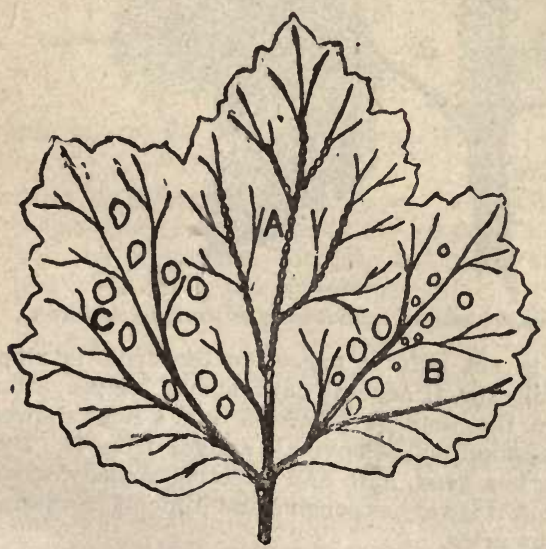

FIG. 21.-A, Eggs of currant worm on the vines on the under side of the leaf'. $C$ 'and $B$, Holes made by the young worms when they first commence to feed shortly after coming from egg. her eggs in rows on the veins on the under side of the leaves (as shown in Fig. 21) quite early in the season. They are white in color and about one-twentieth of an inch long. These eggs hatch in about ten days. The young worms feed in companles, at first eating small holes in the leaves as shown at $A, B$ and $C$ in Fig. 21, but later on they destroy all the green tissue in the leaf and then spread in ail directions over the bush eating th 
foliage. They will frequently strip a bush of its leaves in a few day's time if left to themselves. Figure 22 shows the worms at work in the latter stage of their growth. When full grown they are three quarters of an inch long. There are two broods of these worms; the first appearing before or about the time the fruit is ripe, and the second two or three weeks later. The mature insect is a fly somewhat resembling the housefly (Fig. 23).

Remedy.-Powdered hellebore mixed with its bulk of flour may be dusted on the plants when the follage is wet, or it may be use? at the rate of one ounce of powdered hellebore to a gallon of wa' yr and be sprayed on the foliage. Used in either way it is a ver $=$ cheap, effective and easily applied remedy. But hellebore is

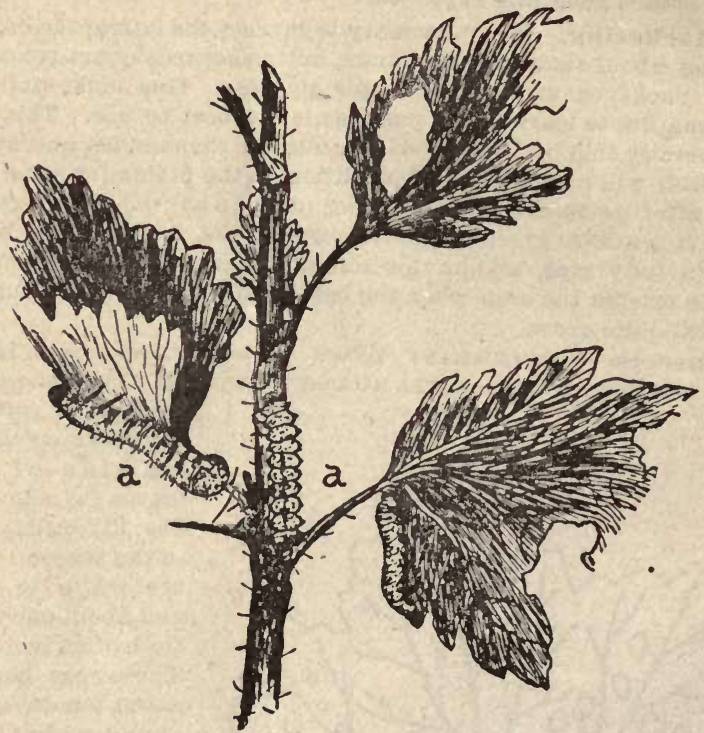

FIG. 22.-Currant worms (Nematus ventricosus) a! work on the leaves.

quite poisonous and is not safe to use when the fruit is ripe, although no danger will exist if several days should elapse after the application before the fruit is gathered, and a light shower after the hellebore is applied will remove all danger from it. Pyrethrum insect powder is a good, safe and effective remedy when applied just at night, but it is very expensive and difficult to obtain, of a good quality, at any price.

Where these insects nave made their appearance the first indication of them should be watched for in following years and great care taken to destroy the first brood each season. Growers 
of this fruit should be very particular not to neglect the bushes after the crop is gathered, for it is very important for the next year's crop that they should make a good growth of wood, and neglecting them at this time often allows a crop of worms to mature to cause more extensive injury the following year. The flies seem to prefer the folfage of native varieties of goose-berries, such as the Houghton seedling, for its eggs, and a few of
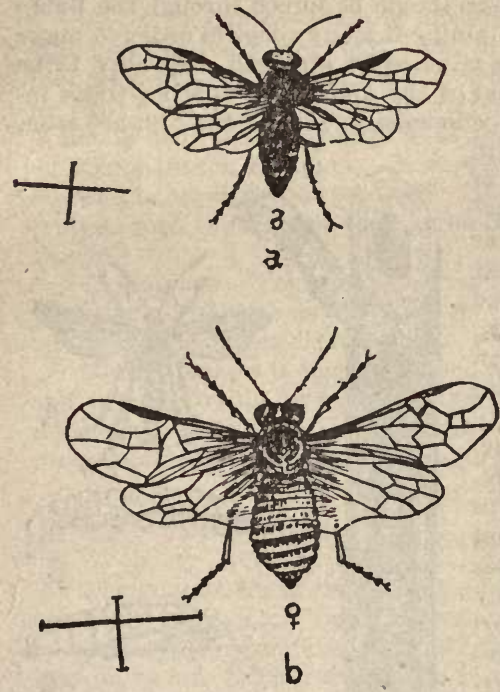
these bushes may be planted among the currants, when most of the worms can be very easily destroyed on them as soon as the eggs hatch.

Imported Currant Borer (Aegeria tipuliformis). Fig. 24. In many sections this insect in its larval state causes great injury to the stems of the currant and gooseberry by so weakening them that they break off when loaded with fruit, and by making them sickly. The female lays her eggs in the stems. early in the summer. In a few days the eggs hatch into little white grubs, which work into the pith of the stem where they make their burrows and

FIG. 23.-Mature form of the Currant Worm. 11 ve until the following $A$, male. $B$, female.

season. They then finish

their transformation and appear as wasp-like moths and the females shortly commence to lay eggs. This insect infests chiefly the red and white currant, but it also attacks the black currant and occasionally the gooseberry

Remedies.-The infested stems should be cut out in the autumn or very early in the spring and be burned at once. If the growers in any vicinity will follow th.s method in united effort they can keep this insect in subjection. Howerer, it is quite certain this pest will not continue for many years so very abundant as it is now, but that following the natural course of events it will be checked by parasites or some disease, and we may then enjoy a period of comparative immunity from it for a series of years.

Lice (Aphis ribis) are frequently very abundant on the follage of currants and gooseberries, where they cause the leaves to curl up and become distorted thus checking their growth, but seldom causing serious injury. They may be destroyed by spray- 
ing the foliage with tobacco water made by steeping the raw leaf or stems in hot water until it is the color of strong tea. Kerosene emulsion is also a very excellent remedy. It may be made as follows: Soft soap, one quart; hard soap (preferably whale-oil soap) one-fourth pound; two quarts hot water, and one pint kerosene. Stir thoroughly until all are permanently mixed, then add two quarts more of water. A force pump will be found the best thing to mix it with, and the mixture should be forced through the pump back into the receptacle containing it many times in order to make it permanent. In using this mixture its strength may have to be varied a little to suit the plant or the aphis. In fighting these insects it is very important to commence as soon as the first are seen, as they often increase with great rapidity. On account of the position of the leaves these lice are very difficult to get at with a spray, and on their first appearance the infested foliage should be destroyed. It is sometimes most practicable to dip the branches into the emulsion.

Diseases.-There are several fungi that attack the fol-iage of the currant. Perhaps the most common is the rust (Septosia Ribes), which causes the leaves to fall prematurely in July or August. The Bordeaux mixture mentioned under the head of the strawberry is probably the best pre. ventive, but should be used quite early in the spring and $\mathrm{F}$ ered. If used just before the fruit is ripe it will badly dis. figure it.

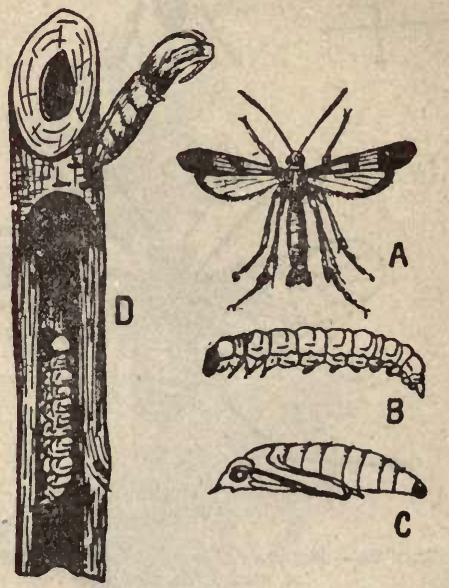

FIG. 24.-Currant Borer (Aegeria tipuliformis). $A$, winged moth; $B$, grown caterpiliar; $C$, pupa; $D$, stem split open to show caterpillar inside und an empty pupce skin above.

Varieties.-There are not so many varieties of the currant offered in the nursery catalogues as of most other cultivated fruits, but still there is much difference in the size and quality of the different kinds, as well as in the hardiness and vigor of the plants. For the home garden about one dozen plants well cared for will give an abundance of fruit. The following are the most important kinds :

RED DUTCH.-The variety most commonly cultivated and the most productive, hardiest and best kind known for general planting. Fruit bright red, small to medium in size and in good bunches. It will hang on the bush a long time after getting ripe without 
being seriously injured. The fruit seldom brings the highest price on account of its rather small size, but if severely pruned and highly manured it is greatly improved in this respect.

VICTORIA.-One of the latest varieties in time of ripening. Very satisfactory in every way and especially valuable for marketing. Fruit red, of large size in large bunches, and it hangs on the bush well after getting ripe.

FAY's Prourfic.-Plant of moderately spreading growth. Berries dark red, very large and borne in large bunches. It brings the highest price, but the plant is somewhat tender and liable to have its fruit buds injured in severe winters if exposed; on this account it should be protected, except in favorable locations.

LoNg Bunch Holland.-A very popular market currant. Berries red in color, in long bunches. Rather more liable to drop its fruit as soon as it is ripe than is the case with the Victoria or Red Dutch.

Cherry aNd Versailles.-Nearly identical large red-fruited varieties. They are not as hardy as the two kinds first mentioned, but do well in favorable locations.

WHITE GrAPE is the best of the white varieties and is sweeter and more desirable for table use than any before mentioned. It is prolific and very satisfactory in the home garden. But white currants seldom bring as good a price in the markets as the red kinds.

\section{GOOSEBERRY.}

The gooseberry is closely related to the currant, but is not so generally esteemcd. There are many species, but the varieties in cultivation are generally includea under two species, yet a third may enter into the parentage of a few of them.

(1) Ribes hirtellum. Native of the Northern States and Canada. Our best wild gooseberries belong here, and such well known kinds as Houghton Seedling, Downing and Smith are improved selections of it, little removed from the better representatives of the type in its wild state. Varieties belonging to this class are very hardy and generally most desirable.

(2) Ribes grossulacece. The European gooseberry in its wild state is not nearly so fine a fruit as the native American species, but by painstaking care many kinds having large berries and often of luscious quality have been developed, until in England it is regarded a fine table fruit. Varieties belonging to this species are poorly adapted to the dry climate of this section, and are prone to mildew and sunscald. Quite recently some very interesting hybrids between the two species have been brought out which produce very large fruit and yet appear adapted to our severe climatic conditions.

The directions given for growing the currant apply with equal force to the gooseberry, except in a few particulars which are included under the following heads: 
Propagation.-Most varieties do not grow as readily from cuttings as the currant, and kinds with coarse wood it is almost impossible to root in this way. For this reason layering is the most common method of propagation. If the layers are carefully put down in June after the new growth is several inches long each twig will be found slightly rooted by autumn. They should then be taken up, cut apart with a piece of the rooted main branch with each twig. These little layers should be set out at once in the spring and treated the same as recommended for currant cuttings. Some varieties need to have the bark slightly broken when they are laid down, but most kinds root readily without this trouble.

Planting.-Autumn is the time usually preferred for setting the gooseberry. The sprouts start into growth so very early in the spring that any delay at that time causes them a set-back from which they may not readily recover. But plants may be very successfully set in the spring if planted early.

Pruning should consist in taking out any superfluous or weak stems, as recommended for currants. Besides this, the size and appearance of the fruit of the common kinds will be greatly improved if from one-third to one-half of the new growth is cut off annually. However, some of the newer kinds producing the largest fruit may need this recommendation somewhat modified. Large fruit is picked and sold most readily and the quantity produced from a trimmed bush is, as a rule, fully as much as from one not trimmed. This is especially true of our native kinds which are inclined to overbear.

Mildew (Sphaerotheca Mors-tevae) is the worst disease of the gooseberry. It attacks the foliage which becomes covered with a whitish mould. Later the leaves dry up and drop off and the wood fails to mature." In bad cases the berries too are discolored, and perhaps ruined. As a rule this disease does not cause serious injury in good locations in this section, but in wet seasons, or any season on wet land, or where there is a poor circulation of air, it may be very destructive even here.

Remedies.-These should be preventive largely, and consist of allowing plenty of room between the plants for a good circulation of air and keeping them in as vigorous a state of health as possible by manuring and cultivating. If the disease makes its appearance in the face of these precautious recourse should be had to the following remedy, which is very satisfactory:

Spray the plants in the spring as soon as the young leaves begin to unfold, and repeat it as often as once in eighteen or twenty days, except in times of heavy rains when it must be done oftener. For this purpose use liver of sulphur (potassum sulphide) dissolved in water at the rate of one-half ounce to the gallon. The liver of sulphur dissolves very readily in hot water; costs from fifteen to twenty cents per pound, ard one gallon of the solution is enough 
for ten or twelve large bushes if applied with a spray pump, but if sprinkled on the foliage much more of the solution will be required.

Varieties.-The American kinds are best for general planting. Those most commonly offered by nurserymen are as follows:

HodghtoN SEEDLING is the hardiest and most satisfactory of the gooseberries for this section. It is prolific with little care in almost any situation. If neglected the fruit will be small, but it responds readily to good cultivation. Berries reddish brown in color when ripe.

DowNING has larger and sweeter fruit than the Houghton, but the bush is not so hardy. If laid down and covered with earth in winter it is a sure cropper, but otherwise it is liable to lose its fruit buds in this section. Berries nale-green when ripe.

SMITH's IMPROveD is a productive variety of good quality. Berries larger in size than the Houghton and yellowish green in color.

None of the European or their hybrids have proven a great success in this state. They generally mildew badly or sunscald, and require much care. The best of this class are the Industry and Triumph. The latter is a new kind of more than usual promise. 
CHAPTER IV.

\section{THE GRAPE.}

1.14ERE is probably no large section of Minnesota, or other 1 regions east and west on the same latitude, where some of the hardiest kinds of grapes cannot be grown and ripened, while on the latitude of the southern half of the state, and on the highlands near rivers and lakes many of the best varieties are easily grown in large quantities. Our popular cultivated grapes are almost without exception the result of the selection and hybridization of native species. In a few varieties we find a little of the European wine grape, but they are not generally as vigorous and free from diseases as the former. There are many native species in the United States, but those which enter largely into the parentage of the kinds most valuable at the north are:-

(1) Northern Fox Grape (Vitis labrusca), the species from which almost all of our popular varieties have sprung. Examples of these are Concord, Worden, Moore's Early and Lady. As usually found it has a large purple fruit, thick skin, and very pulpy meat surrounding the large seeds. The leaves are large, with whitish down on the underside. Found occasionally in the eastern part of Minnesota, and very abundantly in states farther east. The Concord grape resulted from the selection of seed from a wild vine which had been cultivated for two generations. Seedling labriusca are frequently white in color. The cultivated grapes of this class have perfect flowers with well developed stamens.

(2) Winter, or Frost Grape (Vitis riparia), the common wild grape found throughout Minnesota, except north of Lake Superior; as yet not much cultivated, but it is probable that some of its hybrids will prove valuable for severe locations in the Northwest.

(3) European Wine Grape (Vitis vinifera). In its pure state this has never been a success in open air culture in the Northern States, but the tine quality of its fruit has greatly improved the hybrids into which it has entered. The so-called Roger's hybrids, 


the Brighton, Delaware and others are the product of the union of $V$. vinifera with $V$. labrusca, and as a result we have among them varieties of the finest quality, though almost without exception they exhlbit some weakness in foliage or root, and a predisposition to disease not found in those of pure labrusca origin.

These species of the grape readily hybridize together. The blossoms of the cultivated kinds of grapes are generally perfect, as shown in Fig. 26. This is especially true of varieties of pure fox-

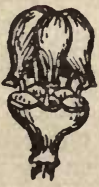

FIG. 25.

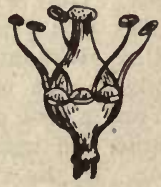

FIG. 26.

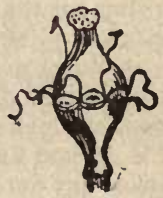

Fig. 27.

FIG. 25.-Shows the way in which the stamens push off the covering of the flower. The petals separating at the lower edge.

Fig. 26.-A perfect flower with erect (full developed) stamens.

FIG. 27.-A flower with reflex (weak) stamens.

grape ( $V$. labrusca) origin; while hybrids having some of the European wine grape ( $V$. vinifera) in their parentage often have flowers which are deficient in pollen. The latter have their stamens somewhat crooked and are said to be reflexed (Fig. 27). They frequently do not produce enough pollen to fertilize their own flowers, and when grown alone the bunches of fruit on them are perbaps only partially filled out, having many small, seedless berries. This feature is characteristic of the Lindley, Brighton and others, and varities with this weakness in their flowers should be grown near such kinds as the Concord, Worden, etc., which produce an abundance of pollen.

Propagation.- The grape is increased from cuttings and layers, and, to a very limited extent in this country, by grafting. Propagation from seed is resorted to only when new varleties are desired.

BY SEED. - If vines are to be grown in this way the seed should be saved from ripe berries. It should be at once sown in boxes of rich soil, or in a fine seed-bed, covering it a half inch deep and protecting by a mulch in winter. The plants will make a growth of one or two feet the first season, and will show blossoms about the fourth year. Some will have perfect and some staminate flowers, while others will have flowers with reflexed stamens; not one seedling in a thousand will be worth anything for fruit. The chances for obtaining good kinds will be much increased if careful, intelligent hybridization is resorted to.

By Cetrings.-Grape cuttings are of three kinds-long and short, hard wood and soft wood. The process by which they are 
rooted varies greatly in its details, but the general principles are the same in every case.

Long Hard-nood Cuttings.-These should be made in the fall from the hard, well-ripened new wood of the season. It is best to make them about eight inches long, if wood is aburdant. The length will necessarily depend somewhat on the distance between the buds on the canes, and when three-bud cuttings are made of some varieties they may be ten inches long. They are often made six inches long, but so short as this they are more liable to fail from drying out than if longer. They will send out roots best if cut just below a bud, but this is not necessary. These cuttings should be put up in bundles of about one hundred each. Bury them in some well drained place with the tops down, and cover with about six inches of soil and a foot or two of mulch. Be sure the soil is packed firmiy around and between the bundles, so that they cannot dry out in winter. In the spring, when the ground is dry, take all but about three inches of the soil from over the cuttings and replace it with about one foot of hot stable manure, to induce the cuttings to callous. This is very necessary, to insure their rooting, and they should not be planted out until well calloused. The same object may be secured by covering the cuttings with a box and sash, which will confine the sun's rays and so warm the roots that they will start a callous. When the soil is settled and warm they should be planted out, six inches apart, in rows two or three feet apart, putting the cuttings down to the top bud. They should be at least seven inches deep in most locations.

The LAND For CutTings.-The land selected for growing cuttings should be warm, light and rich. Its condition will be greatly improved if it is warmed by being plowed several times and having a coat of fine, warm manure turned in before planting. When planting on a large scale the land may be marked off with a line, and a sub-soil plow, run eight inches deep in the mark to loosen the soil, after which the cuttings ean easily be set by hand. The rows should next be straightened with a line, and each cutting carefully firmed by pressing close to each side of each cutting with the ball of the foot. When this work is well done the cuttings will be in the ground so solid that they cannot easily be pulled out with the fingers. The after-cultivation consists in continually working the top soil and keeping it loose and open. In the fall, if the plants are weak, they may be covered with earth and left where they are for another season's growth; but if strong, they may be dug and used for vineyard planting the following spring. It is customary to dig all the vines late in the fall, carefully sort them and heel them in out doors for winter, or else put them in a cold cellar. In the spring the strong vines may be used in the vineyard and the weaker ones be set out in the nursery to grow another year.

ONE-EYE CUtTings. - The wood for these should be cut in the fall and wintered over in a cold cellar, buried in moss, sand, saw. dust, or other similar material, or it may be buried out.doors. In 
the spring, generally in March, these canes should be cut up into pieces having one inch of wood be.ow and half an inch above the bud. Boxes about the size of an ordinary soap box, but only four inches deep, and having holes for drainage, should be prepared by putting in one and a half inches of rich soil and then about the same amount of clean sand on top of it. The cuttings should be set deep enough in the sand to just cover the bud, putting them two inches apart each way. The boxes may now be put in a gentle hot-bed, or on a bench in a greenhouse, and kept moist. The cuttings should be rooted in about six weeks. When they have made a good root growth they should be planted at a favorable time in rich soil out-doors. The time for this will be as late as the latter part of May in this section. Very nice plants may be grown in this way, but they do not make as strong a growth the first year as long cuttings, and often need a second year in the nursery before they are large enough for transplanting to the vineyard.

Sort-Woon Cutrings.-These are made from the green wood taken off while the plant is growing. They are rooted in sand in much the same way that florists root cuttings of geraniums, fuschias, etc. It is a method used only where wood is very valuable, and as a means to increase new varieties. Plants grown this way are apt to start slowly and to be wealk until well started, and should not be used when those grown from hard-wood can be obtained.

Layering.-This is the simplest, surest and easiest method of increasing the grape, and is the best way to grow them where but few vines are wanted. There are two kinds of layers, which are called spring and summer layers, from the season at which they are made.

SUMMER LAYERS are made in the summer, generally the last of July, from a branch of the same season's growth. They are likely to be weak for several years, and do not make as good plants as the spring layers. In making them the wood should be slit for an inch or so near the buds that are covered. Bury about one foot of the cane four inches deep in the ground and it will be rooted by late autumn, when it may be treated as recommended for weak yearling vines grown from hard-wood cuttings.

Spring Layers.-These may be made by laying down any cane early in the spring. It will root in one season. By fall it will have made a good growth of roots, when it may be cut from the main cane, and if s'rong it may. be divided into two plants. This form of layer is illustrated in figures 28 and 29. By a little different treatment of the spring layer a vine may be grown from each bud on the layered cane. For this purpose some thrifty cane should be selected in autumn, pruned of its laterals and burled. In the spring it should be uncovered and only one shoot permitted to grow from each joint. After the new growth has started about six inches from each bud the whnle cane should be layered about four inches deep, handling it carefully so as not to break the new 
growth. Figure 30 shows such a layer after it has rooted. It is a good plan to cover it not more than three inches at first and to fill up the trench as the shoots grow. If covered four inches deep at once the young growth will sometimes rot, though this seldom happens, and some skillful growers fill the trench full at once. In the autumn roots will be found growing from each joint, and these may be cut apart and treated as recommended for weak vines grown from cuttings. If this method of propagation is to be used to some considerable extent vines should be grown specially for the purpose. It is not a good plan to use fruiting vines for layering to any great extent, though it may be safely done in a small way. The subject of grafting the grape will be considered later in a special chapter on grafting and budding.

Location of the Vineyard.-Some of the hardy, early ripening but inferior grapes will mature in almost any situation, but

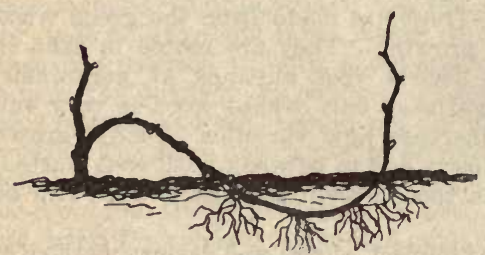

Fig. 28.-A Rooted Layer. the better $k ı$ inds need a warm exposure and free circulation of the air about them to insure their ripening each year. High southern slopes generally offer the best locations; in such places there is the greatest amount of heat in summer, very general immunity from the late frosts of spring or the early frosts of autumn, and a movement of the air at all times; all of which are important matters in growing grapes. Other slopes, and even level land, may be successfully used for this purpose, but on northern exposure the fruit will be later in ripening than if in situations where the plants receive the direct rays of the sun. However, excellent fruit may often be grown on a northern slope if it is near some large body of water, which will help maintain an equable temperature, and especially to keep off the early frosts of
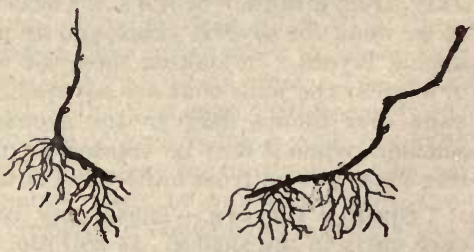

FIG. 29.-The rooted layer separated, mak ing two plants

autumn. In a vineyard closely shut in so that the foliage of the vines does not dry off quickly after summer showers it will be found very difficult to grow many of our better kinds of grapes, on account of the prevalence of fungus diseases in such places. The cutting away of a belt of trees surrounding a vineyard, so as to allow a free movement of air through the vines at all times, has often been the means of making the difference between failure and success in growing grapes. 
Soil. - The best soil for a vineyard is a rich gravelly or sandy loam, with an open clay sub-soil ; but a somewhat clayey loam will do very well if sufficiently drained to remove any excess of moisture. Before planting the land should be thoroughly prepared by plowing and harrowing until in the best condition. Where there is not good surface drainage, as on some prairie farms, it will be found a good plan to plant the vines on ridges made by turning six furrows back to back. In other locations the land should be kept smooth.

The Best Vines for planting are strong one-year or thrifty two-year-old plants from layers or cuttings, and only those having a good root system should be used. Plants more than three years old are not desirable, as young, thrifty plants soon outgrow those that are old and large when transplanted. It matters little about the direction of the rows, they should be laid out so as to prevent the wash as much as possible.

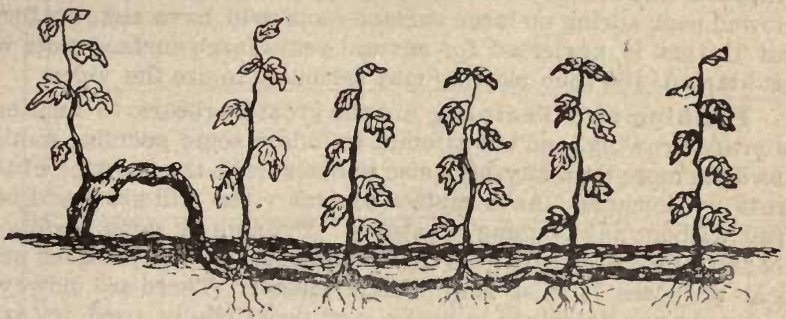

FIG. 30.-A rooted layer. Each bud making a new plant.

The Distance Between the Plants will depend somewhat on the kinds planted, the manner of pruning and the soil; but the strong growing varietles, which are most desirable, should generally be set ten by ten feet apart each way, to allow for the growth of roots and a good circulation of air between the vines. When the vineyard is much shut in it will be found advantageous to increase this distance, but when located in an airy position and on retentive soil the plants may be set eight by eight feet.

Planting.-The most rapid way of planting is to furrow out the land both ways and put the vines at the intersection of the furrows. Before planting the tops of the vines should be cut off so as to leave only two or three buds, and if the roots are very long it will facilitate planting to cut them back to eight or ten inches in length; shortening the roots to this extent does not seem to injure the growth of the plant. On light soil it is exceedingly important to get the roots down deep in the land, and the holes should be made large enough to allow the lower roots to come about fifteen inches below the surface. The top loam should be put around the roots, but the plants should not be covered at once more than two inches deeper than they grew in the nursery. The soil should be 
gradually worked in around the vines as they grow until the holes are full. On heavy soils, especially those quite moist, it is not safe to plant deep, and eight inches will probably be found about the right depth in most locations. In planting vines to be pruned on the one-cane system, which is generally practiced by grape growers in this region, it is best to incline them somewhat in the direction in which they are to be trained on the trellises, this should be in the direction of the prevailing summer winds.

Cultivation.-Soon after planting the vines should be well cultivated, and some hoed crop that will not shade them may be grown between the rows for the first two years. After this the vines will need all the land. Cultivation should consist of a shallow plowing early each spring and during the summer. The top soil should be kept loose and light by shallow cultivation. Deep cultivation or much cultivation late in summer is not desirable in a vineyard, and it may cause serious injury. If the land is lightly plowed each spring no large surface-roots will have time to form; but if this is neglected for several years large surface-roots will get started, and then plowing may seriously injure the vines.

Pruning and Training are the great bugbears to amateurs in grape growing, and the attempt to follow some peculiar method has done more than anything else to discourage the growing of this fruit by farmers. As a matter of fact vines will grow and bear fruit without any pruning whatever. Pruning is done simply to get the most good fruit from the least amount of vine, and for practical purposes it is a very simple matter. There are, however, many systerns described in books, and occasionally used in practice, that are quite complicated and difflult for a beginner to understand. The practical points to have in mind in pruning grapes are: (1) That the old wood which has borne fruit once never bears again. (2) That the wood that is formed one season produces the bearing wood for the next season. (3) If all the new wood is left on the vine it will bear ten times more clusters than it can properly develop, and they will all be small and imperfect. (4) If ninetenths of the new wood is cut away leaving only from three to six buds to each stalk the yield of good grapes will be much increased. (5) It is desirable in severe climates to train the vine so that it can be laid down on ihe ground with but little resistance, for in such locations it is necessary to protect it each winter.

If these points are borne in mind it matters not so very much what system or whether any system at all is pursued in pruning. However, it will be found most convenient to adhere somewhat cleariy to some simple system 
of pruning. But whatever plan for after-training is adopted the care of the vine for the first two years shouid be about the same.

The First Year no support or pruning is needed. The vines will ripen their wood as well on the surface of the ground as if tied to stakes, but it will be more convenient about cultivating if they are staked. Late in the autumn of this year all of the vines should be cut away except three or four buds, as shown in Fig. 31, which should be covered with a mound of earth four or five inches deep, and later on, before cold weather sets in, apply a covering of mulch, two or three inches in depth, of straw or litter of some sort. This mulching is absolutely necessary to insure the wintering of newly transplanted vines.

Trellis.-The following spring a trellis should be built-uniess stakes were set the first year, when they may be used again-and

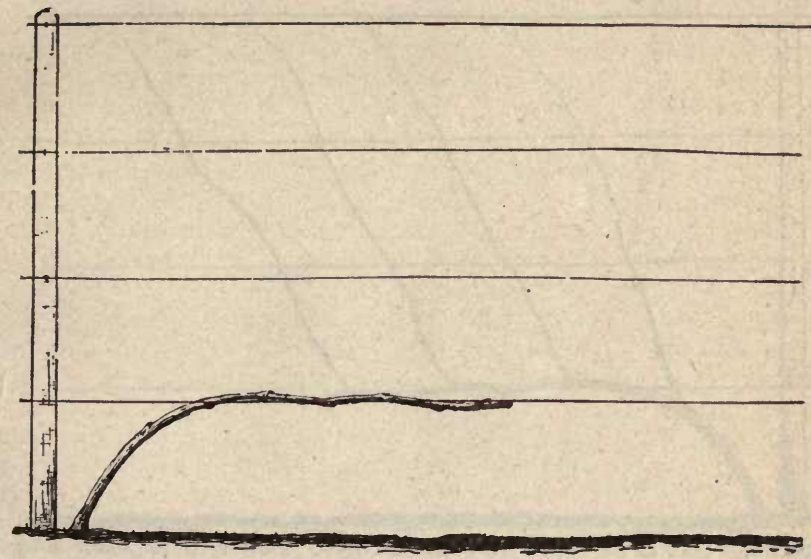

FIG. 32.-Vine in spring of the third season.

the work of putting up a trellis be deferred until the opening of the third year. The form of trellis may vary greatly, but a very practical and simple kind is made by setting posts twelve feet apart in the row, and using four wires of No. 12 galvanized iron, putting the lowest one about eighteen inches from the ground, and those above ten inches apart. The wires should be fastened securely to one end post, passing through the other end and through staples driven in the inside posts, so as to allow the wires free play through them. This method allows the loosening of the wires in autumn and tightening them in summer.

The Second Yrar, as soon as the weather is settled, the vine should be uncovered; the garden fork being the best tool for this purpose. Permit only one bud to grow, and that the strongest that. starts. Rub off all the others that show, while they are small. 
Tie the cane as it grows to the 'stakes or wires, and if it grows rapidly pinch off the top once when it reaches the upper wire. In carrying out some systems two canes are permitted to grow this year, but the system best adapted to commercial vineyards is practically as follows: The pruning in the fall of the second year should consist in cutting off all the laterals-in other words in cutting off all the side branches close to the main cane. In pruning the main cane leave about two-thirds of the growth it has made, but not more than four feet long. The vine should then be buried as directed for the previous year, and it will be found convenient to bend it as low as possible. To do this to the best advantage take away a little soil from near the vine, to permit part of the bend to come near the ground. As the vines get older and stiffer they will be found to bend most easily and safely below ground.

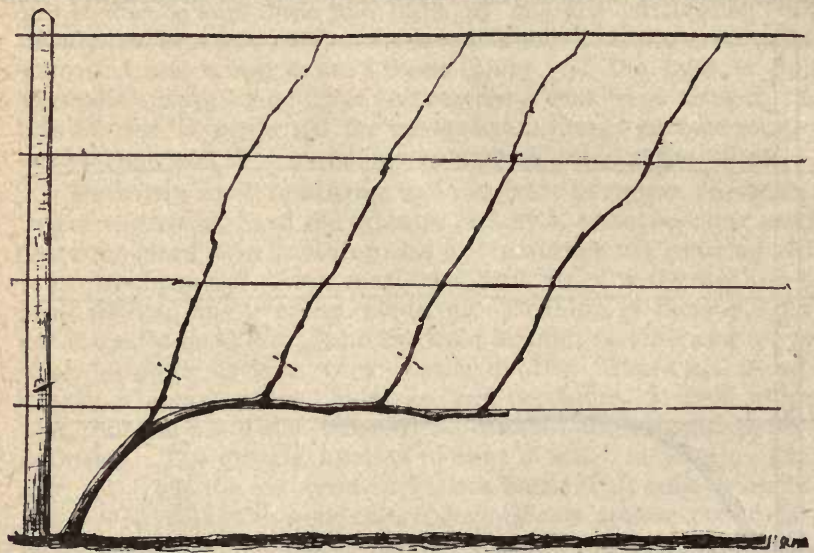

FIG. 33.--Vine in autumn of the third season. Dotled lives show where pruning should be done.

Third Season.-The third spring the cane should be tied along the lower wire (see Fig. 32). If it has wintered well two shoots will start at nearly every joint. As soon as these are three or four inches long the weakest should be broken off and only the strongest ones, that come about ten inches apart, be allowed to grow. In selecting these shoots preference should always be given to those coming out on the upper side of the main cane. As these shoots push upwards from the main cane they should be tied to the wires (see Fig. 33), and when they have reached the top of the trellis each of them should be pinched off at the end. This pruning will check the growth a little and result in the fruit buds being formed nearer the main cane than they would if not checked. Further pinching is sometimes practiced when the finest bunches of fruit are wanted, but for practical purposes one pinching is enough, and 

some large, successful growers do not pinch at all, though it is probably a mistake not to pinch once, if this system of pruning is followed.

If the vine is thrifty it will bear several pounds of fruit this year. As soon as convenient after gathering the ripe fruit the vines may be pruned. It is not necessary to wait for a frost to kill the leaves, and it will not do any harm to bury with some of the leaves on the vine. In this region the time of pruning is between the middle of October and tenth of November. Where one has but few vines it is best to wait until there is danger of the ground freezing hard before laying them down, but in large vineyards it is not practicable to wait so late, and the work must commence earlier. In pruning the third fall, first select a cane near the extremity of the main cane and cut it off at a length sufficient to reach the

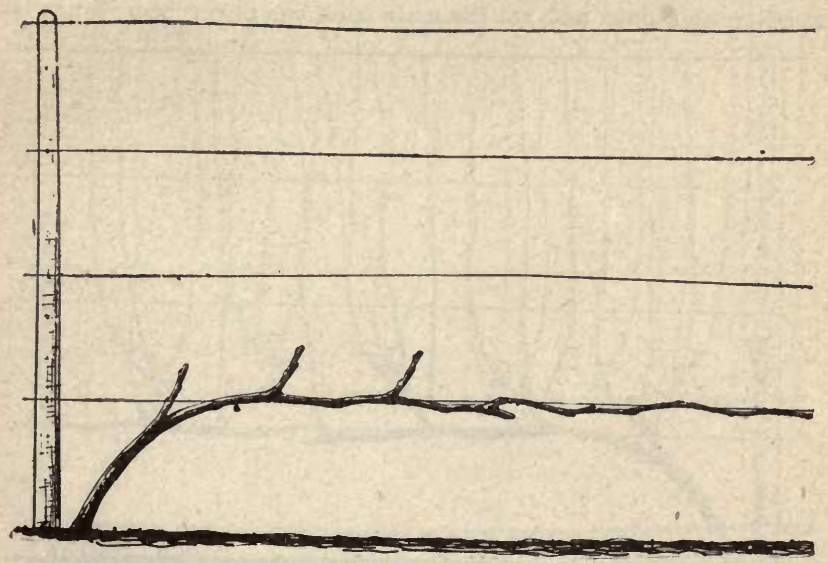

FIG. 34.-Vine in spring of the fourth season.

next vine on the trellis. This cane must be tied to the lower wire the following (or fourth) spring, and will complete the permanent main cane (see Fig. 34). The rest of the pruning this fall will consist of cutting back to from three to six buds the other shoots that have grown from the main cane. Any small side branches that may remain should be cut off, and the vine when ready to lay down should resemble Fig. 35, which shows it properly tied to the trellis the following spring. In pruning do not cut nearer than within one inch of any bud, to avoid winter killing. Bury as directed.

Spur is a term used to indicate the short stubs of the laterals that remain on the main cane in this and following years after pruning. From these spurs come the new growth and fruit each season. It is desirable to keep them as short as possible, but with some varieties it will be found difficult to keep them very 'short; 
for instance, Moore's Early is a shy bearer, and if pruned very close will not bear even a fair crop, consequently the spurs on it must be left longer than on some other kinds that are more prolific. But careful attention in pruning to save the growth from the low. est bud on the spur will aid very much in keeping them within bounds. (See Fig. 31.)

These spurs should be about ten inches apart on the main cane. If in after years some of them are lost, or they become too long, a new main cane may be introduced by encouraging the growth of a new shoot or by renewing the main cane with a shoot from a spur near the ground, after which, when well started, the main cane may be cut away. However, there are vineyards in the hands of careful cultivators that have grown large crops for many years, on which none of the spurs are lost, neither are they long enough to be at all troublesome, and yet the main cane has never been renewed.

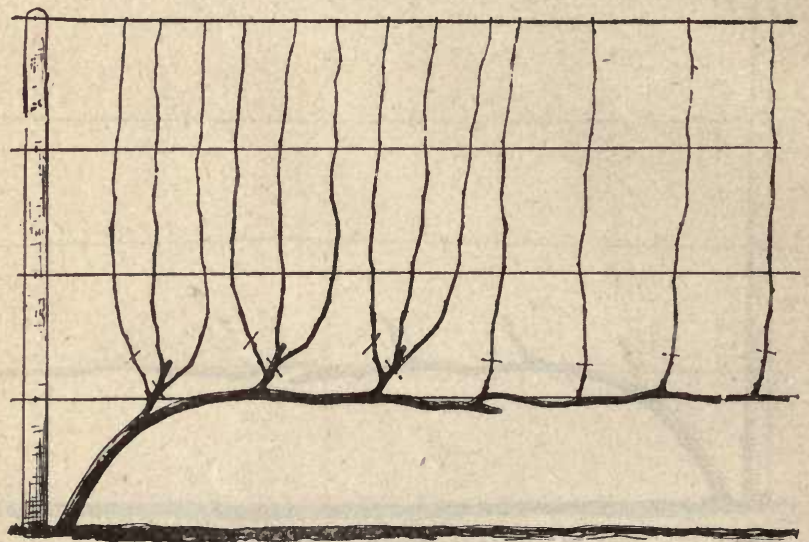

FIG. 35.- Vine in autumn of the fourth season. Dotted lines show where pruning should be done.

Fourth Season.-Tie the vine to the lower wire in the spring as directed, when it should appear much as in Fig. 34. Permit only one shoot to grow from each bud on the spurs. These should be pinched once when they have reached the top wire, and after that allowed to grow freely. This autumn, and subsequently, when pruned the vine will consist of a main cane extending along the lower wire of the trellis to the next vine. It will have spurs on it of three or more buds each, standing some eight or ten inches apart, as shown in Fig. 36. Under this system if the canes are not pinched in summer the fruit buds will be formed high up on the laterals and consequently the spurs will have to be left very long in order to have any fruit, while if pinched, the fruit buds will be formed nearer the main cane, and the spurs can be kept short. It 
has frequently happened that inexperienced persons failed to get much fruit on their vines because in pruning they had cut away all the fruit bearing wood. However, this pinching should never take off more than the tip of the cane.

Removing Foliage.-Under no circumstances should any considerable foliage be taken from the vine while it is growing. The notion that ripening fruit needs the sunlight is very much at fault. Grapes ripen best where the fruit is in the shade and the leaves in the bright sunlight. The leaves are, so to speak, both lungs and stomach to the plant, and anything that injures them prevents the ripening of the fruit.

An Easy System of Pruning, and also one that is well adapted to practical purposes, may be described as follows: Plant

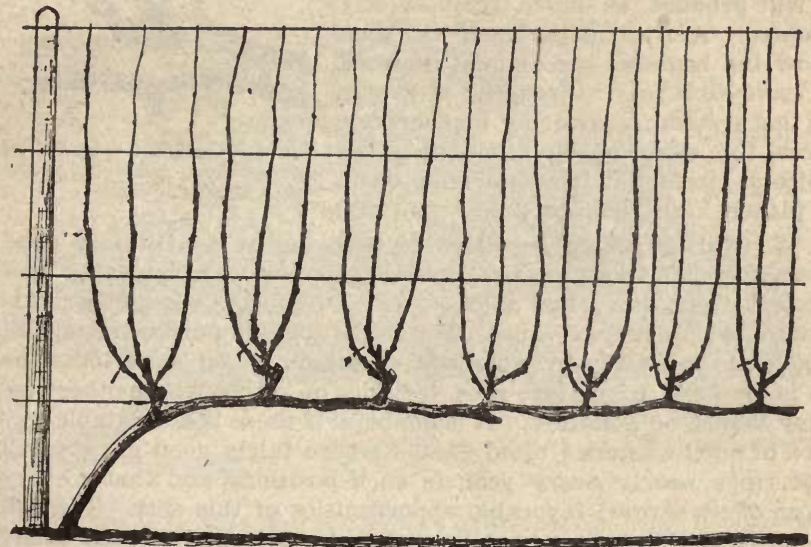

FIG. 36.-Permanent vine in autumn of fifth and subsequeni years. Dotted lines show where pruning should be dune.

the vines twelve feet apart in the rows. The second year permit two shoots to grow, and in pruning in the autumn of this year cut out the weak wood only. The third year tie one cane to the lower wire and the other to the third wire. Encourage the vine to spread over the trellis, and in pruning leave perhaps one-third of the new wood. In after years retain encugh young thrifty wood to fully cover the trellis, which will be a:l that the roots can properly support, and cut out as much old and weak wood as practicable, and shorten any very long canes. This will require the cutting out of perhaps four-fifths the new wood each year. As the vine gets old encourage the growth of one or two young shoots from near the root. When the main cane becomes so stiff that it cannot be easily buried in winter it may be replaced with one of these shoots from near the root, or what is generally preferred, the stiff part of the main cane may be buried permanently and some of the younger 
wood, branches from the main cane, may be trained to form a new main cane. The main cane so laid down will become rooted and thus strengthen the new vine formed from one of its branches. Under this system no summer pinching is necessary. After the vines have been trained in this way for eight, ten, or more years, there should be many flexible main canes, and as they get old and too stiff to bend easily they should either be cut out and replaced by some young bearing shoot or layered as recommended. Trained in this way a vineyard does not look as symmetrical and pretty as when grown on some more regular plan, but it will produce as much fruit as any system. A little experience will soon show the beginner the amount of wood to leave each year. Vines may be grown on this system for covering high arbors, trees, the sides of buildings or otber objects. In fact it is better adapted to a rather high than to a low support.

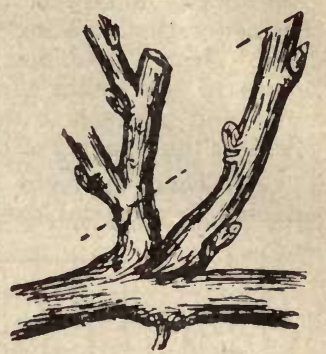

FIG. 37.-A Spur. The dotted lines show where the pruning should be done.

Training vines against buildings or walls is a good plan, and such treatment will hasten the period of ripening and protect from early and late frosts. Of course, the southern exposure is always preferable. The trellis for this purpose should be about one foot away from the wall or building. In such locations it is possible to mature good varieties of grapes where otherwise they would be a failure. It is doubtful if there is a habitable section of northwestern United States where fairly good grapes will not ripen nearly every year in such positions, and almost every farm offers several favorable opportunities of this sort. The soil close to buildings may not be such as is desired, but it can easily be improved, or entirely removed and a better kind substituted. And sometimes what would be a very poor soil for many other crops is just what is needed for the grape. There are cases where in such locations single vines have borne several hundred pounds of grapes in one season.

Pruning Neglected Vines.-When vines have been neglected for several years it is often a difficult matter for the beginner to bring them under any system of pruning, and they are on this account allowed to go unpruned and unproductive. Sometimes such vines may best be brought into shape by cutting away nine-tenths of the wood and then carefully thinning out and pinching the young growth that may start. At other times again it may be best to cut the whole vine off at the surface of the ground. If this is done at the proper season for pruning several sprouts will start from near the root, but only one, or at most two, should be sared. These sprouts should be trained the same as a newly planted vine, except that in one season they will make a vine large 
enough to bear a good crop of fruit the following year. By either method only one fruiting season is lost, but as a rule the greatest success attends the latter method.

Time of Pruning. - The best time to prune the grape is late in the fall or very early in the spring. If the vines are to be laid on the ground in winter of course they should be pruned in autumn, as doing it then will greatly facilitate the laying down process. If for any reason the vines have not been pruned until the buds have started, it is far better to do it then than not at all. The so-called "bleeding" of vines does not appear to seriously injure them, though pruning when the sap will run from the cut surfaces is a bad plan.

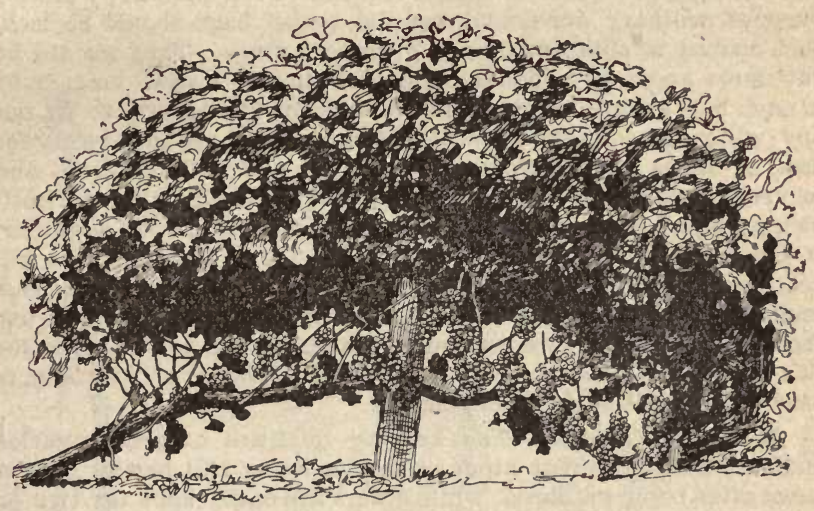

FIG. 371/2.-An old grape vine pruned on the one-cane, spur renewal system as recommended. From a photograph.

Thinning the Fruit.-Under almost any system of pruning some varieties will set more fruit than they can properly mature. Where this is the case the poorest bunches should be cut away as soon as the berries are well formed. As a rule, the improved appearance of the remaining fruit is so great, as the result of this thinning process, as to make the operation a paying one.

Manures.-Ordinarily the new soils of the northwestern states contain an abundance of plant food. Grapes do not require much manure, and the best kinds for them are those which have but a small amount of organic matter, such as wood ashes. Yet on gravelly or sandy lands they may be much benefited by the liberal use of stable manure. Never apply manure so long as the vines are making a satisfactory growth without it. A very rapid, long growth is not nearly as desirable as that which is well matured and moderate in quantity. 
Bagging Grapes.-In sections of the country where black rot of the fruit is abundant it may be profitable to put all the grapes in bags, but in sections where this disease is only occasionally destructive it will seldom be a paying operation. But in grow. ing fruit for home use, or where something very nice is wanted, it will often be worth undertaking, as the expense for labor and material need not exceed a half cent per pound. The bagged grapes have a little thinner skin than those not bagged, are free from dust and spiders' webs, and are not so liable to be caught by the first autumn frost. Some varieties seem to ripen more evenly when bagged.

Bagging should be done when the berries are about the size of small peas, and if there is danger from rot, even earlier. For this purpose ordinary one-pound manilla paper bags should be used, such as may be obtained from any grocery store. They should be cut down about two inches on each side, and a small hole made in each bag, generally by cutting off the lower corners, to let out any water that might collect in them. They are then ready for use. A bag is brought up over the bunch, above the branch, and securely fastened with a pin. The bags should be left on until picking time, when the bag and bunch may be taken off together. If the fruit is to be stored it will be found that the fruit wiil keep longer in the bags than without them. Generally the bags remain on the whole season without trouble, and some growers use the same bags for two seasons. Cloth bags made especially for this purpose will last about four years. In France a wire bag is used to some extent for this purpose.

Keeping Grapes.-The keeping qualities of grapes varies much with the different kinds; some varieties will hardly keep a week after being gathered, while others are easily kept for two or three months by using only ordinary care. A moist, cold cellar is a very good place to keep them. The bunches should first be relieved of any cracked or injured berries, and then laid one tier deep on shallow trays or shelves, so that the air may circulate freely among them. The fruit should be perfectly dry when put in the cellar. If the cellar is not cool when needed for use some ice may be put in it in a tub and the windows kept shut in the day time and opened at night. If the grapes are packed in dry saw dust or cork bark they will keep even better than on trays. Where cold storage is accessible they may be packed in baskets before being stored, but in any case great care should be taken to remove any injured berries, or they will rot and spoil those near them.

Girdling the Grape to advance the period of ripening is practiced to a limited extent, but there is quite a difference of opinion regarding the ultimate effect of the operation on the health and vigor of the vine. It seems, however, to be pretty generally conceded that it can be done to a limited extent without serious, if any injury. That it generally advances the period of ripening from seven to ten days, and that the fruit from girdled vines is 
considerably larger than from vines not girdıed and of just as good quality. But on the other hand, some very careful experiments made by Dr. Jabez Fisher, of Fitchburg, Mass., seem, in his words, to show that "whenever a grape will ripen fairly well by natural processes girdling is a complete draft unon the future without prospect of means to pay it through the gains of the present" The operation consists in taking out a ring of bark one-fourth inch or more in width, at any time during the growing season, but generally soon after the berries are well set. For this purpose a special. tool is often used, which makes two cuts and takes out the bark with one movement (Fig. 38). If the whole vine is girdled at the

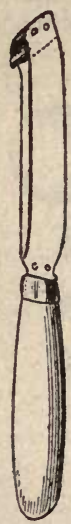

FIG. 38.

Girdling knife, made of two thin steel blades with cleaner at $a$.

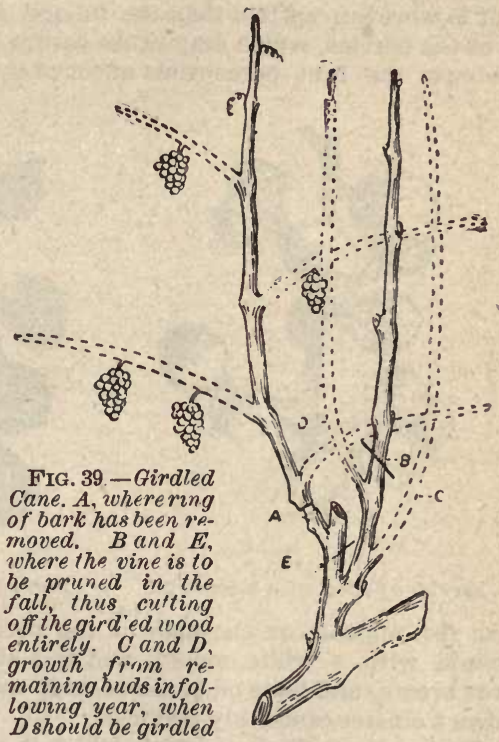

surface of the ground it will soon show great weakness, so when practiced at all it should be done by girdling the lateral canes; those that are to be cut away entirely when the vine is pruned (Fig. 39). In sections where early autumn frosts are common it is frequently desirable to try this method of advancing the period of ripening.

Diseases.-There are many diseases which may at times attack the grape, but only two are commoniy met with in the northwestern states, where on account of the dryness of the air there is less trouble from fungus diseases than where the climate is more humid. 
Downy MILdew (Poronospora viticola). This fungus may attack the young wood, flowers or fruit, or all these at the same time. When it attacks the follage it first appears as greenish-yellow or brownish irregular spots on the upper surface, with corresponding spots of whitish frost-like mildew on the under side. The effect of this is to cause the leaves to dry up and fall off, frequently when the fruit is quite green, which consequently does not ripen. But besides the loss of the fruit from this disease the wood is often left in a very immature state, and the whole plant so seriously weakened that it will not produce a full crop of fruit for several years. It frequently acts in this manner on the Delaware, while it seldom injures the fruit of that varlety. On other varieties the fruit is more susceptible than the foliage, and it produces brown rot of the berries, which may cause severe losses some seasons. In this case the first perceptible effect of the disease is when a pur-

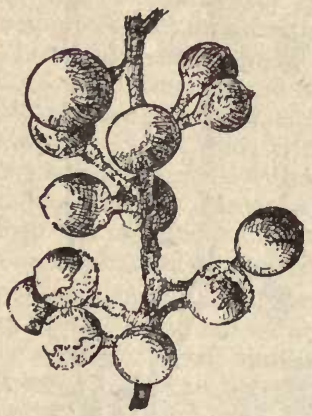

FIG. 40.

Berries affected with brown rot.

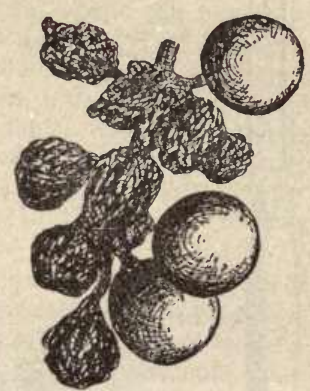

Fig. 41.

Berries affected with biack rot.

plish spot appears on the side of the berry. Later, the fruit is covered with a white mould, and in a short time the whole fruit turns brown, and later on becomes soft and wrinkled. Figure 40 shows a cluster of mouldy berries.

BLACK ROT affects the fruit which it seldom attacks until the berries are two-thirds grown; these shortly dry up, turn black, and remain hard and dry on the vines, often until the following spring. Each dried berry is covered with minute postules. This disease is only occasionally injurious in the northwestern states.

Preventives.-There are no remedies for either of these diseases, for after the fungus finds a lodgment in the tissues of the plant we are powerless to destroy it without injuring the plant itself. Consequently every effort should be used to keep the fungus from getting a hold on the plant. It has been found that where the vines are closely shut in, so that there is but little circulation of air and the water does not quickly dry off the foliage, or where 


the soil is wet and cold, that the vines are very liable to become diseased. On this account where a vineyard is subject to these troubles the first thing to do is to remedy, so far as is practicable, anything that obstructs free circulation of air through it. If the land is moist and cold it should be underdrained. For brown and black rot of the fruit early bagging of the clusters will be found quite effective. But after these things are done disease may gain a foothold and cause serious injury to weak varieties in warm, wet seasons. Some varieties are almost uniformly healthy in good locations, while others are very susceptible to disease. Yet these latter are often the most profitable kinds to grow for marketing purposes. To grow these successfully recourse must be had to treatment with fungicides, and the following is probably the best method of proced are, and if carefully followed the expense of the operation and the loss from disease will be very slight.

Use of Fungicides.-As soon as the fruit has set spray the vines thoroughly with Bordeaux mixture, made as recommended. in chapter on strawberries. Repeat the spraying once in two weeks until the grapes begin to color, using Bordeaux mixture until August 1st, and after that date the ammoniacal solution of carbonate of copper, made as recommended below. Bordeaux mixture should never be used after August 1st, or it may adhere to the grapes when they are ripe and make them unsalable. The carbonate of copper mixture has sometimes been successfully used alone without the Bordeaux mixture, but the latter is most desirable because it stays on the vine even in very rainy weather, when the former would be washed off.

For applying these mixtures a knapsack sprayer and a nozzle that makes a fine spray should be used. There are now many good patterns of these offered by different companies at reasonable prices. Of course a common syringe with a rose nozzle could be used for this purpose, but it will be found to waste a great deal of the material on the ground and put more on the plant than there is any need of. Carefully conducted experiments show that when these insecticides are applied as directed there need be no fear that injury will result from the small amount of copper that is put on the fruit. Almost without exception the copper is all washed off the fruit before it is ripe. In extreme cases where Bordeaux mixture remains on the fruit it can all be taken off without even injuring the bloom by dipping the fruit into water slightly acidulated with vinegar. The fruit does not absorb any of the copper.

Ammoniacal Carbonate of Copper is made by dissolving one and one-half ounces of precipitated carbonate of copper in one quart of commercial ammonia. Then add this solution to twentytive gallons of water. The ammonia should be kept tightly corked. in a glass or earthen vessel. The solution should be added to the water immediately before spraying, otherwise some of the ammonia may be lost by evaporation. 
Insects.-The grape is generally quite free from insects in this section, but the two following named species are occasionally troublesome, besides which there are several others that may cause damage in the future, but as at present they are not numerous erough to do much harm they are not referred to here.

Grape Vine Flea Beetle (Graptodera chalybea) is the name of a small, dark colored beetle that is most injurious from its habit of gnawing out the buds from the canes in early spring before vegetation has started. Later in the season it feeds upon the leaves on which the female lays her small orange-colored eggs in the last of May or first of June. The young larvæ riddle the leaf with holes, or if very numerous eat all except the largest ribs, but they or the beetles seldom cause serious trouble after the vine is in leaf.

REMEDY.-The beetle may be jarred from the vines by a sudden shake, therefore by putting a piece of cotton cloth, saturated with kerosene, on the ground under and on each side of the vine before it is jarred the beetles are destroyed. They have only to touch the kerosene-corered cloth and they are almost instantly killed. Care should be taken that the pieces of cloth are together around the base of the vine. A warm, bright afternoon is the proper time to do this work, and it should be very faithfully performed every day until the vines are out of danger. By two persons working together, one on each side of a row of vines, each with a piece of cloth, the work can be done very rapidly.

The Eight Spotted Forester (Alypia octomaculata) is the name given to a blueish looking caterpillar that sometimes is quite destructive to grape vines and the Virginia creeper by eating the foliage. It may be kept in check by hand picking where there is only a limited number, but when very abundant recourse must be had to the poisoning of the foliage with arsenites.

Varieties.-For home use the hardy, healthy, productive kinds that do not require much special culture, should always be given the preference; while for marketing varieties those that need special culture may sometimes be most profitable. The following list includes the best of the varieties that have been well tested, yet there are many others that produce well, and in favored locations may even be superior to some of those mentioned. For the ordinary family a dozen vines are a great plenty, and three or four that are well managed may give far more fruit than a dozen that are neglected.

Brighton.-A superb red grape of finest quality, of strong growth and productive. It gives quite general satisfaction, but in poor locations frequently fails to ripen evenly. Its flowers have reflexed stamens and it should be planted. near perfect flowering kinds.

CoNCORD. - Where it will ripen it is the most productive and satisfactory grape grown. Of good quality, vigorous, hardy and healthy. In unfavorable locations in this section it often fails to ripen. Black grape. 
COTTAGE. - A vigorous, healthy, hardy, productive black grape of very good quality. Very early, and on account of this and its quality it should be generally planted in the home garden. It is rather undesirable for marketing on account of the berries easily separating from the stem soon after being ripe.

DELAWARE. - A small, red grape of extra good quality. Generally more popular than other kinds with commercial growers, but it is quite liable to mildew in some seasons, and on tris account should be avoided except by those who have extra good locations, or who will give it extra good care.

HARTFORD. - A well known early black variety of fair quality. Very productive and hardy.

JANESVILLE.-Very vigorous, healthy, hardy and productive berry, black, rather acid, of medium size in a very compact cluster. It colors very early. This is the most desirable kinds for very severe locations.

LINDLEY.-Like the Brighton, deficient in pollen, but quite productive when grown near other kinds. Of extra quality and one of the best keeping kinds; with ordinary care it will keep until January

LADY. - An early white grape of excellent quality; hardy and healthy. Not very productive.

Moore's EARLY. - The earliest grape of extra good quality. Vine hardy, vigorous, healthy, but not very productive. Berries very large and black with a heavy bloom. It requires rich soil and high cultivation for best results.

Pocklington.-A little later in ripening than Concord, and is among white grapes what that variety is among black kinds, the most productive and satisfactory where it can be ripened. Hardy, healthy and productive. Only adapted to best locations.

WORDEN.-A magnificent black grape of better quality and ten days earlier than Concord. Hardy, productive and healthy. For general planting to be preferred to Concord. It should be in every collection. Occasionally it drops badly from the stem. It brings the highest price where well known.

Green Mountain is a new grape that is promising for home use on account of its being very early and of extra quality. Berries small and greenish-white in color. They seem inclined, however, to drop easily from the bunch.

MOORE's DIAMOND.-A very promising new white grape of good quailty, ripening from four to eight days before the Concord. Very hardy and productive.

List of Varieties Recommended.-For very severe locations: Janesville, Ives, Hartford.

F'or fairly good locations: Janesville, Hartford, Cottage, Worden, Lady, Brighton, Moore's Early.

For extra good locations: Concord, Delaware, Worden, Lady, Cottage, Pocklington, Lindley, Moore's Early. 
CHAPTER V.

\section{THE CRANBERRY.}

(1) RANBERRY (Vaccinium macrocaepon). This is the low trailing cranberry of the swamps of many of the northern states. The form and habit is well illustrated in figure 42. The so called high bush cranberry is a shrub and is much more widely distributed than this. The latter has one flat seed in each fruit, while the former is a many seeded berry. This plant is not adapted to general cultivation, and seldom if ever does well on the prairies of the West. It may be laid down as a general rule that it cannot be successfully cultivated except on the granitic soils of the northern states, and that it will be a failure on the limestone drift soils, such as are common to the prairies of Minnesota, Iowa and the Dakotas. In Wisconsin and eastern and northern Minnesota it is often very productive, either wild or cultivated, and is an article of much importance in the markets of ibose sections each year. Where this fruit

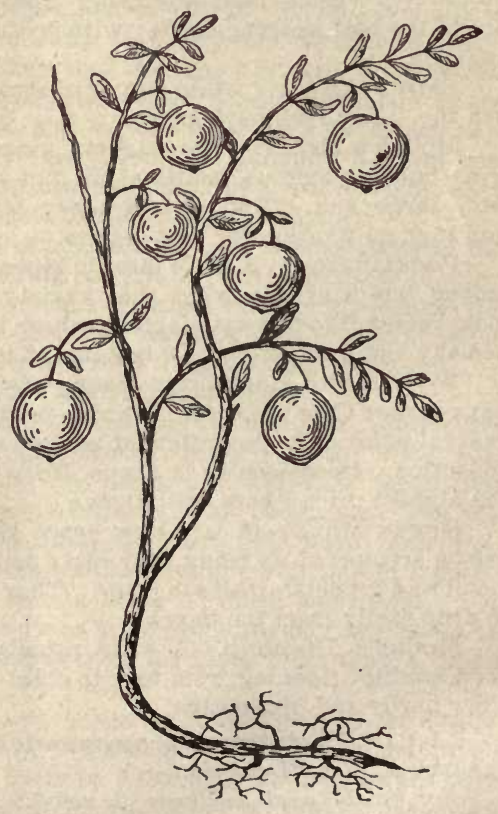

FIG. 42-Cranberry plant and fruit. 
can be cultivated it is often the most paying crop that can be grown.

Best Location for Cranberry Beds. - In a wild state this plant is found at its best on moist land where the water level is within eighteen inches of the surface. It seems to be rather indifferent about the soil, sometimes growing on sand and then on peat mud or moss. As a rule the best locations are low meadow lands sloping down to ponds, or watered by brooks or creeks, somewhat sheltered but shaded. On uplands it has been successfully cultivated, but in such situations it is generally unprofitable and frequently an entire failure. It may be laid down as a rule that the soil in which this plant is to thrive must be liberally supplied with water, and yet the land must be so drained that the water can at will be drawn off to at least ten inches below the surface. The best cranberry bogs are so arranged that both the flowage and drainage can be controlled at will. Land that has been covered with stagnant water for a long time, as the bottom of ponds, is not fit for the growth of this plant until it has been cultivated and exposed to the air for a year or more.

Soil Adapted to It.- Wherever the cranberry is growing naturally one may be sure that the land near by is adapted to its culture. If no wild plants are growing near the supposed proper location it is a safe and good plan to plant a few rods of the most favorable portion of it as an experiment before spending much time or money on improvements which may prove to be futile. With a bog adapted to the growing of this plant, with control of the drainage and flowage, a good crop of fruit is assured for almost every year, if the work of preparation is properly done. Yet there are many wild and cultivated bogs that have yielded very profitable crops for many years where the flowage has not been controlled, and hence if that factor cannot be directed at will is not necessarily a sufficient reason why an attempt should not be made to plant suitable land, providing the work can be done at small cost. The returns from natural cranberry bogs may often be greatly increased by a little judicious expenditure.

Preparation of the Land.-The first steps should be directed to destroying the vegetation growing on the land. The proper method of doing this will vary according to the location and condition of the land. It can sumetimes be done by flooding the land for one year and then clearing it, or by summer fallowing, and it may occasionally pay to cut off the whole surface of the bog, with spade or turf ax, and remove it by hand. But in some way the surface of the land must be cleaned of its growth and made level, and fine and perfect as a garden. If it is to be flowed it should be made perfectly level, as it will then take much less water for flowage than if uneven. This matter is especially important where the water supply is limited.

Supplying Sand.-It is of great advantage to have the surface of the land covered with about four inches of clean sand, and 
this should be done even if at considerable expense. The sand used should preferably be rather coarse, but it must be free from clay or loam, as anything that encourages the taking of the surface of the bed is injurious. This sand offers a good place for the plants to root, is easily cultivated, and experience shows that it conduces to fruitfulness. Yet there are many very fruitful peat beds that have never been sanded. If a peat bed is to be used without sand the surface should be exposed to frost one year before planting or it will be likely to bake hard, but after one season's frost it becomes loose and fine.

Drainage and Flowage.-The method of securing these conditions will depend much on the situation of the land. The drainage is generally best accomplished by digging an open ditch four or more feet wide through the center of the land; a smaller ditch should completely enclose the land, which should be divided into beds by lateral ditches, about five rods apart. Where springs are met with they must be connected with a ditch.

Importance of Water.-The flowage may sometimes be controlled from a pond above the bog, or by a brook or creek running through it. Every reasonable effort should be made to secure and control water for flowage for the following reasons: (1) Without a good water supply bogs often get very dry in periods of protracted drouth, to the great injury of the plants, and occasionally peat or moss bogs get on fire and burn up, destroying all the work done. A bog once on fire can seldom be saved except by flooding. (2) The water kept over the plants in the spring will serve to retard the blossoming until danger of frost is past, and will protect the fruit from early frosts in autumn. (3) Beds that are kept under water untll late in the spring are seldom seriously injured by insects. (4) Beds do best when protected by a water covering in winter. If not thus protected they may be seriously injured.

Where there is considerable fall in the bed it is customary to finish it at several grades and to put in as many dams, but where there is not more than two or three feet of fall one dam is quite sufficient. Dams should be made strong and have sluice ways large enough to let off all the water liable to drain through them.

About Flowing.-All that is required in flowing a bog is sufficient water to cover the vines; they should be covered about the first of November, and as deep as they are to remain covered during the winter. The freezing of the vines in the ice does not hurt them, but raising the level of the water in the bed after they are frozen, and thus raising the ice and tearing the vines out of the ground, is where the great danger lies. To avoid this the sluiceways should be kept sufficiently open to allow any surplus water to pass off.

The first two seasons the water should be kept on the vines until the last of April, but after that, or when the bog is in condition to bear, the water sbould be kept on until the last of Miay or 
first of June. The object of keeping it on so late is to prevent in. jury from late frosts, and to destroy the fruit worm and fire worm, which are the worst foes of the cranberry. If the fruit is covered with water in warm weather it is very liable to be ruined, but the vines are uninjured by such flowage. Throughout the growing season the water should be about twelve inches below the surface of the bed.

Plants and Planting.--In selectlng plants great care should be used to get them from fruitfu' beds, as some are almost barren. There are very many named kinds, and they vary greatly in size, growth, time of ripening and productiveness, but it is doubtful if any of the named kinds, the most of which have originated in the East, are adapted to the climate of this section, and it is probatly bet'er for the present to depend on getting plants from the most fruitful wild cultivated beds near at hand. The kind most esteemed at the East is called the Early Black. It is very early and productive, though not a vigorous grower.

The cranberry plant grows very. readily from cuttings, and on this account slovenly growers sometimes cut the plants in a hay cutter, sow the pleces broadcast and harrow them in, but that method of planting is not advisable. The most common way is to make cuttings of the younger parts of the vines about ten inches long, and plant three or four together, as shown in Fig. 43, but sometimes longer cuttings are used which are doubled when planted. The cuttings may be carried over a whole season with good success, if

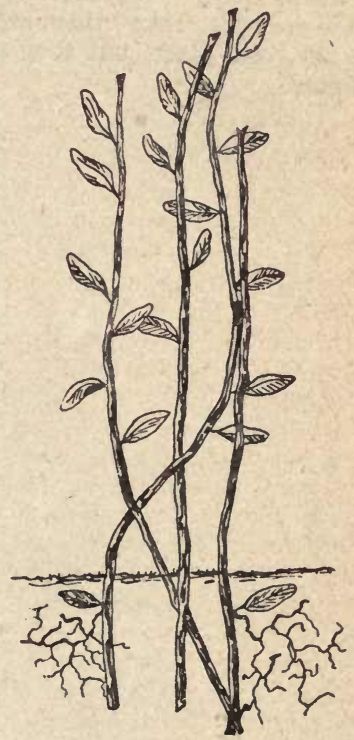

FIG. 43 -Showing method of planting cranberry cuttings. they are kept covered with running water, but in stagnant water they would be likely to spoil. On this account they may be set at almost any season of the year if the flowage is controlled, but the spring of the year is generally preferred, and if there is no chance to flow at will it is by far the surest time to plant.

Before planting is commenced the bed should be marked off each way at eighteen inch intervals. In planting, a wooden dibber is used having an incurved or reversed wedge-shaped point, with which the cuttings are crowded through the sand down into contact with the bog beneath at one operatlon, without first making a hole as is customary in the ordinary use of a dibber. After the 
cuttings are planted the water should be raised in the trenches sufficiently to keep the surface land a little moist to encourage the rooting of the cuttings. The after cultivation consists in keeping the soil moist and giving clean cultivation.

Picking.-If the berries are allowed to fully ripen on the vine they will keep much better than if picked earlier, but where there is danger of frost before they are ripe the berrles should be picked as soon as they commence to color, though when picked thus early they will seldom keep well after the middle of January. If severely frozen the berries are ruined, but they are not injured by a "white frost." Picking is generally done by hand, though some few growers "rake" them off the vines. The berries keep well in a dry, cool place, but they are more easily kept if covered with water. 


CHAPTER VI.

\section{DWARF JUNEBERRY.}

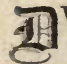

WARF JUNEBERRY (Amalanchier Canadensis, variety oblingifolia.) This is also called shad bush and service berry. There are several so-called varieties of it found in the northern states, one of which makes a small tree, but it is better known in its dwarf form, which is so very distinct from the tree form as to seem quite worthy of being made a separate species. This latter

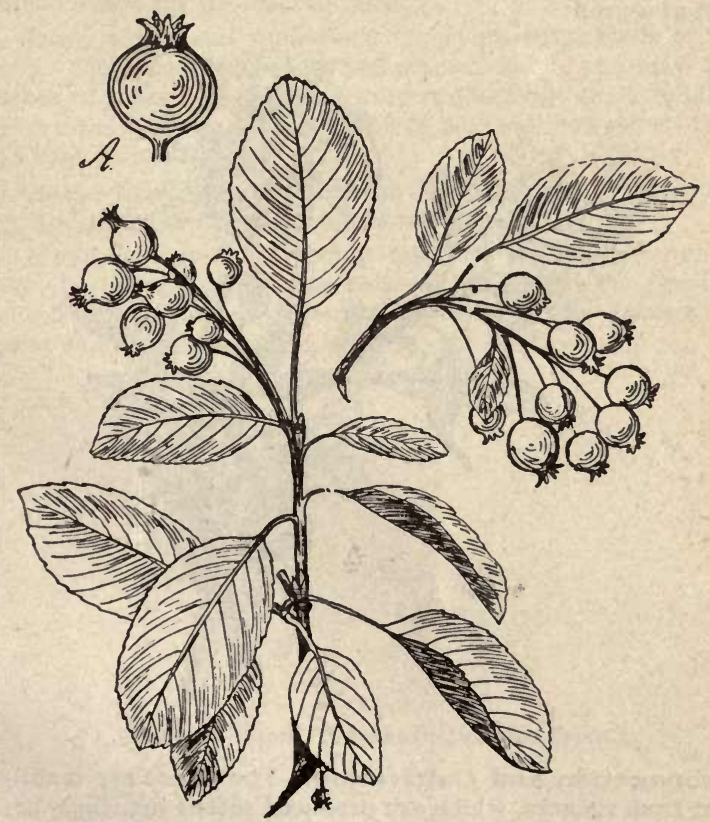

FIG. 44.-Foliage and fmit of Dwarf Juneberry, about one-half natural size. A, Fruit natural size. 
form is quite abundant and occasionally very productive. It is the selected kinds of it that are cultivated for fruit. It generally grows from four to six feet high; is covered with a profusion of white flowers early in the spring, and ripens its fruit in July with the raspberries. The berry is of a purplish red color, often nearly one-half inch in diameter. Figure 44 shows its size and form. Like the blueberries, the quality of the fruit is sweet though rather tame, but by the addition of a little lemon juice it makes an excellent pie or sauce. It is readily cultivated and yields regular and abundant crops. However, when grown in a small way the fruit must be protected from the birds or they will take it as fast as it ripens. Mosquito netting, or the coarse wire netting-such as is used for chicken yards-is useful for this purpose. When grown on a large scale the depredation of the birds is not so apparent. The plants are extremely hardy, seldom if ever being injured by our most severe winters, and are healthy and free from insect pests. On account of its many good qualities it should find a place in the home garden, and it could often be cultivated for the near market at a profit.

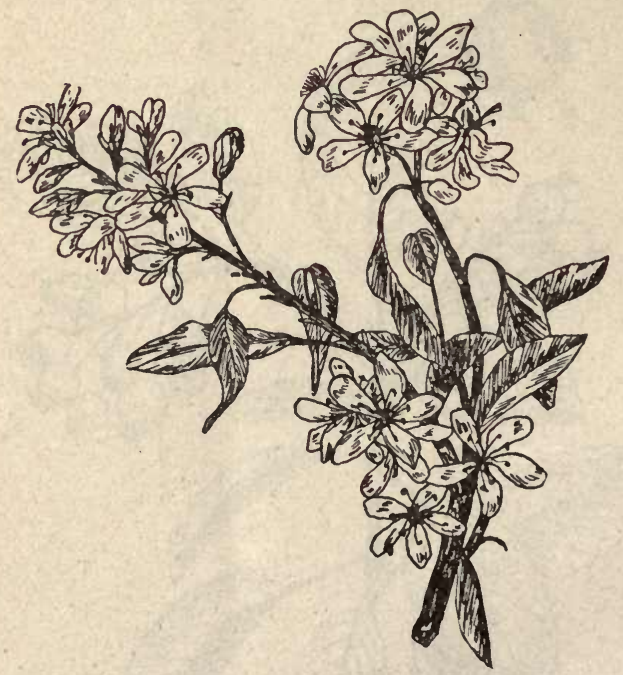

FIG. 45.-Full size flower's of Dwarf Juneberry.

Propagation and Cultivation.-The plants are readily increased from suckers, which are produced rather sparingly around the old plants. These should be set out at about four foot intervals in rows five feet apart, on rich upland. They commence to bear in two years, but will not produce a full crop until the fourth year. 
They need clean cultivation, and in dry situations should be mulched to protect from drouth. They require but little pruning, though the suckers should be thinned out if they become abundant.

Varieties.-There are but few varieties of this iruit offered by nurserymen, and these are the result of selections made from plants growing in the wild state. They are, however, much superior in size of fruit and in productiveness to the plants commonly found in the fields, although these latter are greatly improved by cultivation. It is very probable that by growing seedlings new varieties much superior to those now known will be originated. The kinds now grown require several weeks in which to ripen their fruit. The varleties that have been grown long enough to give them a fair trial are as follows:

Success. - This probably originated in Kansas. It is productive of large purple fruit of good quality; rather spreading in habit, with pendulous fruit clusters. Earlier than the others mentioned, ripening about with the early currants. Probably as good as any if not the best for general cultivation.

Chester Center and Alpina are strong growing kinds of decided merit. They are rather close and erect in habit, and may attain a heighth of seven or eight feet; very productive; fruit reddish purple; fruit clusters more erect than in Success; season a little later than that variety.

Osaqe.-Resembies the Success in habit but is not so productive, and is the latest of the kinds mentioned.

Aside from its fruit producing qualities the Dwarf Juneberries make nice lawn shrubs, being clean in habit and very pretty when covered with their profusion of graceful white flowers, which appear early in the spring. See Fig. 45. 


\section{CHAPTER VII.}

\section{SAND CHERRY.}

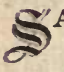

AND CHERRY (Prunus pumila). This fruit plant is found in Northern Michigan, Wisconsin, Minnesota, the Dakotas, and elsewhere. It is especially fruitful even in the most severe situations. It frequently fruits prodigiously in dry, gravelly embankments where scarce any other plant can find existence. In fact it seems to be better adapted to a very dry than to a moist location. In my experience with it plants from rich, moist land have flowered profusely but have failed to set much fruit. It

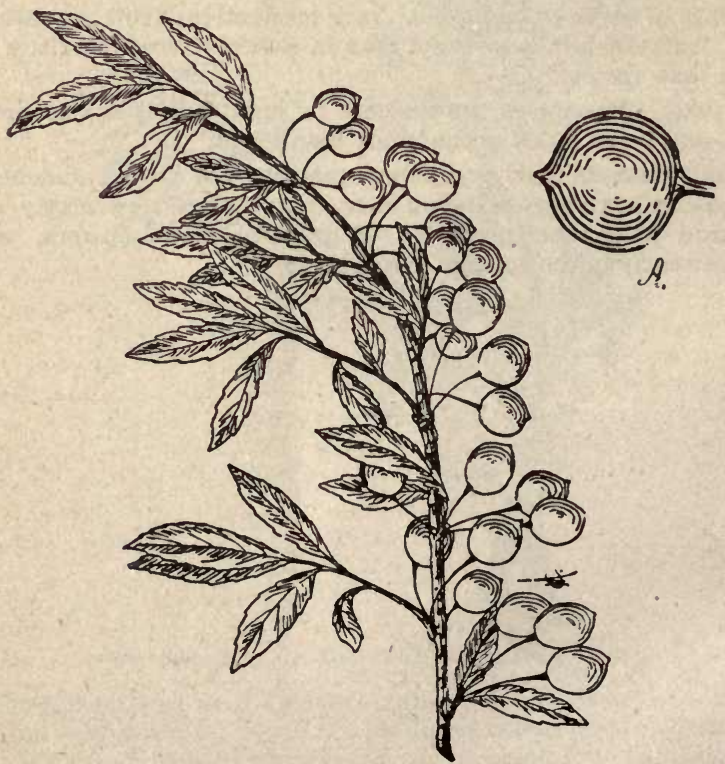

Frg. 46 - Foliage and fruit of Sand Cherry. A, Fruit natural size. 
seems quite probable that where the rainfall is light this plant will do well on rich soil, but where the precipitation is abundant it is best adapted to sandy or gravelly land. Thus it fruits abundantly on the sandy land of Northern Minnesota and on the dry, rich land of the Dakotas. See Fig. 46.

Description.-Some plants will reach a helghth of four feet and spread five feet on the ground, while others will scarce attain to half that size. The fruit resembles the cultivated cherry, but varies considerably in form, size and color on different plants. It is generally of a reddish-almost black-color when ripe. The ripe fruit varies from the size of a large green pea to five-eighths of an inch in diameter. In some the pit is small, while in others it is very large. The quality is generally too astringent to be relished uncooked, but this quality varies greatly in the different plants, some being fairly palatable. When cooked its astringency disappears and it makes a most excellent sauce. Where it grows abundantly it is used for sauce and for a sort of wine, which is said to be very palatable. It is not only a productive fruit plant, but a clean, strong growing shrub, and well adapted to severe locations on the lawn. The fruit ripens in the latter part of July and first of August. It seems to be much more like a plum than a cherry, and perhaps the name sand plum would be more appropriate for it.

Propagation.- It grows freely from seed, which should be sown as soon as ripe and not be allowed to get dry. Seedlings vary much, and selected plants should be grown in other ways. They fruit in about three years from seed. In many sections the wild plants may be dug and transplanted to the garden. Plants may be increased by layers, suckers and from root cuttings, and by budding and grafting on the sand cherry or the native plum. The easiest way to.increase them is by cutting the roots around the plants but eight inches away from the main stem sometime when the plant is dormant, and all the cut surfaces will sprout and form new plants. If the roots are cut into pieces about six inches long, and these treated like willow cuttings they will grow nearly as readily. When budded on the plum peculiar looking, interesting trees are formed, which are quite fruitful. The plum may also be worked on the sand cherry and it forms a good union, but the roots are so very flexible that the trees are liable to blow over unless the union is set very deep. The common cherry does not take freely on it. At present only seedlings are offered by nurserymen, there having been no named kinds introduced.

A form of this called the Dwarf Rocky Mountain cherry has recently been sent out from Colorado, but has not been sufficiently tried to warrant conclusions as to its value here. It is, however, extremely doibtful if it is any better than the best of our native kinds. The Utah hybrid cherry somewhat resembles this but has a more erect habit. A quite limited experience seems to show it is much inferior to our best native kinds. 
CHAPTER VIII.

BULLBERRY, OR BUFFALUBERRY.

IRULLBERRY, or BUFFALO-BERRY (Shepherdia argentea). 2 This plant is found abundantly along the river banks and coulees of the Dakotas, Montana, Wyoming and Idaho, though but sparingly, if at all, in Minnesota or the more eastern and central states, yet it grows freely and fruits abundantly in all the northern states. (Fig. 47.)

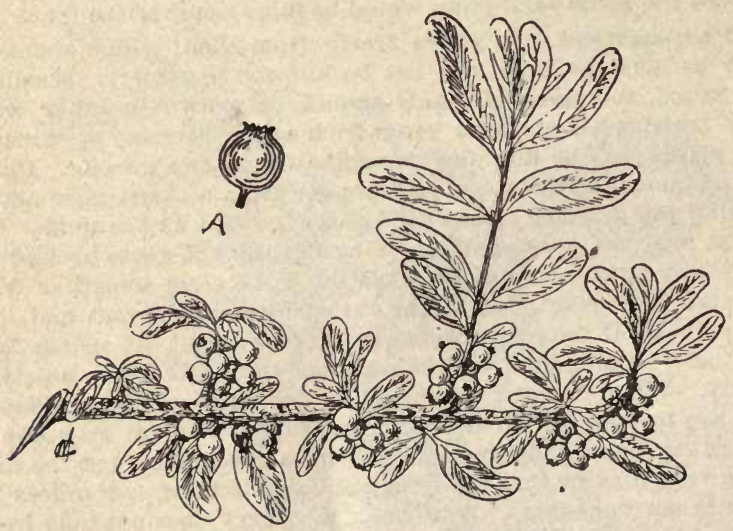

FIG. 47.-Foliage and fruit of Buffalo-berry; ont-half naturul size. $A$, Fruit natural size.

Description.-A small tree or shrub with light colored follage and young growth and opposite leaves. The flowers and fruit are clustered near the base of the small branchlets on spurs on very short stems. The plants are diøecious, $i$. e., one has pistillate and the other staminate flowers, so that it is necessary to have both kinds near together in order to get fruit. The flowers appear 
very early in the spring before the leaves, and are small and inconsplcuous. The fruit is produced in great abundance-often so thickly as to conceal the branches on which it grows,-and when
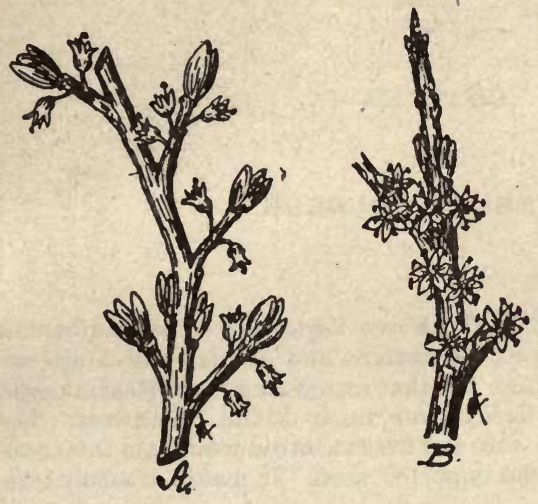

FIG 48.-Flowers of Buffalo-berry. (a) Pistillate flowers; (b) Stariinate flowers. About natural size. ive and reliable; but it is an elegant ornamental shrub, and it will probably be used to quite an extent for this purpose. (Fig. 48.)

Propagation.-This plant suckers readily if the roots are cut, but it is generally grown from seed, which germinate readily if not allowed to dry and is winter covered with earth and sown in the spring. An easy way to winter it is to cover the seed on the surface of the ground with an inverted sod. appearance to the whole plant. Occasional plants have yellow fruit. It is a bout the size of red currants, and contains one oval, quite large seed. The quality is very good, even of the best. It makes a fine jelly, but on account of the large seeds it is not so desirable for a sauce as red currants, and it is doubtful if it will ever be popular for fruit where the red currant is product. ripe gives a scarlet

(n)


CHAPTER, IX.

RUSSIAN MULBERRY.

GIIUSSIAN MULBERRY (Momus Tartarica). The mulberries 2 commonly grown in the eastern and central states are not hardy in this section, but that introduced from Russia under the above name is very hardy over much of the Northwest. The Menonites of Nebraska were the first to introduce it into this country, and they grew it from imported seed. It makes a smali tree, but is much better adapted to being grown in the form of a hedge or windbreak. In this form it will often attain the height of twenty feet and become very close and pretty if given an occasional pruning. It is of very rapid growth. (Fig. 49.)

Hardiness. - It is very hardy in Southern Minnesota and Southern Dakota, and even north to the latitude of St. Paul it stands fairly well. Occasionaliy in very severe winters it will lose a part of its new growth, but it quickly outgrows any in-

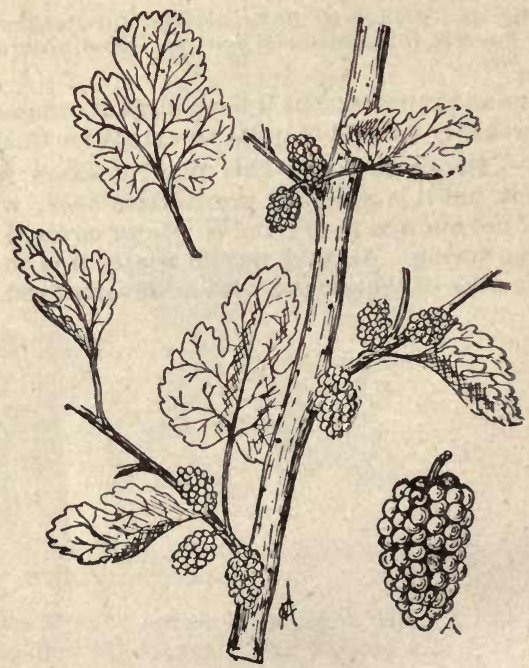

FIG. 49-Russian Mulberry, shoiving foizage arid fruit, reduced aoout one half natural size. (a), Fruil natural size jury and it is less liable to winter-kill when old than when young. 


Its Fruit.-With very few exceptions all the trees of this now growing in this country have been propagated from seed, and as with most other fruits, not one seedling in five hundred produces fruit of value. Most seedlings have very small fruit, while others are staminate and have no fruit at all. Quite frequently some trees will bear fruit as large as a medium-sized blackberry, and occasionally considerably larger. The quality of the fruit varies nearly as much as the size of the berries; some being insipid and even unpleasant, while others are sweet and agreeable, but like all mulberries, they lack high quality. They are quite soft when ripe and quickly fall to the grounc, which should be kept smooth so that they may be readily gathered. It is at its best just as it falls from the tree. It generally commences to ripen just before the first currants, and continues ripening for a week or more. It generally resembles the blackberry in appearance, but the fruit of some seedlings is nearly white in color, though the latter are seldom, if ever, as good eating as the black. The age at which plants commence to produce fruit varies greatly, but when five or six years old they may be expected to commence fruiting, and as they grow older their fruitfulness increases. As a market fruit it probably has no value, but a few trees should be in every garden. Children generally relish the fruit, and the birds let other fruit alone to feed on it. It is also used for sauce and pies, but for this purpose something should be added to it for flavor.

Propagation. - The seed grows readily if sown as soon as ripe. For this purpose the berries may be crushed in dry sand and sown with it in a rather moist, somewhat shady situation. In two years the seedlings may be transplanted to the permanent location, but these vary much in their productiveness, and while for a wind-break they many answer as well as any, yet when plants are wanted for fruit they should be grown from cuttings or layers of the best kinds, or by grafting on seedling stocks. For this purpose the cuttings should be made in the fall, about twelve inches long of the old wood, and be deeply planted in rich land, with not more than two buds above the surface. The branches root easily when layered, and if the earth is drawn up around the sprouis until they root they make good plants.

Varieties.-There are no named kinds offered by nurserymen, and it is necessary to depend on chance seedlings. However, if any large wind-preak is looked over in the fruiting season one or more trees can generaliy be piciked out that bear fruit of exceptional vaiue, and such may readily be increased. The flowers are of two ikinds; sometimes both staminate (male) and pistillate (female) are on one tree, and sometimes a single tree is limited to one sex. On this account some care is necessary in selecting a variety to get one with both kinds of flowers, or else plant the pistillate kind near a tree having staminate flowers. 
CHAPTER $\mathrm{X}$.

\section{THE APPLE.}

M] $\mathrm{HE}$ APPLE is a native of Northern Europe and Asia. Its botanical name is Pyrus malus. The crab-apples have descended from the wild Pyrus baccata of Siberia. These two species readily hybridize, and there are quite a number of varieties of the apple in cultivation that show the characteristics of both species. The American native crab-apple (Pyrus coronaria), so abundant in some sections, seems to be poorly adapted to cultivation. It often blights badly in its wild state, and when exposed in the orchard is not nearly as hardy as the hardier kinds of cultivated crab-apples. There is, however, one variety (the Soulard) belonging to this species, that is cultivated to some extent.

This is the most ancient and also the most highly esteemed and valuable of cultivated fruits. It reaches its highest development in tree and fruit in cold climates, yet in extremely cold situations it seems to be somewhat beyond its limit and to require sperial care to make it profitable. Many of the failures which have attended the planting of apple trees in the northwestern states need not be repeated if the subject is given careful study before new plantings are put out. It is far better that one should be entirely ignorant of the subject, but come to it with a desire and intention to learn every detail, than that he should undertake it with the belief that his experience in Eastern orchard methods and varieties is sufficlent to gulde him in similar work here. The methods and varieties adapted to Eastern and Southern orchards do not hold well here, and the following out of such methods, and the use of such varieties as are used there, has generally led to fallure and discouragement, and to the often heard remark that "apples cannot be successfully grown here."

Among those who have given this matter the most careful attention there is a well grounded belief that this section will eventually raise all the apples that can be used within its borders, and that too of varieties adapted to every season. The season of 1892 saw the markets here abundadtly supplied with the Duchess of Oldenburgh apple, and many car-loads of it were shipped to 
adjoining states. The large crop in that year resulted from its being a favorable season, and also from the fact that after the severe seasons of some ten years previous, which proved the great value of the Duchess of Oldenburgh, it was largely planted, and these plantings had just commenced to come into heavy bearing condition in 1892. There is every reason to believe that several other varieties will prove even more widely adapted to general cultivation here than the Duchess of Olden burgh.

In this section apple trees are not so long lived as in a somewhat milder climate, but they come into bearing much earlier and are very productive. The profits from properly planted orchards here are far in excess of those realized from Eastern orchards, and orcharding in some parts of this section offers a good field for profitable investment. The reason for this is found largely in the superior quality, higher color and generally brighter appearance of our fruit, and the proximity to good markets, together with the fact that our summer and autumn varieties do not come into market until the great rush of early Southern shipments has ceased and the winter kinds have not commenced to come in.

Locations Especially Adapted to Orcharding.-While apples will undoubtedly be grown in the near future to some extent over the whole of this section, yet at present the facts will only warrant their being planted on a commercial scale, in favorable locations south of the latitude of St. Paul, and in other locations where the climate may be much equalized by bodies of water and other modifying conditions. There are many excellent locations for orchards on the high rolling land and admirable soils in this section.

Loeation of the Apple Orchard.-The best location for an apple orchard is on high northern slopes, tipping down to the northeast, and the steeper the slope the better, providing it does not interfere with cultivation. The northern slope is preferred because it is least affected by drouth, by sudden changes in temperature, and by drying winds, which very uniformly come from the south. However, some excellent orchards in the Northwest are located on southern slopes. It is important to plant apple trees on the highest land available. If the elevation is not more than ten feet above the general level of the adjacent land it is a great advantage in furnishing air, drainage, equalizing the temperature in summer and lessening the danger from frost in the blossoming period.

The Worst Location for an Orchard is what is called a warm, sheltered spot, where the sun has free access and the winds are entirely shut off. Into such a:place the cold air from surrounding higher elevations settles at night, and while it is the hottest place during the day, it is the coldest at night. Blight and winter killing are apt to be abdndant in such places. In some sections,most generally those protected by water, forests or wooded hillsbut little if any difference is to be noticed in the growth and pro- 
ductiveness of trees on the various exposures, while in exposed places this difference is very marked.

Wind-breaks. - A free circulation of air is very desirable in an orchard, and full exposure is better than shutting in too closely, yet in a full exposure is not found the best condition for a successful orchard. It should be surrounded with wind-breaks on the exposed sides, sufficient to somewhat break the force of the wind, but not heavy $\in$ nough to prevent a good circulation of air through the orchard at any time. It is much 'more important to have a wind-break on the south"and west sides of an orchard, than on the north or east, for it is from the former directions that come the most injurious winds.

The I Land Best Adapted to the Growth of Apples in this section is what might be called a deep, open, clayey loam, that is well drained, either naturally or artificlally, and does not suffer severely from drouth or excess of water. But the apple may be grown successfully on almost any soil, even on that which is dry and gravelly; but the orchard requires more careful management in severe situations than in those that are favorable.

The land must be retentive and rich in plant food, for it is impossible to raise good fruit on poor soil. Sufficient moisture can generally be secured by heavy mulching, and the newer soils of this section are generally rich enough for apples without manuring; indeed, heavy, black prairie loam is generally so rich in plant food that it stimulates in most varieties of apples a late growth, especially when the autumn is warm and moist, and oniy the hard'est kinds, isuch as do not make a late growth in autumn, should be planted in such locations.

If the sub-soil is such very hard clay that the roots can scarcely penetrate, if at all, very deep plowing should be resorted to; but as this cannot go deep enough to give the roots much of a chance in very hard, dry clays, the holes should be dug very deep. $A$ better way than digging holes into such hard pan is to explode a medium charge of dynamite in it, which will so loosen it that the roots can penetrate. In some locations such treatment will make all the difference between success and failure.

Trees should be selected that are vigorous and healthy, with plenty of strong roots (Fig. 50). It is really of little importance as to the size or form of the top of a tree, providing it has good roots, and is healthy and free from blemishes; for if vigorous the form of the top may be readily changed. The best trees are those not over four years old, that have made moderate and not a rapid growth in the nursery. Three-year-old trees, of most varieties, are generally the best to set. Two-year-old trees do very well, and are often as good as any. Those one year old are too small to conveniently cultivate around in the field, and are better off in the nursery for another year.

Seedlings.-Apple seed grows readily and generally forms plants about twelvel inches high, with a tap-root of about the 
same length, the first season. The seed does not re-produce in quality the fruit it was taken from, and probably not one seedling in a thousand would be as good as any of the better cultivated kinds. Seedlings, however, are raised in large quantities, to be used in grafting, to increase the named varieties. Apple seed is generally obtained by washing out the pomace from cider mills. The seeds are heavier than the pulp and are readily separated from it by water. It is best not to allow the seed to get very dry, and on this account some growers prefer to sow it in the fall shortly after cleaning, while others mix it with sand and keep it buried in the ground until spring. If the seed gets very dry it often fails

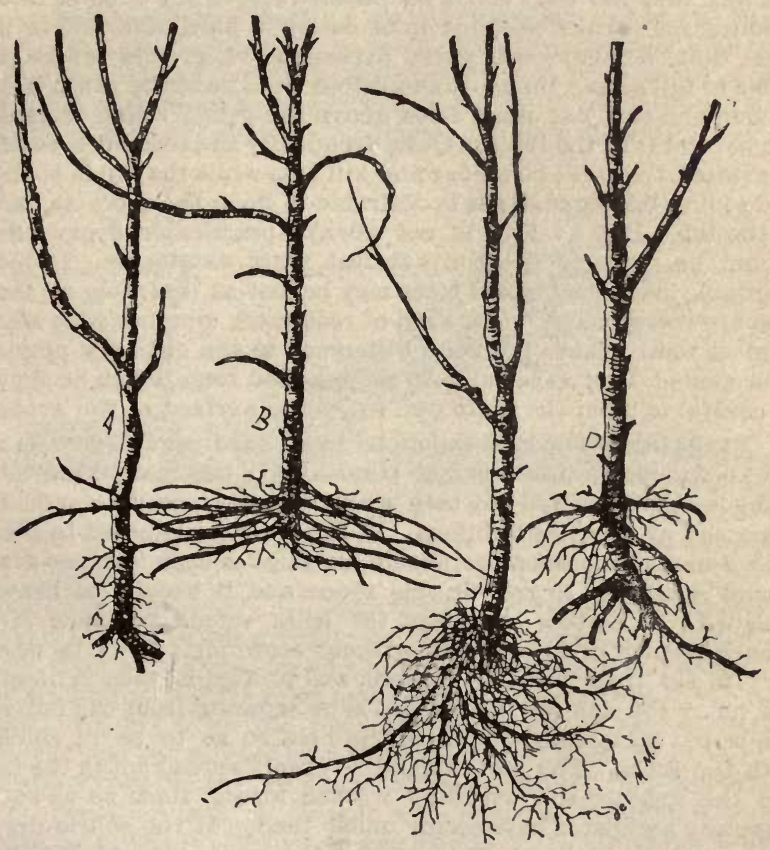

FIG. 50.-(A) Tree with very poor roots, which were spoiled by being cut off too short in digging. A common form.

(B) A well rooten tree with all the roots coming from the scion. The original root in which the scion was set has been broken off. An uncommon form.

(C) $A$ well rooted tree with fibrous roots. Such roots grow well if carefully spread out when planted. An uncommon form.

(D) A well rooted tree properly dug, leaving some roots from the 8 cion. A common form. 
to start, or does not start for one year, unless scalded or mixed with moist sand and allowed to freeze and thaw a few times. In a small way the seed may be kept mixed with sand and buried in a box in the ground until spring, when it should be put in a warm place until it starts into growth a little. It should then be sown in drills three inches deep and about three feet apart, in rich, warm soil, sowing about twenty seeds to the foot

Root-grafted Trees should always be preferred to those that are budded, for this section, unless in the case of hardy trees that are already once root-grafted, and are budded to change the bearing qualities, when budding is as good as grafting. The objection to budded trees is not to the method of propagation, but from the fact that the buds must be inserted above the ground into a seedling root, which seedling is of doubtful hardiness, and is per haps quite tender; yet is partly exposed above ground, where it is liable to fail at any time. Root-grafted trees have the graft below ground and send out roots from above the graft, which increases the hardiness of the trees. Quite frequently the roots of a budded or grafted tree will be tender and kill out, while the top is healthy and sound; consequently it is desirable to have the roots as hardy as the top. But as this is not always practicable every effort should be made to get the hardiest roots obtainable. In more favorable locations budded trees may be just as desirable as those that are root-grafted. The kind of root-graft, whether with whole or piece roots, makes but little difference to the ordinary planter, who should look especially to getting good trees, when he should be careful to plant the graft well below the surface of the ground.

Planting. - The land should be in as good condition as is re. quired for corn. The work of planting will be greatly facilitated if the land is furrowed out both ways with a large plow, and the trees set at the intersections. If the trees must be set in sod, a hole five feet in diameter should be dug for each tree; no grass should be allowed to grow in this space, and it should be heavily mulched. In setting the trees the holes should be made large enough to take in all the roots without crowding. If it is necessary to set trees into the sub-soil, and it often is, then in digging the holes the top-soil should be kept separate from the sub-soil and be put back in the bottom of the hole so as to be in contact with the roots. The roots should be evenly spread out in the hole and the fine top-soil carefully worked among them so as not to leave any air spaces between or under them. If the soil is dry it can hardly be made too solid around the roots. If wet but little pressure should be used.

The Time to Plant.-In the north apple trees should never be set in the fall of the year, nor should they be dug from the nursery rows in the spring, as they are very liable to be weakened; if not seriously injured by the winter if left exposed. They should be dug in the autumn and buried root anc branch - "heeled in"- in dry soil until spring, or else be carried over the winter in a cold 
cellar, with their roots buried in soil. As few cellars are fit for this purpose it is generally safer to bury them outside. As a rule it is best for planters to get their trees in the fall, as they are then more certain to get good stock, and there is no delay in waiting for them to come in the spring. The trees may be set as soon as the soil works easily in the spring, and until the trees break into leaf. As a rule moderately early planting gives the best results, but trees should never be set in wet, sticky soil.

Heeling In is a term used to designate the temporary burying of the roots of trees or plants in earth or other material. If the trees are to be moved again in a few days a very light covering will be sufficient; but if they are to remain several weeks much care should be taken to do the work well. To begin with, select a dry, mellow plece of ground; dig a wide trench, put in the treesa few at a time-either in an erect or sloping position, and cover them so deep and firm that they cannot dry out. If apple or other somewhat tender trees are to remain heeled in over winter it will be found best to commence by digging a trench about two feet deep

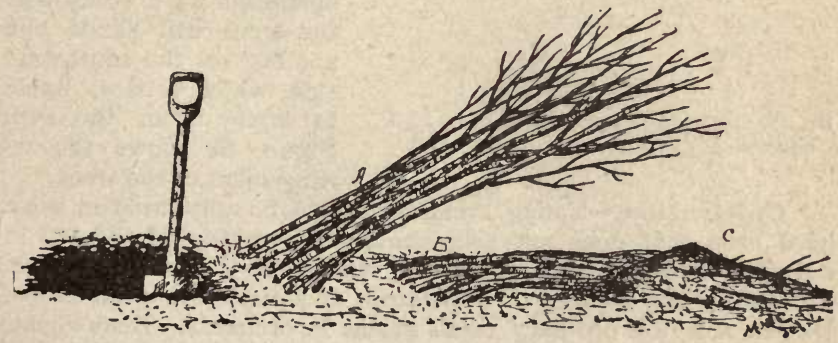

Fig. 51.- Various stages of the operation. A, Row of trees with roots covered; $B, a$ row bent down and the tops covered with earth at $C$.

and three feet wide in dry land, where no water will stand in the trenches; put in a layer of trees sloping; cover the roots with a thin layer of fine, mellow earth, filling in carefully and solid all the interstices among the roots and stems; continue thus until all the trees are in, when the tops and all should be bent down to the ground and entirely covered with about six inches of earth. Figure 51 shows the various stages of the operation. ( $A$, Row of trees with roots covered; $B, A$ row bent down and the tops covered with earth at $C$.) The stems and all should be completely covered when the work is finished.

Depth to Plant. - In the best locations the trees should be set about four inches deeper than they grew in the nursery. In very dry, light soll they may be put twelve inches deeper than they naturally grew. On steep hillsides they must be set much deeper, or they will come too near the surface owing to the slope of the land. One of the most important objects secured by deep planting 
is the sending out of roots from the scion, for when trees are well rooted from the scion they are generally much improved in hardiness. However, in heavy retentive soil deep planting is not desirable.

Distance Apart to Plant.-Apple trees in cold regions should be set quite close to one another. In favorable locations they should be set further apart than when the conditions are very severe. Most varieties do best when not over sixteen feet apart; but upright growing kinds should be set closer. The Duchess of

Oldenburgh does very well

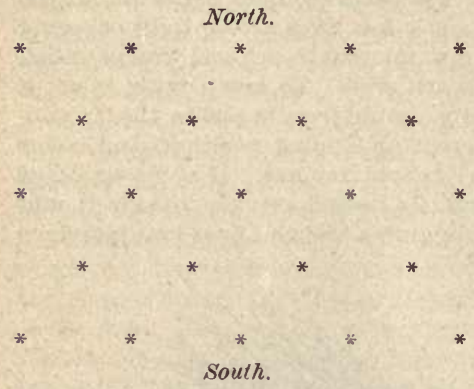

FIG. 52.-Asterisks showing desirable arrangement of the trees in the orchard. in severe locations when set not over twelve feet apart each way. 'The trees should be set so as to "break joints", north and south-that is, the trees in one row should be set opposite the vacancies in the next. If the rows run northeast a n d southwest the trees will shade one another on the southwest side, which is most liable to injury from the sun. Figure 52 shows the arrangement of the trees.

Cultivation.-Young orchards should be cultivated in some hoed crop that does not necessitate the working of the soil in autumn, but will keep the land well worked in the early summer. For this purpose corn, early potatoes or squash are good crops. Do not sow the ordinary small grains in orchards. Buckwheat, however, seems to be an exception to this rule, and on account of its dense shade is a very good crop for this purpose. After the trees begin to bear it is often a good plan to seed the land to clover, which should be broken up occasionally. The trees should be well mulched, and if they do not make a satisfactory growth should be well manured. When an orchard becomes "sod bound" nothing will do it more good than a drove of hogs sufficient to root up all the sod, but they must not be allowed to gnaw the trees. Besides breaking up the sod the hogs are very beneficial by destroying many kinds of insects.

Forming the Tree.-Whatever may be the shape of the tree when it is received from the nursery, it will need careful attention in the orchard. The question whether to grow trees with a long or a short trunk, is a much disputed one; but it may be laid down as a general rule that in favorable locations the trunks of the hardier kinds should be free from branches for fully three feet from the ground, but in such cases it should have some protection. In very severe and exposed locations, or in the case of somewhat 


tender varieties, it will be better to have the trees branch near to the ground (Fig. 53), since when so formed they are hardier and less exposed to the wind than if they have tall trunks. There is a constant tendency for our trees to incline to the northeast, and this should be prevented so far as possible. To do this the growth should be encouraged on the southwest side by light summer pruning on the north side. Also, in setting the trees they should be slightly inclined to the southwest, and an effort made to keep them in that position.

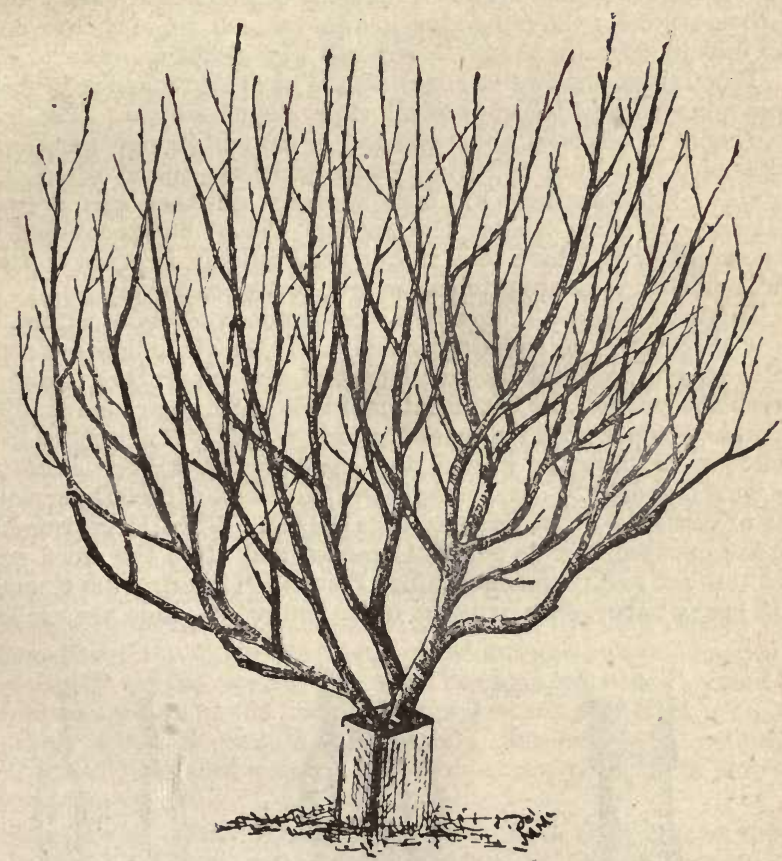

FIG. 53.-A low-headed tree with trunk boxed. Frorm and treatment adapted to severe locations.

Pruning.-In pruning it is well to remember that pruning in the summer checks growth, and pruning at suitable times, when the tree is dormant, stimulates growth. Pruning apple trees just as the sap is starting in the spring is a bad practice, and generally results in quite a portion of the pruned limb dying back or being seriously weakened. The best time to prune is in June, as then the wounds heal over at once. But if a very large amount of wood must be removed it would be better to cut it off in October, or dur- 
ing warm days in March, before the sap starts, as the removal of a large amount of foliage in June might give a serious check to the tree. Scions for grafting are generally cut in November. before severe weather. Very light pruning may be done safely at almost any time, except as noted above. If the work of pruning is properly attended to there will be no need of heavy pruning, and generally a little pinching or rubbing off of the growth in summer is sufficlent. In a northern climate it is better not to prune at all than to prune too much, and apple trees only need to have interlocking and straggling branches removed or shortened. They need all their wood for the protection it affords. All wounds over onehalf inch in dlameter should be covered with grafting wax.

When trees are received they should have all broken or bruised roots removed, and the ends of all roots cut off smooth. The top, too, should be cut back about one-half or more of its new growth to correspond to the loss of roots. Some varieties-the Wealthy, for instance-will sometimes kill back severely and then sprout from the roots. In such a case the sprouts should be encouraged to make a new tree, which they will do very quickly if given a little care, and then they are often more productive than ever.

Injured Trees.- One of the most common forms of injury to trees is girdling by mice or rabbits. If the girdling is not complete, even though only a small part of the inner bark extends across the wound, the best treatment is to bank up around it with earth, and this is good treatment for any wound. If injury of any kind is so far from the ground that banking up is impracticable, the wound should be covered with grafting wax and cloth, or with clay or cow manure, so as to exclude the air. When large wounds are left exposed they do not heal readily, and often the wood seasons through and permanent injury results. Covering the wounds with heavy paper, even without other protection, aids very much
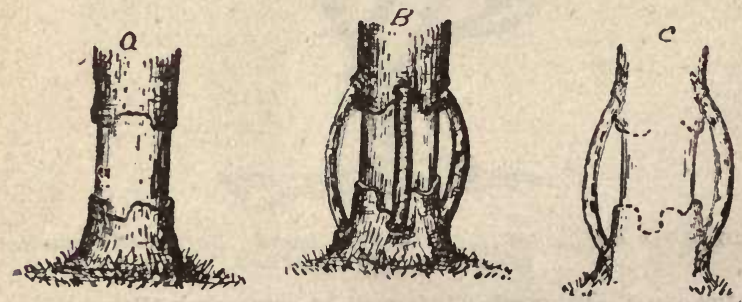

FIG. 54.-Girdled tree with wound bridged over. A, a girdled trunk. $B$, scions inserted; $C$, method of inserting scions.

in the healing process. Another way of saving girdled trees is to wait until the bark peels freely and then spring in scions long enough to connect the sound inside bark above and below the injury. The ends of long scions are cut all on one side and shoved under the bark as in budding (Fig. 54). The tree eagerly seizes 
upon this opportunity for making a connection between the root and top in the cambium layer, and the scions increase in size until finally they close up and make a covering as good as the original bark.

Mulching.-The advantage of a mulch around trees is not generally appreciated. It checks evaporation and prevents the running off of water which allows it to soak into the land. It helps to equalize the moisture in the soil throughout the growing season, and prevents root-killing in winter. It is of the greatest assistance in rather dry locations, where its use makes success possible with many varieties that otherwise would be complete failures. In almost any soil in the Northwest the chances of trees living and doing well would be increased by the use of a mulch around them, but this is especially true of sandy land and southern exposures. It is generally best to cultivate the land around trees when they are small; but if they are set on sod land, or after they begln to bear, or if they suffer from drouth, they should be heavily mulched at once, and this should be renewed as often as necessary, to keep a covering five or six Inches in depth on the ground at all times extending at least four feet on all sides from the tree, and in the case of larger trees extending out as far as the branches. This mulch may consist of any litter, straw, bagasse, hardwood sawdust, brush, weeds and grape trimmings, and even coal ashes are good for this purpose.

Manuring.-Young orchards are sometimes injured by too

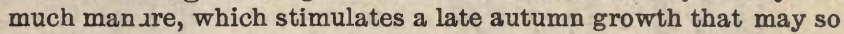
weaken the tree that it may be winter-killed. But if crops are grown in an orchard enough manure must be added to put back the plant food carried off in the crop. After trees begin to bear fruit they need manuring, and without it they are very liable to run out. All manures for orchards should be applied to the land during the time between the fall of the leaves in the autumn and their appearance again in the spring. In case the manure is -well-rotted it should be applied in the spring. Barnyard manure is as good as anything for this purpose. Some soils, however, will maintain their fertility without manure, providing a crop of clover is plowed in every few years.

Sunscald. - This is the name given to a condition of trees when the bark becomes dead on the southern or southwest sides of trees (Fig. 55). This is a very serious cause of loss of trees in high latitudes, and all trees should be protected against it. It is probably due to the action of the sun in starting the growth on the southwest side of the trees and then being suddenly checked by the cold. It is most liable to occur in the latter part of winter. Some varieties are much more liable to this trouble than others. Trees that incline to the northwest, so that the sun's rays fall directly on the trunk, are very liable to it. If trees are planted and kept inclined to the southwest until the ki anches shade the trunk, they will not be affected. Anything that shades the trunk pre- 
vents this trouble, and various means are employed to that end. Sometimes the trunk is covered with hay, straw, corn-stalks, burlap or paper, wire netting or laths wired together, or it may be shadec by a board set up on the southwest side. All these are good and answer the purpose, and many of them protect from mice, rabbits, and flat-head borers as well, if properly attended to; but one of the best is the lath screen, which is easily made, is cheap, durable and satisfactory.

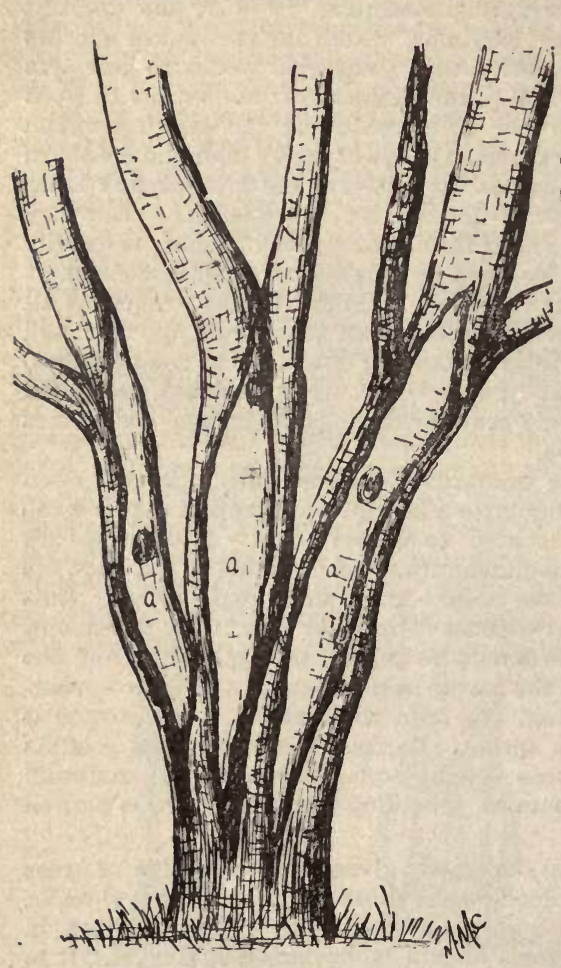

FIG. 55.-Sunscalded tree. $a, a, a$, dead wood.

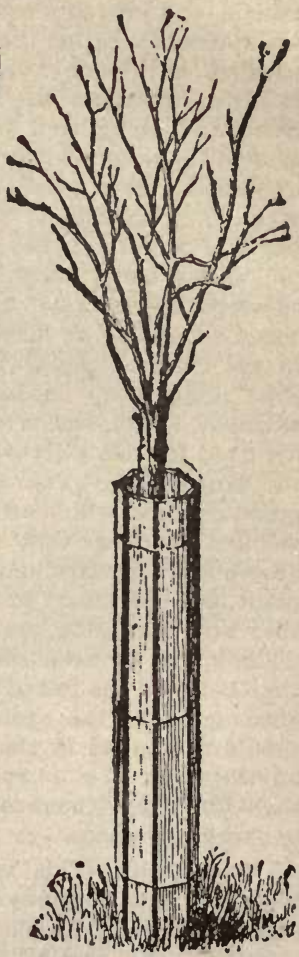

Fig. 56.-Lath screen in place around tree.

The lath screen protector is shown in Fig. 56. It is easily ard quickly made, but whether it will be cheaper to use than wood veneers will depend on circumstances. Each of these methods of protection secures immunity from sunscald, mice, rabbits and the flat-head borer to the part they cover, and also protect the bark from whiffle-trees. Six cr seven common laths and three No. 18 
wires are necessary to make the lath screens. The laths are left one-fourth of an inch apart, and the wire is simply crossed between the laths and not twisted. Methods of making it will readily suggest themselves. It may be made on a common work-bench by the device shown in Fig. 57, which is from an article by Prof. Goff, in the Wisconsin Horticultural Report for 1891. $\boldsymbol{A}, \boldsymbol{A}, \boldsymbol{A}$ represent nails in the bench to which are attached the wires. $B$, the first

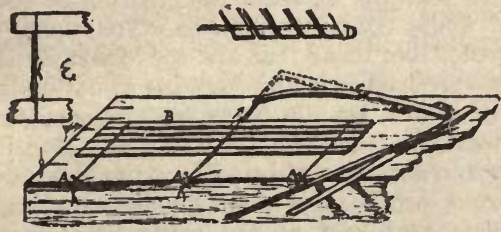

FIG. 57.-Showing method of making lath screen.

lath put between the wires and attached to the spring stick, $C$, which holds the wires taut while the other laths are inserted from the end, and these are always put under the lower and over the upper wires, thus crossing the wires. $E$ show the end of spring stick and part of first lath held together with a hooked wire. $D$ shows lath screen partly made. The laths should be long enough to reach nearly to the lower branches of the trees. A bunch of hay may be stuffed in at the top to keep the protector in place and keep it from rubbing the tree. The screens should be left on until the wires rust off. Tar or tarred paper should never be used in contact with the bark of apple trees.

Protection by banking up the trunks of young trees about one foot, on the approach of winter, as shown in Fig. 58, is a good practice. It protects the graft and is a sufficient barrier against mice, unless there is a deep fall of snow. This is not a very laborious matter, for about three spadesful of soil is enough for each tree. When there is danger of mice working under the snov trod it down quite firmly around the trees. To guard against mice and rabbits when not otherwise protected, wash the stems with thin whitewash thickened with copperas and sulphur. If this is washed off by rains renew the wash as often as necessary.

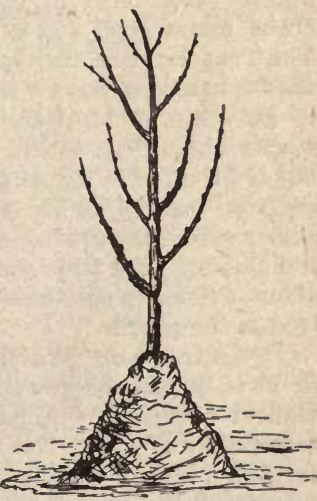

Protecting the trunks by box- FIG. 58.-Apple tree banked ing them up and then filling the boxes up for winter. with earth, as shown in Fig. 53, is a method that is well worthy of being adopted, especially by those who wish to grow apples in very severe locations. Such treatment protects the trunk from sunscald, mice and rabbits, and also from ürying winds, severc cold, 
and from sudden freezing and thawing, and commends itself in every way. The boxes may be kept filled with soil all the year around, but care should be taken that if the practice is to be discontinued that they are not taken off on the approach of winter, but in the spring. In more favorable locations such treatment is unnecessary with hardy kinds, but even in such places the good effect will be apparent.

Top-working.-By top-working is meant the grafting or budding of a tree after it is of some considerable size. The term is used to distinguish such trees from those that are root-grafted. It is here recommended for severe locations and for somewhat tender kinds, such as the Wealthy, which, besides being somewhat tender and liable to sunscald, is weak in the stem and crotches. If this variety is zrafted on the branches of the Virginia crab, which is a very hardy sort with strong crotches, a tree is formed that has much of the hardiness of that crab, but at the same time bears Wealthy apples. By this method we may increase the hardiness of trees to a considerable degree. Some varieties seem to be better adapted to one stock than to another. The Virginia crab is a stock that is hardy in every particular, and especially desirable for top-working. It grows rapidly, makes a large tree. and will keep up in rapidity of growth with any of our larger apples. But most of the larger growing crabs make good stocks for top-working. The Transcendent crab may be successfully used for this purpose. When it is intended to grow an orchard by this method the stocks should be set in the spring, to be budded the following August, or should be grafted the following spring. Figure 59 shows where the grafts should be made. If to be budded the buds should be inserted in about the same positions in the head of the tree as the grafts.

Picking and Marketing.-In order to have apples keep well, or command the highest price, they must be hand-picked before they are fully ripe and handled very carefully. They should never be shaken from the trees, for although they may not FIG. 59--Top-icorked tree. show the bruises at once, yet they will

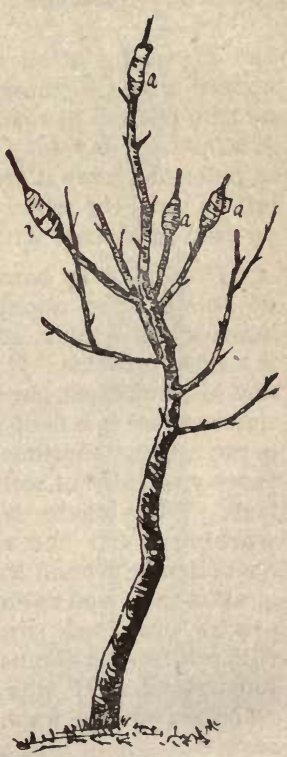
show plainly in a few days, and cause premature decay. This is especially true of the Duchess of Oldenburgh, and other varieties which, like it, easily become spotted. They should be carefully sorted into three grades-best, second liest, and culls. The latter grade had better be kept at home and fed to stock, or made into 
vinegar. If to be shipped to a distance apples should be packed in clean, new barrels, into whtch they should be pressed so firmly that they cannot move. If packed loosely they are almost certain to arrive in market in a badly injured or worthless condition. A regular press is made for this purpose and is sold by all implement dealers.

\section{Some Important Things to Remember Are:-}

(1) If the roots of trees are frozen out of the ground, and thawed again in contact with air, the tree will probably die.

(2) If frozen roots are well buried before thawing at all the tree will be uninjured.

(3) Manure should never be placed in contact with the roots of trees when they are set, but old puiverized earth compost answers well.

(4) Trees that are received in a shrivelled condition may generally be revived by burying, tops and all, with earth for a few days.

(5) If trees are to be watered in dry weather it is very im. portant that they have a heavy covering of mulch, otherwise the earth will be crusted over, causing the water to dry out rapidly.

(6) If watering is commenced it should be continued until rain comes, otherwlse it may be worse than no watering at all. As a rule heavy mulching is better than watering.

(7) A tree of small or medium size that is thrifty is much to be preferred, for transplanting, to one that is very large, but which will be checked in its growth by being moved.

Diseases.-BLIGHT. In order to be truly hardy and desirable for northern sections an apple tree should'be hardy against fire blight as well as the weather. This is the blight that kills the growing wood in the summer. It is due to the growth of a very small microscopic plant termed Micrococcus amylovorus. It is much the same as the germs of disease which attack animals. These germs are very light, are thrown off by the plant and readily blow about. They grow in and destroy the tissues of the tree. It is a very insidious enemy, and as yet we know of no method of destroying it or stopping its ravages. Some varieties, for reasons not known, are not subject to its attacks, while others are only slightly affected or only in occasional years. When it appears the best treatment is to remove and burn all the diseased parts as soon as may be, cutting considerably below where the disease appears. The only way to avoid it is to plant varieties that are not subject to its attacks. In pruning it should be borne in mind that the disease may be carried from a diseased to a healthy tree by the pruning implement.

ScaB (Fusicladium). - This is the disease that causes the scab or blotches that deface the skin of apples and destroys the leaves. 
It also attacks pears. Figure 60 shows the appearance of an apple affected with this disease. It not only injures the appearance of the fruit, and consequently its market value, but seems to dwarf its growth. It is only occasionally abundant in this state, and as a rule our hardy varieties are not injured by it. In case it becomes abundant it may be prevented by spraying the trees with Bordeaux mixture, made as recommended in the chapter on strawberries, but diluted by adding twice as much water. Spray the trees with it as soon as the first leaves appear; again just

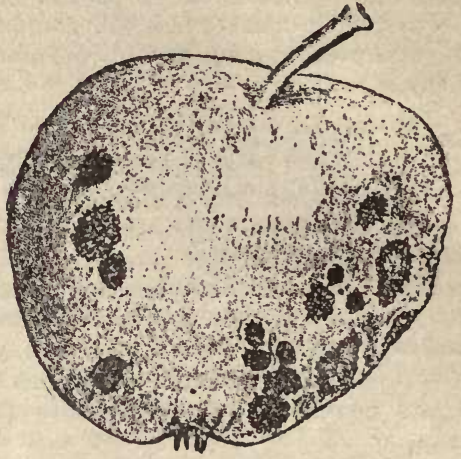

FIG. 60-Apple affected with scab. after bloom, and a third time two or three weeks later. If rains are frequent in June a fourth spraying should be given in the latter part of that month.

-Insects.-Flat-HeAded APPLE TREe BORER (Chrysobothris femorata). This borer is quite abundant in some sections, but generally does not cause serious losses here. It prefers to work in trees that are newly transplanted, or weakened by some disease, and makes its borings in the trunk and larger branches, often

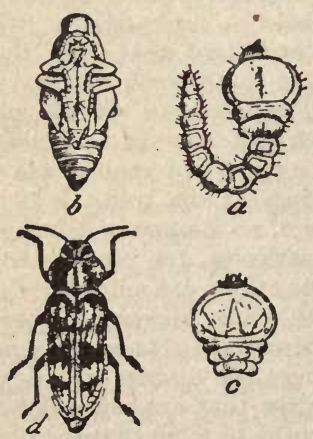

FIG. 61.-Flat-headed apple tree borer: a, larva (borer); $b$, pupa: $d$, beelle somewhat enlarged. finally out to the bark, where it changes
into the beetle form. Figure 61 shows the borer in its several forms. of a beetle which is oblong, flattish in form, and of a shining greenish-black color, about three-eighths of an inch long. The beetles emerge from the boring in the trees in the early summer. They are very active in the middle of warm days, and may be found in the hot sunshine running up and down the trunk of the tree, whence they fly quickly if an attempt is made to catch them. They lay their eggs, which are yellow, under loose scales on the bark, or in cracks and crevices. The young soon hatch and eat their way through the bark, feeding on the sap wood. As the borer approaches maturity it usually bores into the more solid wood, and Figure 61 shows the borer in its several completely girdling them. It is the larva 

REMEDIES.-All trees should be examined early in autumn, when, if there are borers present, they may be detected by the dry appearance of the bark, by the borings, or by the exudation of sap, or sawdust-like castings. When such signs are seen the parts should be at once cut into with a knife and the borer destroyed. As a preventive measure there is perhaps nothing better than to coat the trunk and larger branches with a mixture of soft-soap reduced to the consistency of a thick paint with a solution of washing soda, and if a little carbolic acid is added it will be even more repulsive to the beetles. This should be kept on the trees during the summer montbs, when this insect is injurious.

NEW YoRK WeEvil (Ithycerus noveboracensis). This is a very large snout-beetle of gray color marked

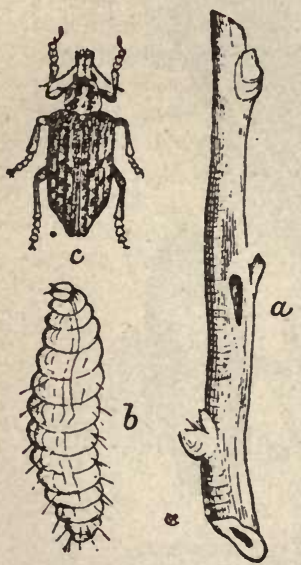

Fig. 62--Neiv York Weevil $b$, larva; $c$, beetle. with black, about one-half inch long. It breeds in the oak, and is only abundant where there are oak groves near by. In such locations it often causes great injury by gnawing out the buds early in the season, and later by cutting off the young shoots, so that the trees are destroyed or seriously injured. It attacks cherries and plums as well as apples. It seems to do its work at night, or early in the morning, for it does not work much if at all during the day. Figure 62 shows this insect in its different stages of growth.

REMEDY.-The only known remedy for this pest is to jar the trees, when they curl up and fall to the ground, and then may readily be gathered and destroyed. When the trees are badly infested they should be jarred once a day as long as any are found. They disappear about the first of July.

Tent Caterpillar (Clisiocampa Americana).-The characteristics of this insect are readily seen in Fig. 63, which shows the caterpillar resting on the outside of the tent-like structure in which they live, and also a twig sustaining a bunch of eggs. The habit of this insect is about as follows: The eggs are laid on the smaller twigs of fruit trees in ring-like clusters during the first two weeks in July. Two or three hundred eggs are laid in each cluster, and they are firmly cemented together. These hatch out early in the spring just as the leaves open. The young caterpillars soon commence to make a tent by extending sheets of web across the nearest forks of the twigs, and this tent or nest is enlarged as more room is needed. It has holes in it through which the caterpillars enter. The caterpillars retreat in the nest at night and in 
stormy weather, and usually when not feeding. They generally come out of their nest once in the morning and once in the after-

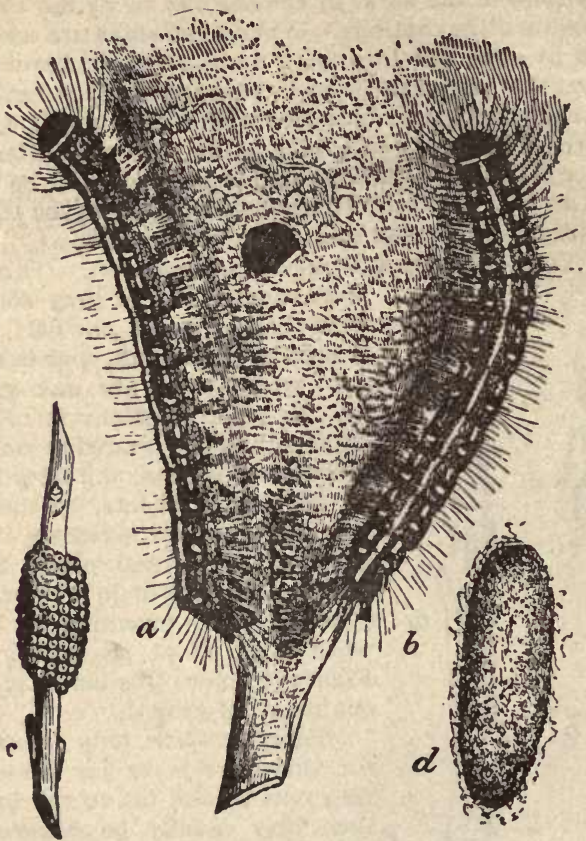

FIG. 63.-Early stages of Orchard Tent Caterpillar. $a, b$. Calerpillars resting on tent-like nest; $c$, ring of like egg mass on twig; $d$, cocoon.

noon to feed. They are very voracious, and soon strip the infested tree of its foliage. They change to moths (Fig. 64) in June and soon commence laying eggs.

REMEDY. - The tents are readily seen. They should be destroyed eariy in the season when the worms are within them. The egg masses are also readily seen against a cloudy sky, and are easily gathered and destroyed. Fig. 64.-Moth of Orchard Tent C'aterpillar. The foliage may be poisoned with Paris green, used at the rate of one pound to two hundred gallons of water.

The forest tent cateryillar, which has caused so much damage 
in this section some years, closely resembles the foregoing in appearance, but it builds only a very thin web against the trunk or branches of the trees, and they march in every direction. At night they collect in groups on the trunks and branches of the trees, where they may be easily destroyed. The egg masses resemble those of the tent caterpiliar, but as these are generally high up on forest trees it is impracticable to gather and destroy them. The best remedy is to poison the infested trees with Paris green, as recommended for the tent caterpillar.

Climbing Cut-Worm (Agrotis $s p$ ). - When the foliage or buds are being destroyed without any apparent cause, climbing cutworms should be searched for. They will be found buried in the ground near the base of the trees. They are closeiy allied to and resemble the common cut-worms, so well known to gardeners, and occasionally do much damage. They may be destroyed by spraying the foliage as recommended for the tent caterpillar and by jarring the trees after dark, having first spread sheets on the ground. Putting a cone-shaped piece of zinc or tin around the trce, so that they cannot gain a foothold on it, will keep them off the trees.

Codling Мотн (Carpocapsa pomonella).-Figure 65 plainly shows the work of this pest. It is the common cause of wormy

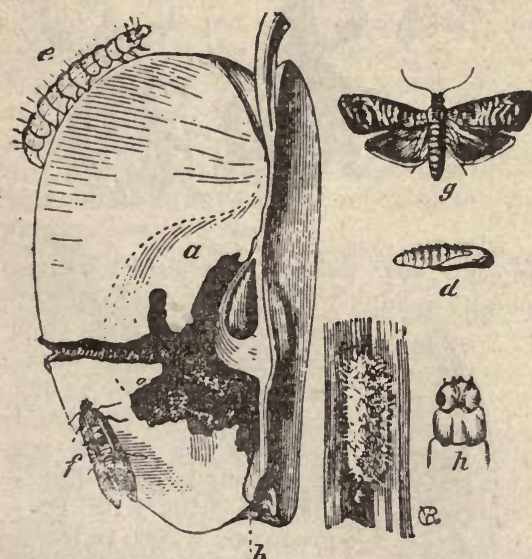

apples, and causes the infested fruit to ripen prematurely and fall to the ground. The moths deposit their egg s in the calyz or eye of the apple just as the blossoms fall. On hatching the worm eats into the fruit, where it lives until it is ready to change to the moth stage, when it leaves the fruit and spins a cocoon in which it undergoes its change. There are several broods in a season. The worms that are in the late apple leave them in the winter and find

Fig. 65.-Codling Moth a, Apple injuren by places to spin their coworm; $b$, calyx. end where the larva entered; coons near by, of ten bee. larva (worm) excapeng; $f$, moth at rest; $g$. same with wings spread; $d$, chrysalis; $i$, cocoon. staves of the barrels holding the fruit.

REMEDIES. - The fallen fruit should be promptly gathered and destroyed. Keeping hogs in an orchard is very beneficial. If 
bands of burlap, or even paper, six inches wide, are fastened around the trunks not later than the first of June, the worms and chrysalides of this moth will be found under them and may be easily destroyed. The bands should be examined about once in ten days until the last of August.

The most common way of protecting against this insect is by spraying the trees just after the blossoms fall, when the apples stand upright, with Paris green and water, at the rate of one pound to two hundred gallons. When the trees are sprayed to prevent scab the Paris green may be added to the Bordeax mixture at the rate of one pound to two hundred gallons of the mixture.

FALL WeB-Worm (Hyphantria textor). - This resembles the ordinary tent caterpillar in having a tent, but is smaller in size. It appears in the late summer and fall. It is quickly seen and easily destroyed by cutting off the twig on which the web is found and destroying the caterpillars, or by spraying the foliage with Paris green, as recommended for tent caterpillar.

Apple CURCulio (Anthonomus quadrigibbus). This is a snoutbeetle which cuts small holes in fruit as it feeds, and also as a place for its eggs. The latter soon hatch a small grub, about one-half inch long. The special injury to the fruit comes from the hard knots that form around the hole, which makes the apples gnarled and of poor quality. (See Figs. 66 and 67.)

REMEDY.-This insect breeds mostly in the wild Fig. 66-Apple Curculio; a, natural haws and wild crab apples, size; $b$ and $c$, the beetle much enlarged. and destroying these generally results in lessening the damage to

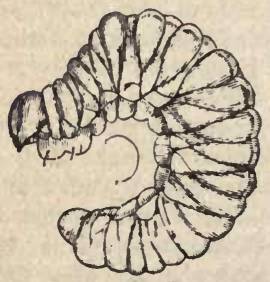

$\underline{3}$

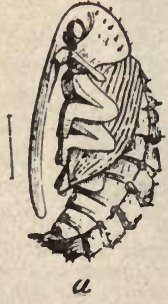

the apples in their vicinity. The windfalls should be destroyed, and pasturing hogs in the orchard is probably the easiest way to accomplish it. Sprisying the fruit with Paris green and water, as recommended for the tent caterpillar, is a satisfactory remedy and may be us=d

FIG. 6i--Apple curculio. $a$, Pupa stage; to supplement the other

the Larva worm. The hair lines indicate remedies mentioned. 
Apple Leaf Lice (Aphis mali).-The leaves of the apple are frequently attacked by lice, which by sucking the sap cause the leaves to curl up and assume a very unnatural appearance. They

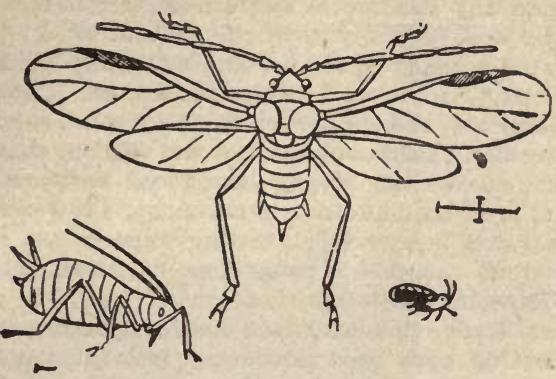

FIG. 68.-Apple Leaf Lice. showing various stages

of growth. The straight lines indicate natural size. work almost entirely on the lower side of the leaf and are most abundant on the new and tender growth. Similar lice attack the foli. age of plum, currant and other plants. The eggs of these lice are very small but shiny black in color, and may be found on the twigs of apple and other multiply with great rapidity. (Fig. 68.)

REMEDIEs. - The lice should be destroyed early in the spring before they have become numerous. The eggs hatch out about the time the buds are bursting, and as soon as the lice appear they should be sprayed with strong soapsuds, kerosene emulsion or tobacco water; the latter made by boiling one pound of rough stems or leaves in a gallon of water; will be very effective against the young lice. Kerosene emulsion is easily made, cheap and very effective. It should be sprayed on the infested trees. If the lice are allowed to get very numerous beiore spraying is commenced the work will have to be repeated several times. Kerosene emulsion made as follows:

Kerosene Emulsion.-Soft soap, one quart, or one-fourth pound of hard soap; two quarts hot water; one pint kerosene. Stir until all are permanently mixed, and then add water until the kerosene forms one-fifteenth of the whole compound. A good way to make the emulsion permanent is to pump the mixture back into the receptacle several times.

There are many other insects that occasionally injure the apple. For those that eat the leaves Paris green and water is generally the best remedy, and it may be used as strong as oue pound to one hundred gallons of water without injury to foliage, but generally one pound to one hundred and fifty gallons of water is considered about the right proportion.

Varieties.-The following list of varieties includes only the hardiest kinds and those that are generally successful in the location for which they are recommended, and that can be readily obtained from nurserymen. In very favorable locations less hardy varieties may be profitable, but it will be best for the inexperienced planter in severe climates to try only the hardiest kinds. 
In selecting varieties it should always be borne $\perp n$ mind that the experience of reliable and progressive tree growers of a neighborhood will indicate what varieties will succeed in that particular location far better than any list one is apt to receive from those not acquainted with the local peculiarities of climate and soil.

In planting do not put in many varieties, and especially avoid using many of those that are untried, or new seedlings. These latter often sell at high prices, and are generally of doubtful value and disappointing in results. Past experience would seem to show that not one in fifty of new seedling apples introduced are worth growing. If one wants to and can afford to experiment, it is a good plan to try new fruits, for it is a rery interesting pursuit, but at the same time such work can and is being done in a much more thorough way by the Experiment Station.

Russian Apples.- Under this head is includea severat nundred varieties of apples that have been introduced into this country from Russia. They vary wonderfully in form, size and quality of fruit, and in hardiness of tree. All of them have not been tried here long enough to determine their value, but enough has been learned to say that among them are many so tender, or susceptible to blight, as to be worthless for the colder portions of the United States. Others are of too poor quality, while others are too long in coming into bearing. But some of them have shown wonderful hardiness, productiveness and freedom from blight, so that they are now being more largely planted by the most intelligent apple growers of the North than any other kinds. These few Russian apples have proven to be much superior to the varieties in the old lists. In this connection it should be remembered that the apple known as Duchess of Oldenburg has been conclusively shown to be a Russian variety. Among the Russian apples are varieties adapted to every season, and the near future will undoubtedly warrant a more liberal selection of them than is here indicated.

Summer Varieties.-Tetofsky (Russian). Fruit is medium size, yellow, and of a sprightly, agreeable acid quality. Ripe early in August and quickly perishable. The tree is a close, very upright grower, and is doing well over a large portion of the Northwest. More desirab e for home garden than for market.

Yhllow Transparent (Russian).-A fine, early, yellow summer apple of extra quality, good size and productive. It is fairly hardy against climatic changes, but is very liable to blight, and should not be planted wherethis disease is prevalent. Bears young.

Late Summer and Early Autumn Varieties.-OLDENburg, OR Duchess, OR Duchess of Oldenderg (Russian). The first name is now recognized as official. The most popular late summer or early autumn apple, and the standard of hardiness as - far north as Minneapolis. Of large size and beautifully colored; rather acid. It comes into bearing very young, and is very productive. Season: August and September. Excellent for cooking in a green state or wher tipe. 
Borovinka (Russian).-Closely resembles the Oldenburg in every particular, except that it is said to be a little less acid and a better keeper.

Charlamofr (Russian). - In colom of fruit resembling the Oldenburg, but oblong in form, of good size and quality, season a little later than Oldenburg, and the tree about as hardy.

LONGFIELD (Russian).--A small, light colored, pretty desert apple, of extra good quality, that with ordinary care will keep until January. It bears young and regularly. It does best when topworked on hardy crab-stocks, and should generally be grown in that way.

RECUMBent, also called Lieby (Russian).-Without doubt the hardiest of the well-tested varieties. The tree is very spreading in habit, and is considerably hardier than the Oldenburg. A rather early and regular bearer and productive. It seldom if ever blights severely, the blighting part being confined to the new growth. The fruit is large and colored much like the Oldenburg; rather sour but excellent for cooking, and not to be despised for table use, when fully ripe. Season, late autumn and early winter as far north as Minneapolis, but may be kept until March by a little extra care.

HIBERNAL (Russian).-As it is generally grown practically the same as Recumbent.

MaC Mahon White.--A very handsome, very large, very productive light green apple of good quality. The tree is fairly productive and nearly hardy in Southern Minnesota and Northern Iowa; bighly esteemed for planting in very favorable locations. Originated in Wisconsin.

Wealthy. - A beautiful red apple of extra quality and quite hardy; it occasionally blights badly, but is wonderfully productive in good locations. It bears very young and has great recuperative powers. If killed back to the ground it seldom fails to sprout from the root, and these sprouts generally produce remunerative crops of fruit. In the bushy form thus made the trees often fruit for many years. It does best, however, when top-grafted on the branches of strong growing crabs. Season, late autumn and early winter, and it may be kept until spring by special care. Originated in Minnesota.

Supplementary List of Apples.-The following varieties have been tried to a limited extent in northern sections and are of great promise:

BReskotka (Russian).--Resembles the Yellow Transparent in fruit, though somewhat later in ripening. It has been tried only in a limited way in Minnesota, but it is quite free from blight; a full and regular bearer and much hardier in tree than the Yellow Transparent, which it will probably supplant when better known. Trees of this kind are very searce.

Thaler, or Charlottenthaler (Russian). - Much like the 
Yellow Transparent and of about the same season, but a much better tree; very productive.

Blushed Calville (Russian).-A fine summer apple resembling the Yellow Transparent in fruit, but the tree is hardier and not subject to blight.

ANisim (Russian).--An early winter apple of extra nice table quality; fruit medium in size; tree extra hardy and a strong grower. This variety has generally been sent out under the name of Good Peasant. It is not subject to blight and seldom sun-scalds.

Crab Apples.-Among these are some delicious little dessert apples, while others are only valuable for cooking. Some are very hardy and resist blight, while others are quite tender, or perhaps blight badly.

EARLY STRAWBeRRY.-Tree very hardy, of spreading growth, bearing young and heavily; fruit tender and delicious, but quickly perishable. It seldom blights severely.

WhITNEY No. 20. - Tree much hardier than the Oldenburg, and generally very productive; of very close, upright habit. Fruit of large size, handsomely striped with red, of excellent dessert quality. It seldom blights badly.

Minnesota. - Tree quite hardy, but rather a shy bearer when young. Fruit large, yellow; of fine table quality, and keeps until January. It is highly thought of by those who are growing it in Southern Minnesota and Northern Iowa. It seldom blights.

Transcendant.--Very hardy; a strong grower and very productive; it often blights severely. Fruit ripens in September, and is well known.

MARTHA. - Tree very hardy, a fine, thrifty grower and a heavy bearer. It seldom blights. Fruit large and of a rich red color; of fine quality for cooking. Ripens in September and will keep until December. Originated in Minnesota.

Virginia.-Tree very hardy and free from blight; a strong grower. It probably will stand more adverse conditions than any other apple known. Fruit as large or larger than Transcendant, and more completely covered with red. Excellent for jellies or preserves. Ripens in September and keeps for two months. Perhaps the best variety for top-grafting with the larger kinds of apples.

Tonka.-Tree very hardy, of upright growth, quite free from blight and very productive. Fruit about the size of the Trasiscendant but fiat; quite acid. Season, October. Excellent for cooking. Originated in Minnesota.

Pride of Minneapolis.--Tree very hardy, a good grower, productive and quite free from blight. Fruit of green color, medium size, quite acid. Ripens late and keeps into winter. Excellent for jellies. Were it not for its unattractive color this would be one of the most profitable crabs to grow for market as it is immensely productive. Not generally offered by nurserymen. Originated in Minnesota. 


CHAPTER XI.

THE PLUM.

A. $\mathrm{HE}$ plum is one of the most valuable of our cultivated fruits.

In point of hardiness it is surpassed by none other. Some varieties of good quality are hardy as far north as Winnipeg. It is valuable for cooking or eating uncooked. It should be more generally grown, and more attention should be paid to getting varieties that will prolong the season, which will last for at least six weeks if a proper selection is made of the kinds now offered by nurserymen at reasonable figures. There are four species of the plum which are of interest to us in this section:

(1) Prusuus domestica, is a native of Europe, and from it have come the varieties of plum commonly cultivated in the Eastern States and in California, but varieties of it generally cultivated in these sections are not hardy here. There are, however, a number of varieties of this species which have been introduced from Russia and promise to be of some value here.

(2) Prunus Americana, is the plum found in our woods in its wild state. It is far superior to the original form of the preceding species, and it is very probable that under cultivation many very desirable varieties will be developed, which will be hardy enough for this section. Already selections have been made from it by our nurserymen which are vastly superior to the kinds ordinarlly found in the woods. These vary much in size, form, quality and color. Some are very nice dessert fruit, some have free-stones, while generaily they have cling-stones. This is the most promising species for this section.

There are two forms of this. One is rather a small tree with black twigs and close head, having small, very astringent purplish fruit. The other is more open in its habit, makes a larger tree, and has ratber large fruit colored with red and yellow. It is to this latter form that we must look for the best varieties for cultivation.

The two other species of interest to us are (3) Prunus hortulana and (4) Prunus angustifolia. These species are seldom found north of Central Iowa. Many of them are not hardy enough for Northern Iowa, but some varieties of it are hardy as far north as St. 
Paul, although, as a rule, they do not fruit well so far north. All these species readily hybridize together.

Propagation.-The plum does not come true from seed, although there are some varieties which neariy reproduce themselves in this way. However, the seed is sown in order to produce new varieties, and the stocks into which the named kinds are budded or grafted. If the seed is allowed to get very dry before planting it will lie in the ground one year before it will start; but if it is buried at once after separating it from the flesh it will come up the following spring. Seedlings bear in from three to five years from seed. They are generally large enough to graft upon when one year old, and if given plenty of room, in rich soil, are large enough to be budded the first year from seed.

Nurserymen generally offer plants that are grafted or budded. It matters not by which method they are grown, as long as the root on which they are worked is hardy. For this purpose native seedlings are most desirable and should be used when possible, but Angustifolia and Hortulana stocks do very well if planted pretty deep. A European form of the plum called Myrobolan is frequently used by nurserymen for stocks, but its use in this section is to be discouraged, as it does not stand well here. If plums are to be grafted the work should be done very early in the spring, even before the frost is out of the ground.

Thrifty Suckers make very desirable trees when grown for a year or two in the nursery. They should be taken up with a short piece of the main root from which they grew (Fig. 69). If simply pulled up they are often of little value. If the smailer roots around the trees are cut while they are dormant, as in the early fall or eariy spring, they will readily sprout. Most varieties of the plum will grow from pieces of the root made into cuttings about six inches long in the fall of the year and planted out in spring. Such cuttings should be buried in the ground until planted out. One advantage of having trees that are grown from suckers or cuttings is that they are on their own roots and consequently any suckers from them will be true to name, while suckers from grafted or budded trees are of little if any value.

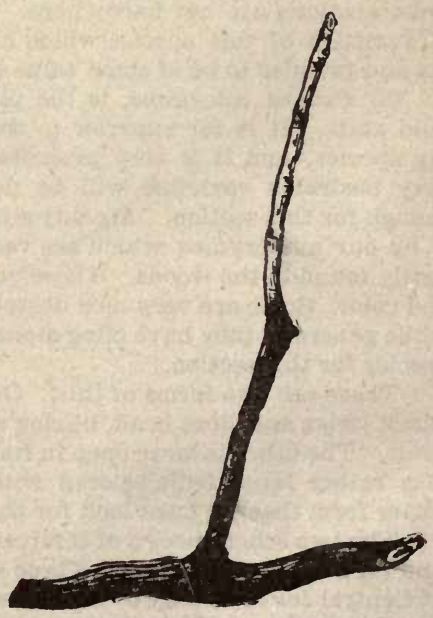

FIG. 69.-Plum sprout properly taken up with a piece of the root from which it grew. 
Profits of Cultivation.-In good locations this fruit may be grown at considerable profit. Occasionally the numerous wiid plums somewhat affect the demand for the cultivated kinds, but wild plums are growing scarcer with each succeeding year, and the consumers already begin to discriminate between the wild and the cultivated varieties, and are willing to pay more for the latter. No one should be contented to plant with the common wild kinds when varieties so very much better can be obtained at a moderate price.

Location.-The best location for the plum is on high land, sloping to the north and having a retentive soil, and protected from the east winds, as the storms from this direction are most injurious at blooming time. It will, however, grow and fruit abundantly in almost any situation. It will stand much neglect, but responds quickly to good cultivation, which it must have to be profitable.

Planting.-The trees may be set out either in the fall or spring of the year, but spring setting is most desirable. If planted in autumn the work should be done by the middle of October, and the soil watered if dry. The best trees are those which are two years from the graft or bud and grown on native seedling stocks. Thrifty suckers also make good plants if well rooted. The trees should be planted about ten feet apart in rows, leaving sufficient distance between them to allow for a free circulation of air. It is preferable to plant in rows running north and south, and they should not be nearer together than twenty-four feet. The same general directions given for planting the apple will apply here.

Cultivation.-Land around the trees should be thoroughly cultivated for the first three years. If thorough cultivation cannot be given the trees should be heavily mulched, and this is by far the best treatment for them when they become old.

Renewing Old Trees.-Plum trees are inclined to over-bear and to exhaust themselves, after which they often die out or the fruit becomes very small and of poor quality. On that account manuring should be resorted to when the trees fail to make a satisfactory growth. Quite frequently as the trees get old the fruiting branches become very long and bare with all the fruit near their extremities. In such shape they are liable to split down in the crotches. When trees get into this condition the longer branches should be shortened back (as shown in Fig. 70), and some care taken in removing or shortening the suckers that will start so as to make a good top to the tree. Where a crotch is found cracked it is a good plan to hold it in place, driving a wire nail through it far enough so that its end can be turned over. This will often affect a permanent cure.

Pruning.-The notes on time and manner of pruning given in the chapter on the apple will apply here. Plum trees should be pruned so as to allow the branches to start out about two feet from the ground. The trunks of plum trees do not sun-scald readily, but if long stems are exposed the growth on the south side is 
weakest and the trees are very liable to become onesided. Exposed trunks are also liable tn a fatal gumming disease.

Mixing Varieties.-Some varieties of the plum have flowers which seem to be impotent to their own pollen, that is they are not fruitful when growing away from other varieties of the plum. Then again other varieties, while seemingly potent to their own pollen, fruit much more abundantly if they are pollenized with some other variety. On this account it is always desirable to plant more than one variety of the plum, and even to mix the vari-

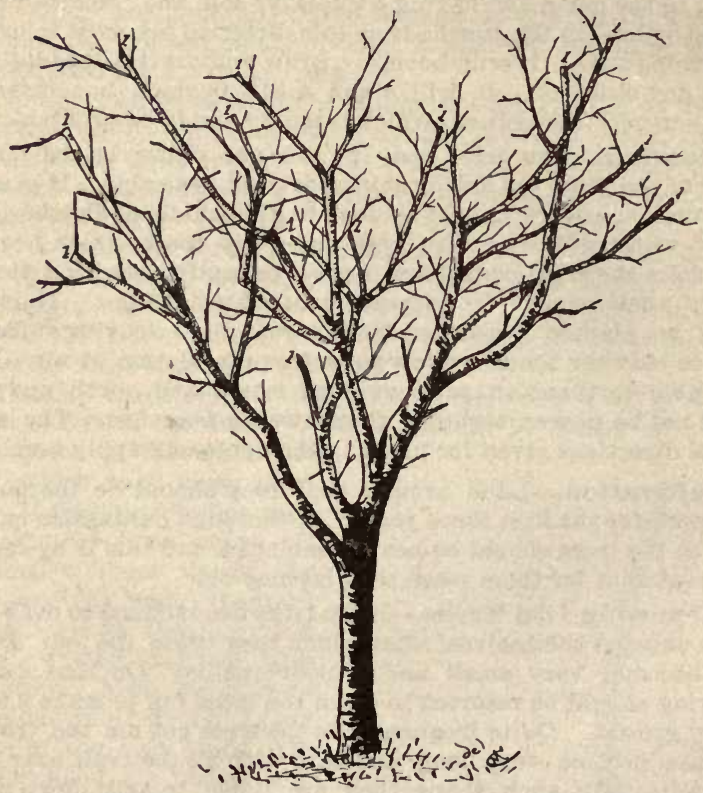

Fig. 70.-Renewing an old plum tree, The long branches have been shortened in to encourage compact form. The figures 1 indicate where pruning has been done.

eties together by planting them alternately in the rows. Some varieties which are entirely unfruitful when growing alone are very productive when grown by the side of some other kind having strong pollen.

Marketing.-The rule of never sending fruit to market in rough, unsightly or unusual packages, holds well here. Plums should never be marketed in rough baskets, tubs or boxes, as is often practiced, but in some of the popular commercial fruit packages, which can now be ootained at very low prices. 
Varieties.-The varieties mentioned below ripen about in the order in which they are described. They are all good fruits and desirable. By selecting three or four kinds the season of fruiting may be made a very long one. There are a number of other varietics that are very good, and several untried ones said to be better than any mentioned, but those referred to have been tried for a considerable time.

Cheney. - A very early plum of largest size and excellent quality. Tree, a very strong grower, hardy and productive. This variety flowers very early, and on this account is more liable to have its blossoms injured by late frosts than some others.

FOREST GARDEN.-An early plum of high flavor and fair size, but its skin is rather thick and astringent. Tree a strong grower and fruitful.

WoLf.-A free-stone plum of large size and excellent quality; pit very small. Tree a good grower, hardy and fruitful.

RoLLINGSTONE.-A large plum of excellent quality. Tree vigorous, hardy, with rery crooked branches. Season, second early. In scme location a heavy bearer. Fig. 71.-Section through

WEAVER. - A valuable late large plum Forest Garden plum. of good quality, having its pit free from the flesh. Skin not astringent. Tree a strong grower, very hardy and fruitful.

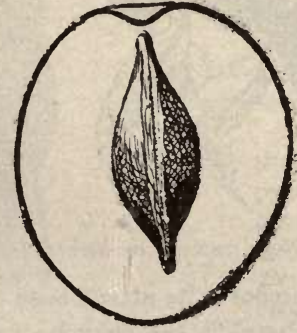

FIG. 72.-section through Weaver plum.

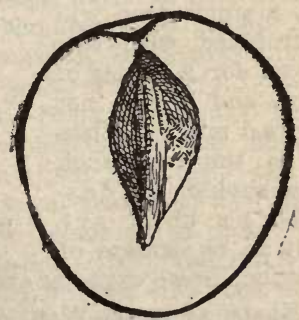

FIG. 73.-Section through De Soto plum.

DE SoTO.-A late variety of medium size and good quality. Tree a vigorous, good grower. Thought by many to be the most reliable of our native plums.

WYANT. - A new variety which is reported on highest authority as being of the best quality. It has been growing at the Minnesota Experiment Station for two years and appears to be hardy. 
Diseases of the Plum.-Plom Pockets.-This is a name given to certain peculiar bollow deformities which occasionally take the place of the plums (see Fig. 74). They consist merely of a thin shell with no evidence whatever of seed. Some seasons this disease is very abundant, and then for a number of years it may scarce appear at all. It is due to the presence of a parasitic fungus ( $T a p h$ rina pruni) which attacks the young fruit, and by growing within it causes the peculiar development which finally results in the formation of the so-called pocket. The only course of treatment which can be recommended is that of removing and destroying the pockets before they reach maturity. It will sometimes be found that a single tree will be troubled with this fungus for a series of years, and it will not spread much. When this is the case such trees should be destroyed, as they are likely to be centers of

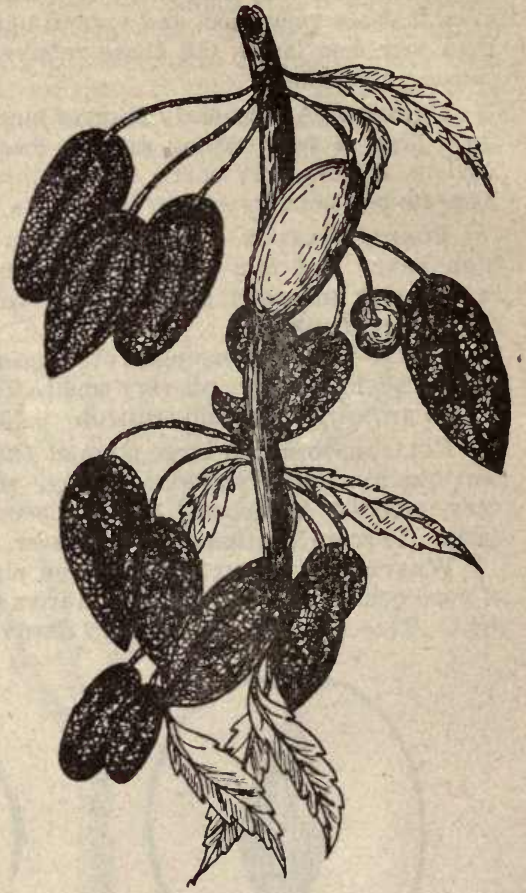

FIG. 74.-Plum pockets, or diseased plums. infection. Some varieties are more subject to its attack than others.

BLACK-KNOT, OR WART OF THE PLUM, is the common name of the fungus disease of this tree which manifests itself by knot-like or wart-like growths appearing on the smaller limbs as well as on the larger branches, and sometimes even on the trunk (see Fig. 75). In sections of the country where Prunus domestica is grown this is one of the most serious obstacles to successful cultivation of the plum. Our native plums are not often destroyed by it, but it sometimes causes serious injury to them. This knot-like growth is spongy and of a black color. Upon examining it with a microscope it is found that the surface has many little cavities which contain the spores by which the disease spreads. It is probable that the 
spores escape from the knots during the late winter or early spring months.

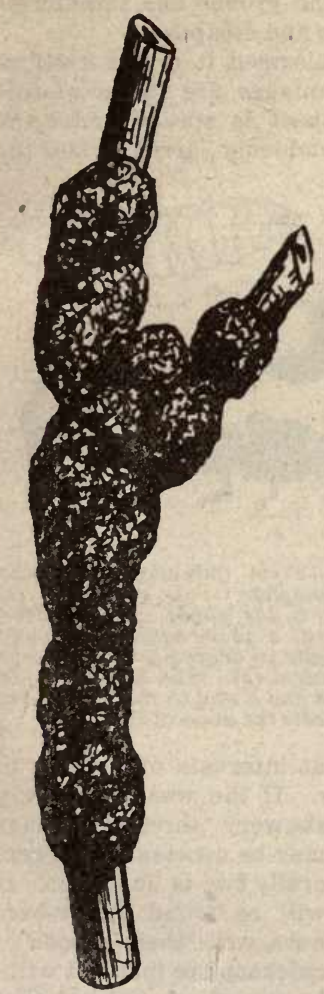

FIG. 75.-Black knot, or wart on plum wood.

Remedy.-Upon their first appearance these swellings should be removed and burned, if they are on the smaller branches where it is practicable to cut them off; if on the trunk or larger branches where they cannot be cut out they should be painted with a paste made of yellow ochre and linseed oil, using care to keep the oil away from the healthy bark; where trees are very badly infested they should be removed entirely. This same disease also grows in the wild black and choke cherries, and if abundant on them their removal will make the extermination of the disease more easy.

Other Diseases.-There are several other fungus diseases which occasionally injure the plum. One of them (Monilia fructigena) causes the fruit to rot, while another produces round, dry, scabby spots on the skin. Probably the best treatment where these are abundant is to spray the fruit with Bordeaux mixture as soon as it is well formed, and again when about half grown. For recipe for making Bordeaux mixture see chapter on the strawberry.

Insects.-PlUM CuRCUlio.-This is the insect which causes the plums to prematurely ripen and drop to the ground. It is not nearly so destructive to our native plums as to those of the Prunus domestica tribe. The latter are often so badly infested that none of the fruit comes to full maturity. While our native plums are stung just as much by the curculio as the others, but few of the eggs of the curculio develop into the grub. This insect is a small, rough, greyish or blackish beetle, about one-fifth of an inch long with a black, shining lump on the middle of each wing, and behind this a more or less distinct band of a dull yellow color, with some whitish marks about the middle (see Fig. 76). The snout is rather short. The female lays her eggs in the young green fruit shortly after it is formed. After laying the egg she cuts a circle round it to prevent the part in which the egg is laid from growing (see Fig. 77). The egg hatches in a few days and the larva works around the outside 
of the stone. This causes the fruit to become diseased and it falls prematurely to the ground. Within the plum the growth of the larva is completed. It then goes into the ground and transforms to the beetle and soon goes to the surface and escapes.

Remedy. - When the curculio gets alarmed it draws itself together and falls to the ground. Advantages are taken of this peculiarity to catch and destroy it. A sheet is spread under the trees and the tree and its branches are suddenly jarred, when the beetles, which fall on the shect, may be gathered up and destroyed. As it is important to catch as many beetles as possible before any mischief has been done, jarring should begin while the tree is in blossom, and be continued daily morning and evening, if the insects are abundant, for three or four weeks, or until they become very scarce.

Another remedy which is less laborious and has been found very effectual is to spray the plums as soon as the fruit is formed with Paris green in the proportion of one pound to two hundred gallons

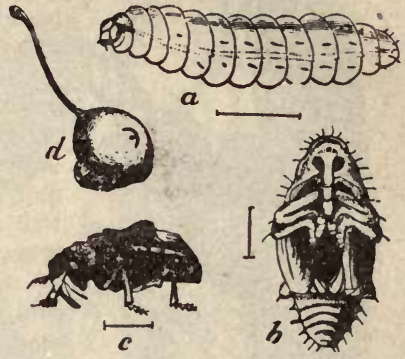

FIG. 76.-Plum Curculio (Conotrachelus nenuphar.) $a$, represents the worm; $b$, the pupa; $c$, the perfect beetle; $d$. a plum showing the puncture macle in deposing the egg, uni the crescent cut. The hair-lines just below a and $c$, and to the left side of $b$, indicate the nat ural size. of water, and repeating the application at intervals of a week or ten days until the curculios disappear. If the weather is very
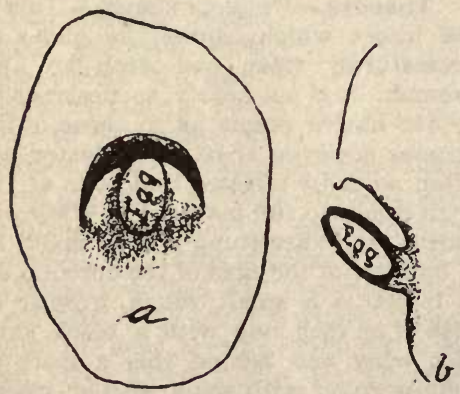
showery three sprayings may be necessary, but generally two is sufticient. It will be found that where hers with their broods of chickens are inclosed within the plum orchard that they will devour a large number of the larva of the curculio. If hogs are kept in the same inclosure as the plum trees they will pick up the fallen fruit and so destroy a great

FIG. 77. - a, Part of plum showing egg-punc- many of the larva. ture, and location of egg, from above; $b$, section through egg-puncture, showing egg.

Plum Godger. - The plum gouger is a snoutbeetle somewhat resembling the curculio, but readily distinguished from it by a little careful examination. it is about five-sixteenth 


of an inch long. The head and wing cases are brown with a leaden grey tinge, the latter with whitish and black spots scattered irregulariy over their surface. It appears in the spring about the same time as the curculio, and it causes the plums to drop in much the same way as the curculio, but instead of working around the stone it eats through the soft shell and lives within the stone, where it undergoes its changes and emerges a perfect beetle. Both sexes of the plum gouger bore cylindrical holes in the fruit or food. These cause the fruit to become knotty and worthless, but it does not prevent their remaining on the tree until maturity. This insect does not cut a flat or half circle around the hole in which the egg is placed, as is characteristic of the curculio. The remedies recommended for the curculio are the best for preventing the work of this insect.

ApHIS, or LEAF LICE.-These are often abundant upon the native plums. They live upon the under side of the leaves; are generally not observed until they are very abundant, and increase with great rapidity. They resemble very much the apple aphis before described, and the same remedies will be applicable here. It is of the utmost importance that treatment be commenced early. As a rule, if they are abundant during the summer their presence could easily have been detected early in the spring when they were not numerous, and when it would have been but a small matter to destroy them.

There are a number of other insects that injure the plum, but they have been referred to under the head of insects injurious to the apple. 
CHAPTER XII.

THE CHERRY.

1. $1 \mathrm{HE}$ species from which the commonly cultivated cherry is derived was probably the Prunus cerasus, of Europe and Asia. It is not indigenous to this country. There are two distinct groups of this fruit. The first comprises those kinds of a strong, upward, straight growth, pyramidal form, and sweet or bitter but not sour fruit. The second group has sour fruit, and either a spreading or upright habit, and the young branches are crooked. This group is divided into two classes, which were formeriy termed Morrellos and Dukes, although the reason for this distinction has been largely done away with by their becoming intermingled by crossing. To this latter group belong all the varieties that can be successfully grown north of what might be called the "peach beit", and therefore those that are of interest to growers in such latitude.

Historical.-Until the importation of East European varieties of cherries there was little encouragement for any one to plant this fruit in the colder sections of the West. The hardiest West European varieties, such as the Early Richmond and English Morello, are not reliable in the North, though after lasting well for a few years. The East European kinds, which are often referred to as the Russian cherries, while as yet tried for but a short time, give promise of being an important addition to the list of cultivated fruits for all northern regions. At present they can be bought of but few nurserymen, but as they are easy to propagate it will not be long before they can be readily and cheaply obtained.

Soil and Loeation.--The best soil for the cherry is one that is drier than is desirable for most other fruits; a sandy or gia velly loam, with porous subsoil, is best. In wet places. or on watersoaked subsoils. it soon perishes. The best locations are on high land, but a rise of even a few feet above the surrounding country is of great advantage.

Propagation.-The cherry does not come true from seed, though seedlings are often of very good quality. Seedlings are 104 
generally used as stocks on which to work the named varieties. The pits (seed) should be managed as recommended for plum pits. Named varieties of the cherry are propagated by budding, grafting, and from suckers. Budding and grafting are generally done on either of two kinds of seedling stocks, called Mazzard and Mahaleb, which are imported from France. These are not as hardy as is desired, and in fact are too tender to be left without protection in winter, though they may last well if protected by deep planting. Seedling bird cherry (Prunus Pennsylvanica) is the best for stock purposes. Recent experiments with the sand cherry (Prunns Pumila) seems to indicate that it may be useful for this purpose by budding, but not by root-grafting.

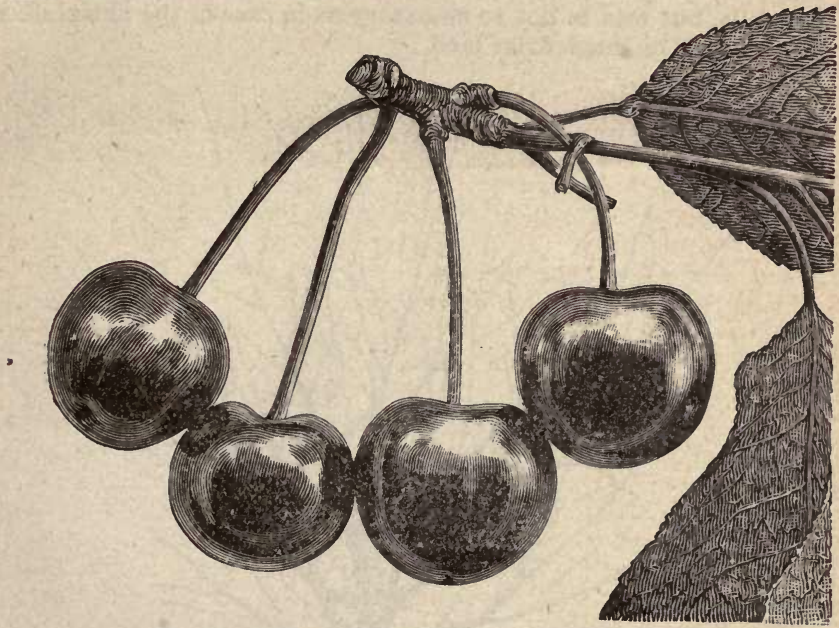

FiG. 78.-Showing fruit of Early Morello Cherry.

Suckers.-Most of the cultivated kinds that are valuable for northern sections sucker readily if they are cut back to the surface of the ground, but, of course, where such practice is attempted the trees must be on their own roots, or the suckers will not be like them. This method of propagation is seldom practiced in tiis country, but may readily be followed wherever there are old trees on their own roots. It is the method generally preferred in Russia, and will undoubtedly prove best adapted for severe locations here.

Cuttings. - A few of the various cherries may be grown from cuttings, but this method is very uncertain and requires much careful management. On this account it is seldom practiced.

Planting. - The varieties of cherries that are hardy in this section do not make large trees, but are c'ite $d$ warf and bushy in habit, and on this account they may be planted quite close to- 
gether. It is generally best to plant about eight feet apart, in rows fifteen feet apart. Most of the plants sent out are budded or grafted on tender roots, as they are most easily obtained. These may easily be winter-killed if exposed and cause the death of a tree which might otherwise be perfectly hardy. On this account the roots should be planted from four to six inches deeper than they grew in the nursery, to afford them the protection of the soil. Besides this, when pianted deep the scion sends out roots, and when a tree is thus on its own roots its powers of resisting adverse conditions is greatest.

Cultivation.-The cultivation suggested for the plum applies here. It is important also to mulch the trees when on exceedingly dry soils, but this is not so necessary as in case of the pium, since they do well on much drier land.

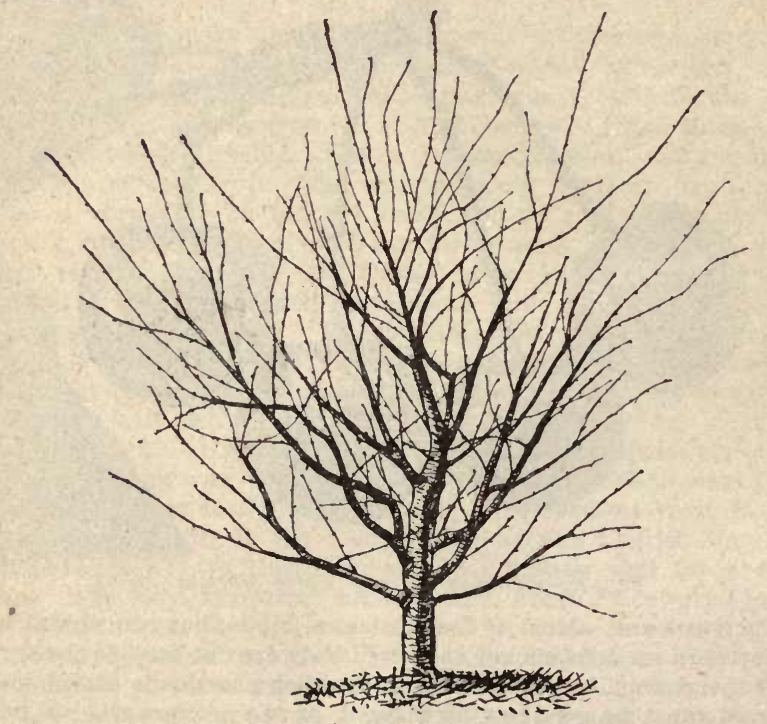

FIG. 79.-Cherry tree of good form.

Pruning.-The cherry needs only enough pruning to keep the tree in shape, and but very little is required to accomplish that. In Russia it is grown in bush form, and when it becomes too old to bear profitably the older parts are cut away and new sprouts take their places. The important point to remember in connection with this, as well as all stone fruits, is that they should be trained to branch low.

Insects and Diseases.-The insects and diseases which affect the cherry are about the same as those that injure the plum, 
and the same remedies are applicable here. But the cherry may be injured by several insects that injure the apple, and they will be found referred to in the chapter on that fruit.

Varieties.-The varieties which have proven most hardy thus far are Early Morello (23 Orel), Sklanka, Bessarabian (No. 62), Cuse d' Ostheim; but there are several others that are standing well and may prove valuable. 


\section{CHAPTER XIII.}

\section{BUDDING.}

T) $\mathrm{N}$ its broad sense the term grafting, or graftage, inciudes all there is of budding, which is simply grafting while the tree is growing. But as generally used budding applies to the process by which a bud of the season is removed from its parent plant and induced to unite with and grow upon some other plant congenial to it. In the northern states it is commonly practiced to propagate plums and other stone fruits, and apples and pears, all of which are readily increased in this way. The varieties of some ornamental trees and plants may be propagated by budding, as for instance some varieties of elm, maple, poplar and birch. Most trees that graft readily will bud as readily, whlle others that are very difficult to graft will bud very easily. Budding is rather a simpler operation than grafting, and easier for the beginner to perform successfully.

The word "stock" is used to designate the plant into which the bud is inserted, and for success it must be of the same or some nearly allied species. Stocks are generally grown from seed and the buds are inserted in them before they are five years old, and as near the ground as may be. But budding may be done very successfully on any growing branch or stem where the bark is not too hard and stiff to bend easily. It is often used to change the bearing quallties of fruit trees of small or medium size.

Bud-stick is the name given to the shoots from which the buds are taken. It is also referred to as the scion, but the scion proper is the piece which is inserted in the stock. In Fig. 80 is shown at $D^{\prime}$ a bud-stick prepared for use by cutting off all but about one-half inch of the stock of the leaf, which part is left for a handle.

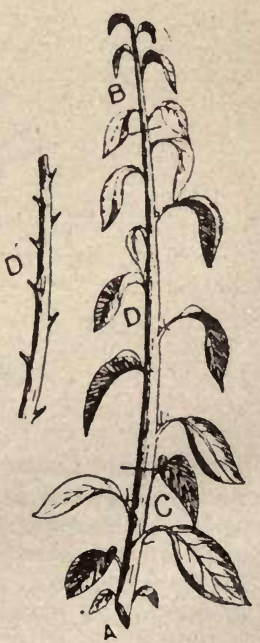

FIG. 80.-Shoving Bud Sticks. 
Time for Budding.-In a general way, budding may be done at any time when the bark will peel, providing the buds are sufficiently matured on the new growth of the season. The proper time will be influenced by the kind of stock used, the season, and sometimes by attacks of insects and diseases. For instance, the native plum is generally budded to best advantage about the tenth of August, but should the stocks be attacked by some insect or disease that seriously injures the foliage in the latter part of July the growth of the stocks will soon be checked, and the work must be performed at once or not at all. A period of severe drouth may check growth, and in a similar way make early budding necessary. If the stocks are growing very fast it is often best to delay the operation until the wood has become somewhat hardened, or else its rapid growth may cover up the inserted bud. If considerable pruning of the stocks is necessary to make a place for the bud it should be done at least two weeks before budding is commenced, for the heavy pruning of any plant when it is in active growth results in a serious check to the growth, and if done just when the buds are inserted it may prevent the success of the operation. The ordinary season for budding in the northern states is from the middle of July to the first of September, and the earliness or lateness at which a variety is most successfully budded depends on the condition of growth. The stocks that stop growing early in the season are budded early, and those that grow until autumn are budded late. The conditions for success are:

(1) The stock and scion must be perfectly healthy and free from insects. If either of them are weak or sickly unsatisfactory results may be expected. To this end everything necessary should be done to keep off insects and diseases.

(2) The buds should be well developed in the axils of the leaves on the young shoots from which the buds are to be taken. It seldom happens that they are in this condition until the bud at the end is formed, but sometimes the buds in the center of the twigs will be large enough to grow, while those at the base and at the extreme tip are still quite small. In Fig. 80 the buds shown between $B$ and $C$ are supposed to be mature enough for budding, while those at the base are too small, and those at the tip, beyond the cross-line, are too soft. If the buds are thought to be too immature they may readily be developed by pinching off the tips of the twigs. In ten or twelve days after such pinching, of even a very soft shoot, its buds will be fit for working.

(3) The bark must separate easily from the wood on the stocks to be budded. This will take place only when they are growing rapidly.

(4) A sharp, thin knife is absolutely necessary.

(5) The work must be done rapidly, and the buds firmly and evenly tied into place. No wax is needed. 
Necessary Implements.-A common shoe-knife with the corners rounded off, as shown in Fig. 81, makes a very cheap and yet a most excellent budding knife. There are many specially

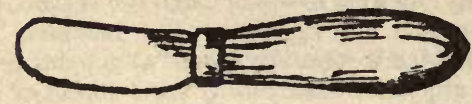

FIG. 81.-Budding Knife. designed forms of knives for this purpose, and most of them have an ivory point or blade in the base of the handle for lifting the bark, but the rounded corner of the back of the shoeknife is just as good as the best ivory blade for raising the bark, and a shoe-knife costs not one-fourth as much as an ordinary budding knife, and generaily holds an edge better.

Besides a shoe-knife, tying material is necessary. For this purpose basswood bark is perhaps the best, since it is but little affected by moisture, and if put on wet remains tight and close. But corn husks, cotton warp or woolen yarn answcrs very? well, and a tying material called rhaphe is largely used for this purpose, but it should be put on dry, while basswood bark should be used wet.

BAsSWOOd TYING MATERIAL is prepared by soaking sections of the bark in water until the inner layers separate easily. The bark peels from the trees readily in June and July, and it requires about three weeks of soaking in stagnant water to get the fiber into the right condition. After the layers readily separate the bark should be stripped into pieces about one-fourth of an inch wide. If hard and stiff it may be softened by rubbing or pounding it.

The Process of Budding will be found illustrated in Figures $82,83,84,85$ and 86 , which show the successive stages in shield budding, which is the form generally used in this country. When everything is ready for the work prepare a lot of bud-sticks, as shown in Fig. 80, by cutting off all but about one-half inch of the leaf stalks. These sticks should be carefully protected from wilting, and it is customary to carry them in the field wrapped up in moist cloth or oiled paper. If it is necessary to store them after they are cut they should be kept in a cool, moist place in moss or sawdust, or cloths, but not in water. They are of ten kept for a week before using, but should be used as soon as may be after they are cut.

To Insert the Bud a smooth place should be selected (on small stocks this should be about two inches from the ground) and on the north side if practicable, since buds are less liable to be injured by freezing on that side than on any other. A cross-cut should be made at this point, and from it a cut about $11 / 2$ inches long, as shown in Fig. 82; at the same time the bark should be raised, as shown in Fig. 85. A bud-stick is then taken and a bud cut off with the bark and a thin piece of wood (Fig. 861/2) extending about onenalf inch above and below the bud, as shown in Fig. 83. The lower 




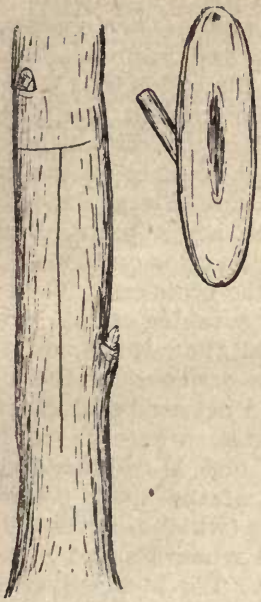

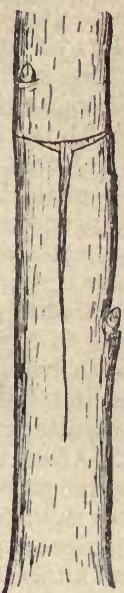

Fig. 84 .

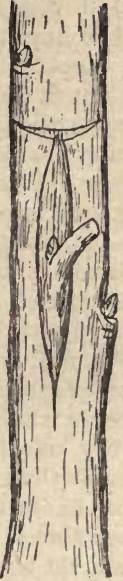

FIG. 85.

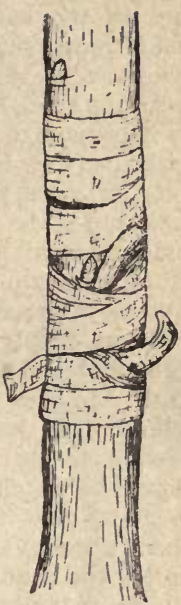

Fig. 86.

FIG 82 - The way the cuts are made in the stock. Fig. 83. -The bud when cut off; sfe finm under sille. FIG. 84 - The bark raised for the insertion of the bud. FIG. 85.-The bud inserted. FIG. 86.-The bud tied in place.

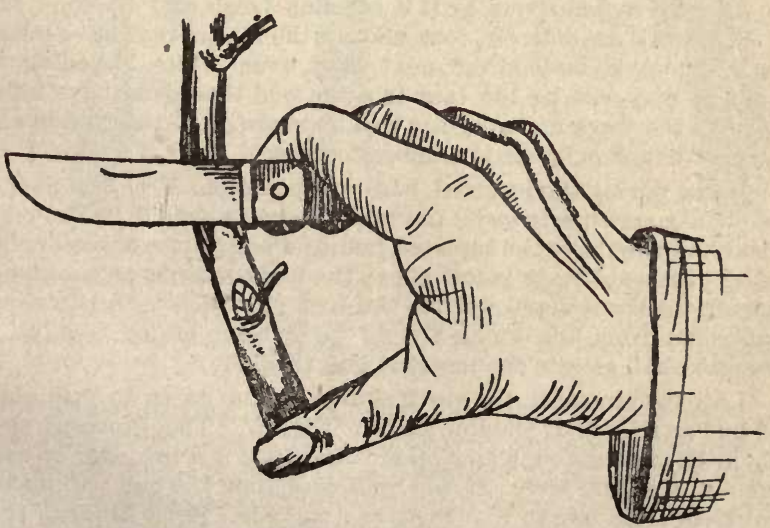

FIG $861 / 2-$ Showing the way in which the bud is cut off and its relative size. The 3:nshaded pant around the bud represents the puece of bark taken off with the bied. 
point of the bud (by which is meant the bark and wood cut off as well as the bud) is now inserted under the bark at the cross-cut, and is gently pushed down by the leaf stock and knife blade. If the bark of the stock will not raise when the bud is thus pushed down the stock is not in the best condition for budding, and it will be necessary to raise the bark with the back of the knife blade, or with the ivory blade previously referred to, in order to let the bud come into its place. The sides of the bud should come under the bark, but if the wound is not large enough to admit quite all the bud, any small part that may project above the cross-cut should be cut off by again drawing the knife through the cross-cut. The bud must now be securely and firmly tied in place, taking care to draw it down evenly and firmly and to cover all the wounds with the tying material (Fig. 86), but not to draw the string over the bud itself. In less severe sections the ties do not need such careful attention as here in the northwestern states, where it is important to tie very carefully. After the bud is tied the bands should be watched so that when the growth of the stock becomes so great that the bands are too tight for it (which is generally in about a week) they should be loosened, and when the bud is well united the band should be cut off altogether. The buds will generally unite in about two weeks, but sometimes they will require a longer time, and it is often desirable to leave the ties on for some little time after this period. It is a bad practice to neglect the bands and allow them to severely cut the stork.

The inserted buds should not start at all until the following spring. If they start into growth the season they are inserted they are almost certain to be killed the following winter. If the bark of the inserted bud shrivels, or if it remains fresh and the bud falls off the work is entirely lost, though the stocks that have missed one year may be budded the next, and even while loosening the bands it may not be too late to again bud those that have failed. To make the work more certain two buds are often inserted in each stock, although only one is allowed to grow.

In the spring the inserted bud will resemble Fig. 88 . Just as the buds commence to swell the budded stocks should be cut off at least one inch above the inserted bud, and sometimes seven or eight inches of the old stork is left above the bud to serve as a stake to support the shoot starting from the bud (Flg. 87). All the shoots that come from the stock should be rubbed off so that all its strength shall go into the inserted bud (Fig. 87).

Late in the season the stock should be cut down to just above the bud as shown by the line at $B$ in Fig. 87. The growing shoot should be trained to a single stem if its stock is a low one, so as to make a straight tree. If the root is strong the bud will make a growth of from two to four feet the first year. Some kinds of trees readily take on an upright form, while others naturally grow very crooked and need speciål care to induce them to grow straight. 
On the approach of winter it is a good plan to draw the earth up against the buds as a protection, but this cannot be done when the buds are more than two or three inches from the ground. If the buds are too high up to allow of this earthing up from the ground, especially in the case of somewhat tender kinds, some growers put a very thin covering of grafting wax around the bud, taking care not to cover the tip of the bud more than a very little. This covering is a protection against ice forming behind the bud and from sudden freezing and thawing in winter. However, with our hardy trees this precaution is not necessary.

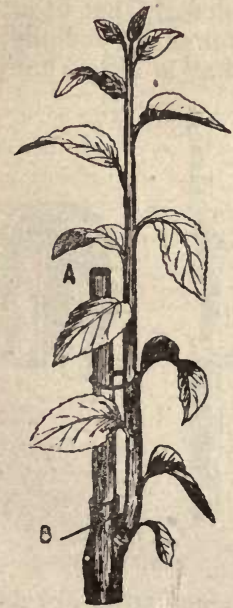

FIG. 87.

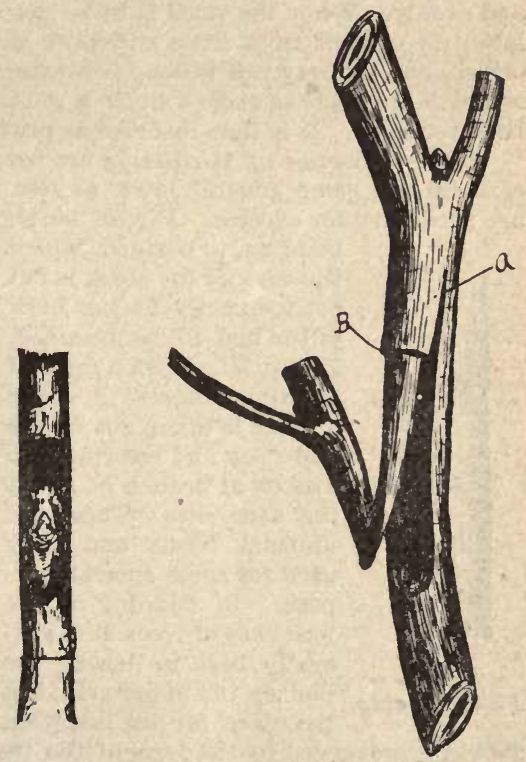

FIG. 88.

FIG. 89.

Fig. 87. - The shoot starting from the bud tied to a portion of the stock, $B-A$. The line $B$ indicates where the s'ock should be cut off late in the season. FiG. 88.-A plum buil in the spring of 1893 before growth com mericed. FIG. 89.-The way in which a bud should be cut if the bark is to be taken out. A form not used much in this country.

June-Budding.-Many eastern nurserymen offer what they call June-budded trees, at low prices. They are small trees that can be easily sent, by mail, and are made by an operation similar to common budding, as described herewith, except that the work is done in June, and the inserted buds are forced into growth as soon as they adhere to the stock by cutting off the latter. They make only a small growth the season they are budded. The buds for this 
purpose may be hastened in maturing by pinching in the ends of the shoots to be used for bud-sticks. For ordinary purposes nothing is gained by budding in June, for a plant budded in August will make as large, if not a larger, growth by the end of the following year than a June-budded tree of the same age will make in its two years of growth, and will make a straighter tree.

The bark is removed from the bud after it is cut off by some budders, but in general practice in this country it is left on. However, care should be used not to cut the bud very thick, or the large amount of wood in it will prevent its binding into place smoothly and evenly. When the wood is to be removed from the bud the latter is cut off in a little different way from the method described, and the way this is done is illustrated by Fig. 89 . The cuts $A$ and $B$ are made in order and by a dexterous twist the bud and bark removed. It is then inserted as previously described.

Other Forms of Budding are used occasionally, but in all of them the same general laws, as laid down for shield budding, are necessary for success. Figure 90 shows what is called flute budding, to perform which

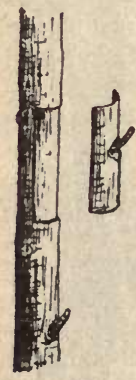

FIG. 90.

Flute Budding the bark of the stock is cut out to exactly fit the bark of the bud to be inserted. Figure 91 shows a form of budding wherein a circle of bark is taken out of the bud-stick and inserted into a stock or branch of about the same size. These are unusual forms and only used for some special purpose. In budding on the branches of trees it is generally best to insert the bud on the upper side, but the place for its insertion

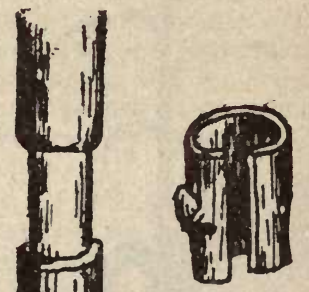

should be governed by the form of the tree. Budded trees are no better than grafted trees, but they may be as good, or perhaps worse, according to the way in whlch the work is done. If the buds and stocks are perfectly hardy, as for instance when our native plum seedlings are budded with similar kinds of improved quality, as with the DeSoto plum, then the tree resulting is as good as if root-grafted. But if the hardy kinds of ap-

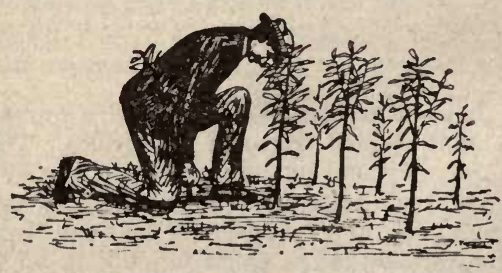

F1G. 9:.-At work inserfing buds near the groused on small stocks. 
ple are budded on ordinary seedling. which are mostly not hardy, then there is a part of the tender seedling whlch is above ground and is liable to be killed out by cold. In this case the resulting tree would be much improved if the seedling root had been grafted below ground instead of being budded above, so as to have the benefit of the protection the ground afforded. On the other hand where hardy trees are budded on the branches to change the bearing the work is just as sure as if grafted. It is foolish, then, to pay more money for a budded than a grafted tree. 


\section{CHAPTER XIV.}

\section{GRAFTING.}

(6)

RAFTING is distinguished from budding by being performed at a season of the year, generally in the spring, when vegetation is dormant-at least when the plant operated upon is not in full leaf; but there are many exceptions to such a definition, and it might be better to include the two subjects of budding and grafting under the general head of graftage, as they are closely related. It is the object of this chapter to discuss some of the methods of grafting as used in the propagation of fruits.

Limits of Grafting. - It is quite common to hear very surprising stories about grafting. Quite lately a prominent grape grower referred to his efforts to graft the red currant on the red maple tree. Even Pliny says: "Some apples are so red that they resemble blood, which is caused by their being grafted on a mulberry stock." But grafting or budding is never successful unless the graft and stock are nearly allied, and the closer the relationship between them the more certain the success. Snidley says: "Varieties of the same species unite most freely; then species of the same genus, then genera of the same natural order, beyond which the power does not extend." For instance: pears work freely on pears; very well on quinces and mountain ash; less successfully on apples or thorns, and not at all upon plums and cherries; while the lilac will take on the ash, because of the near relationship between the two. But there are many exceptions to any rule that could be laid down concerning this matter. Some plants are increased most readily by budding, while others graft more easily than they are budded. The stone fruits are very easily budded, but grafting them is a much more uncertain operation.

Stock is the term used to indicate the plant grafted upon, whether large or small.

Scion is the term used to express the part inserted, of whatever size or form it may consist. These should be of the new, well ripened growth of the season. If scions are to be used in the spring they should always be cut late in the fall, as they are liable to be injured by the winter. However, spring cut scions may 
often be used successfully, but it is not safe to trust to them, especially if when cut open the heart wood appears dark colored. Scions should not be cut when frozen. They should be stored in moist sawdust or sand in a cold cellar, or buried in the ground outdoors during winter. Cherry scions are most safely carried througis the winter when packed in moist leaves. If packed in sand or sawdust they sometimes become water-soaked.

The Principles which under ie grafting are the same as in budding, i. e., the scion and stock must be closely related; the work must be done in such a manner that the inside bark of both scion and stock come closely in contact; and at a season of the year, and under such circumstances, that they may unite at once, or as soon as growth starts. The success of the operation largely depends (1) on having the stock and scion perfectly healthy; (2) in selecting the proper season, which varies somewhat with different plants; (3) in getting a perfect union of the inner barks of scion and stock at least on one side; (4) in making all the cuts with a sharp knife, that the parts in contact may have a smooth surface; (5) in doing the work rapidly, so that the surface may not be exposed.

Grafting Wax is generally used for covering the wounds made in grafting. A gord grafting wax is one that will not become too soft in summer, so as to melt and run down the stock, or so hard in winter as to crack and split off. A very reliable grafting wax is made by melting together: resin four (4) parts, by weight; beeswax, two (2) parts; tallow, one (1) part. When well melted pour into a pail of cold water, grease the hands slightly and pull the wax until it is about the color of pulled molasses candy. Make into balls and store for use. This wax should be warmed when applied. If it is too hard more tallow and less resin may be used. Some propagators use linseed oil instead of tallo

Clay is frequently used for covering wounds made by grafting, and it gives quite as good results as any of the waxes, if properly applied. For this purpose some very tenacious clay should be used, and it is thought to be improved when mixed with about one-third fresh cow dung and a little plasterers' hair. The whole mass should be thoroughly worked over before using.

Cleft Grafting is a very common form of grafting, and is mcre universally known and used than any other. It is commonly periormed to change the bearing of apple, plum and various other trees and plants. It is generally the most practical method to use on branches two or three inches in diameter, but it also works well on quite small stocks.

The tools used are a sharp, fine saw and a grafting chisel, a good

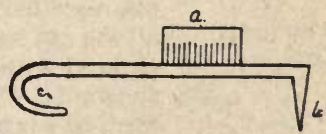

FIG. 93.-Grafting chisel. pattern for which is shown in Fig. 93 where $a$ represents blade for splitting the stick; $b$, the wedge-shape end for hulding the cleft 
open; ana $c$, a hook by which the tool may be hung on some convenient branch.

Cleft grafting is performed as follows: The place selected for the insertion of the scion should be where the grain of wood is straight. The stock is then cut "square" off with a sharp saw and is split through its center, with the grafting chisel, to a depth sufficient to allow the scion to be put in place. The cleft is held open by the chisel (Fig. 94) until the scion (Fig. 95) is cut and inserted, when the wedge is withdrawn, allowing the stock to close on the scion and so hold it in place. If the stock does not

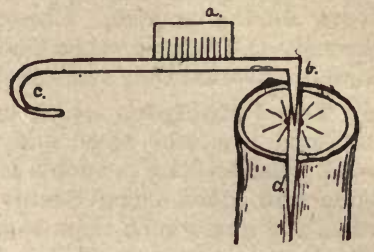

FIG. 91. - Stock cut off and split and cleft held open with wedge-shaped end of grofting chisel.

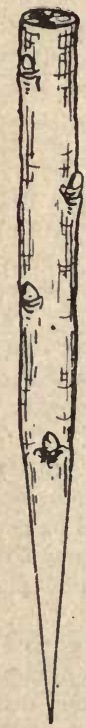

Fig. 95.

Showing the scion cut for insertion. spring back so as to hold the scion firmly it should be tightly drawn together with a string. The numbers of scions inserted will depend on the size of the stock. If the stock is not over three-quarters of an inch in diameter one scion is enough to insert, but on larger stocks two may be put in. All the cut surfaces, including the ends of the scions, should now be covered with wax, as shown in Fig. 99.

The Scion to be inserted in cleft grafting should be cut wedge-shaped lengthwise, as shown in Fig. 95, and its cross-section should resemble Fig. 96, in which $a$ shows the outer bark and $b$ the inner. Figure 97 represents a cross-section through a newly made graft, showing cleft in the stock and two scions in place (note how the edges of the wood come together). Figure 98 represents the scion and graft as seen in perspective. Figure 99 shows the appearance of the graft when completed and covered with wax.

Whip Grafting is illustrated in Fig. 100, in which $A$ represents the stock with a siit at $a ; B$ the scion with a slit at $b ; C$ the scion and stock put together. When finished all the cut surfaces should be covered with grafting wax, as shown in Fig. 99. In this form of grafting it is seldom

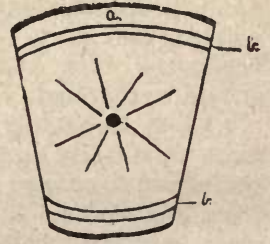

FIG. 96. - Cross-section of wedge-shaped end of scion.

that the inner barks come together on more than one side of scion and stock. It is a method that is very quickly performed by one accustomed to it, but its use is limited to branches or stems under three quarters of an inch in diameter, but for stocks coming within 


this limit it is very convenient. It is much used by nurserymen in root-grafting apple, pear and plum seedlings. It is done to a large extent during the winter months, when but very little can be accomplished out of doors. It is performed as follows:

Root-Grafting.-Seedlings which are dug in autumn and

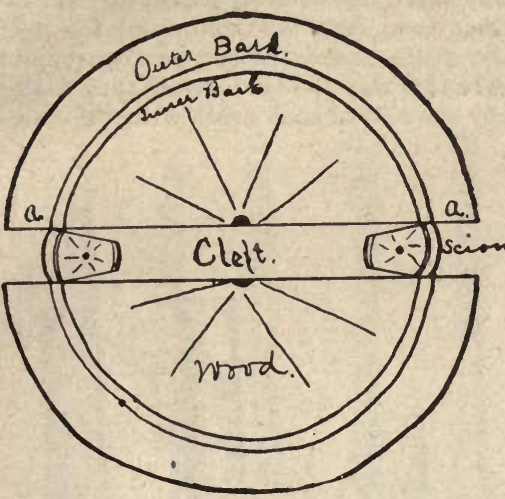
packed in moss or sawdust in a cold cellar, are taken as needed to a warm room and the scions grafted upon them just below the collar, i. e., the place where root and top are jolned. The kind of graft made is illustrated in Fig. 101, which $\mathrm{sh}$ ows the successive stages of the work. $A$ shows a seedling apple root with top removed, which is to be cut off and grafted at the cross FIG. 97.-Cross-section through a graft showing line; $B$ shows scion; $C$ cleft and scion in place. scion and stock prepared for being united, but with the cut held open. This cut is made by the knife-blade, and no wood is removed from it. $D$, the same united. $E$, the union wrapped with a strip of paper or cloth which has previously been covered with grafting wax. Some prefer waxed string for this covering. The grafts should be about eight inches long. When completed they should be tied in bundles and put away, packed very firmly in sand or light soil, in a cold cellar. Eariy in the spring they should be planted in the nursery, about six inches apart, in rows three feet apart, setting all but the upper bud of the scion below the surface of the ground. It is important to plant the scion deep so as to encourage it to throw out roots, as the trees are then more hardy than when they depend entirely on the seedling root for support. Great care should be taken to

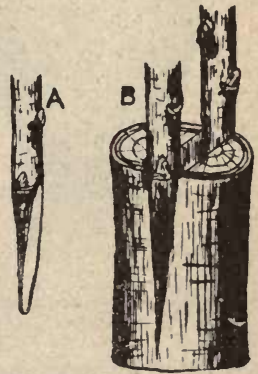

FIG. 98.-Perspective view of scion and completed graft. have the soil very firm and solid around the base of the root and at the union. This may be secured in several ways. Some nurserymen attain this end by the use of a large dibber, having a guard on the side to prevent its going too deep. With this a hole is made sufficiently wide and deep to permit the insertion of the graft 
easily so tnat not more than one or two buds project above the ground. To do this work most expeditiously the grafts should all be of the same length and free from side branches. Two persons should work together, a man who uses the dibber and a boy who carries the grafts. The man makes a hole with the dibber, the boy puts in a graft, when the man immediately makes another hole by the side of and two inches away from that containing the graft, and pressing towards the graft packs the soil firmly around it. After each row is finished in this way the man should turn back on the row and press firmly by the side of each graft with the ball of the foot.

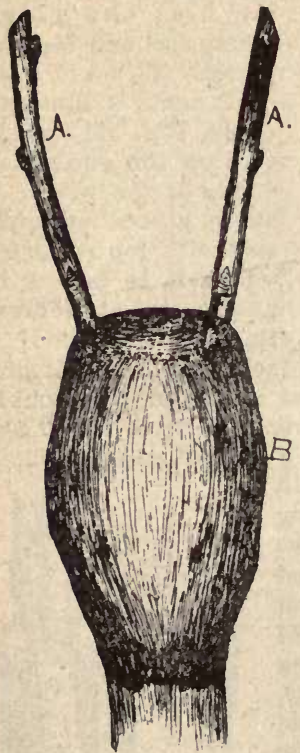

FIG. 99.-Graft covered with wax. $A A$, scions; $B$, wax.
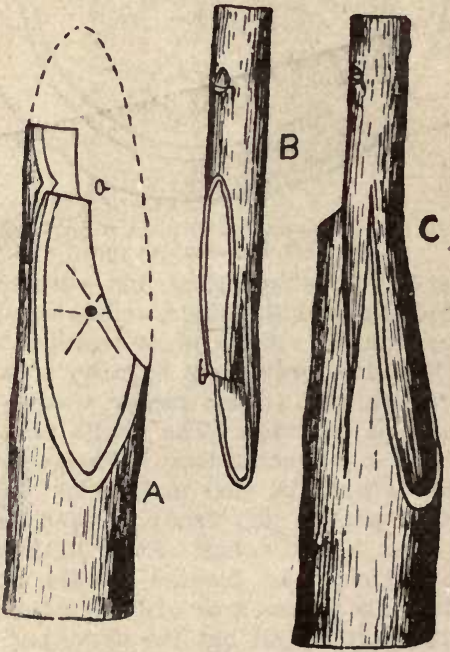

FIG. 100.-A, stock; $B$, scion; $C$, scion and stock united.

Another method of planting root grafts which is as applicable for planting cuttings on a small scale is as follows. It is not a fast method, but a very excellent one for a few grafts: The thoroughly plowed land is smoothed off, a line stretched and walked where the row is to come and then thrown to one side. With a spade throw out a furrow along the line, leaving the edge straight and smooth. Against this place the grafts, and then with a hoe turned bottom up push a little earth against the lower part of the root of each graft, and afterwards draw three inches of soil into the furrow 
around the grafts and then press firmly against each graft with the ball of the foot. Fill the trench full and repeat the footing process again. A more expeditious way is to plow out a furrow instead of making it with a spade, and then fill the trench $\nabla$ ith a plow. In this way the work may be successfully done if the soil is not dry and the season is favorable. But it pays well to do good work, and where one has only a few hundred or a thousand grafts to plant the spade method is most certain. In planting in a dry time the great key to success is to have the land firm and solid

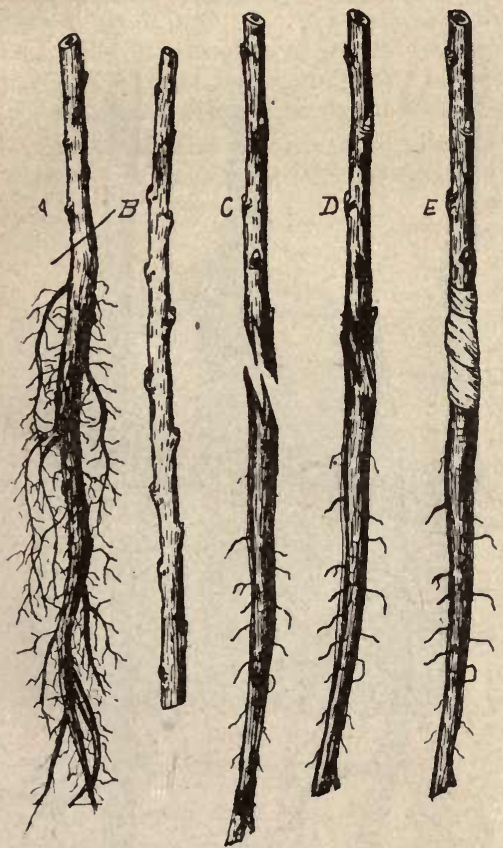

FIG. 11.--Root grafting illustrated. A, stock; $B$, scion; $U$, scion und stock prepared; $D$, graft: made; E, grafi completed and wrapped with waxed cloth. at the crown of the plant, which is just below the surface of the land. This form of grafting may be successfully used on piums, apples, and other fruits. If it is done on the branches of a tree there is no necessity of cutting off the part above the graft until the scion starts into growth.

Grafting Below Ground.-If grairing is done just below the surface of the ground the work is much more certain of being 
successful than if above the surface, and the resulting tree will be hardier than if the union were above ground, since the weakest point in a tree (the graft) will be protected by the earth. Of course very frequently it is impracticable to do the work in this manner. Figure 103 shows a grape root so grafted. The methods adapted for grafting below ground are the same as for above ground, only not so much wax is required.

In grafting below ground it is important to remove the soil until a smooth straight part is found of sufficient length to contain the scion. It is important, also, to keep the wounds free from dirt, for however $\mathrm{much} 1 \mathrm{t}$ may help to have the whole grafic covered in this way, any soil on the cut surfaces will prevent that desirable close contact of the cells which is necessary for successful work. When grafting is done below ground suckers will often start from the stock in great numbers. These should be all removed or the graft will be ruined. A little observation soon teaches one to distinguish at a glance the sprouts from the stock from the scion. In removing these suckers they should be pulled away from the stock and not simply cut off. Only one shoot should bo permittec to grow from cach scion, and this should be the thriftiest and generally that starting lowest down.

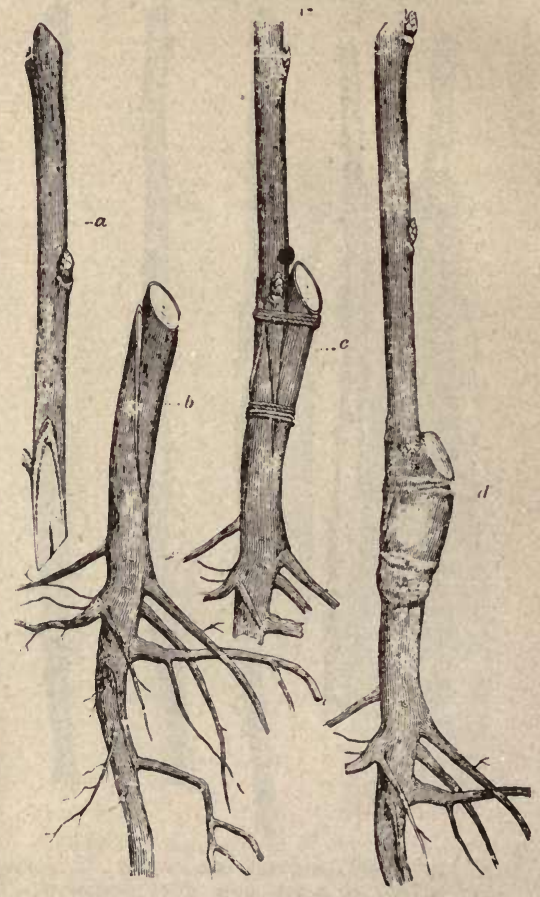

FIG. 102.-Side-grafling as practicta on cherry. $a$, scion; $b$, stock; $c$, graft maue; $d$, graft covered with wax.

The lowest is saved because wherever a shoot starts there is gencrally a crook formed, and if near the ground it is not unsightly.

Night Cap is a term given to signify a paper bag that is sometimes drawn over and tied below the graft as soon as it is completed. It is weil illustrated in Fig. 104. Its use is to prevent the shriveling of the scior due to exposure to drying winds. It is 
especially desirable in top-grafting trees in dry seasons or in exposed locations. It is a very valuable adjunct to the grafting outfit and its use should be more general. Of course the bags should be removed as soon as the scions start, and the same care should be taken in the use of wax around the graft as if the night cap was not used.

The following notes on grafting different fruits will perhaps be of interest:

Grafting Apples.-Apples in the open ground should be grafted about the time the buds are nicely started, but the scions should not have started at all. It is the easiest of all the fruits to graft, and almost any method may be used successfully on it. The scions should be from four to six inches long.

Grafting tise Plum.-The plum is most successfully grafted very early in the spring-even before the frost is out of the ground

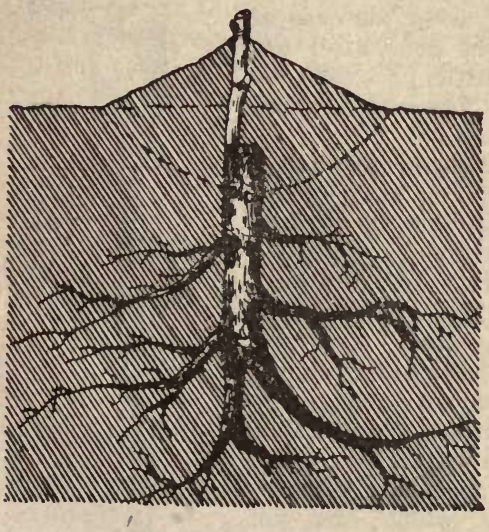

FIG. 103.-Grape vine root grafted. or a bud has commenced to swell. The work when done at this time is generally successful, though not as certain as the apple. It is said that the plum may be grafted very successfully later in the spring, even after the buds have commenced to swell, providing the buds on the scion are started as much as those on the stock at the time the work is performed.

The plum may be quite successfully root-grafted in the house in winter, as recommended for the apple and treated the same way, but it generally takes a year longer to get the tree formed, since in this case the growth from the scion is quite slow the first two years.

On account of the slow growth trees grown in this way are often crooked and unpromising. This defect, however, may be remedied by cutting away in the early spring of the second year all the growth from the scion except one strong bud at $i$ is base. If this work is done very early in the spring it will result in throwing the whole strength of the root into a single bud and the forming of a stem that is straight in place of the former crooked one. A much better and more satisfactory plan than root-grafting is to plant the stocks in the nursery one year before they are intended to be grafted, and then graft them below tho surface of the ground very early in the spring. For this purpose cleit or whip-grafting should 
be used. When the work is done in this way the resu t is a very strong growth from the scion. If the suckers are pinched off and the whole strength of the root forced into one shoot, the result, on rich land and in the case of strong, healthy stocks, will be to give a growth often exceeding four feet in height. Sometimes the growth in this latter case will be so heavy that the branches are liable to be broken off in the wind, and should be tied to stakes with soft string. The scions should be from four to six inches long.

Grafting the Cherry.-The cherry may be root-grafted indoors in the winter. When this is done what is called side-grafting is employed, and it gives results far ahead of any other method. But with the best of care the losses from in-door grafting of this fruit makes it very unsatisfactory. Much better results will be achieved by side-grafting them at the crown of the plant on stocks well established in the open ground, as in the plan recommended for propagating the plum. In regard to this fruit it is also reported that, as in the case of the plum, the work may be done after the stocks start into growth a little, providing the scions are as far advanced. The scions should be from four to six inches long.

Grafting the Grape is done most safely very early in the spring, even before a sign of growth appears, but it may also be grafted about the time the first leaves are nicely expanded, if the scions are kept dormant until that time. The work should always be done below the surface of the ground. Any form of graft may be used, but that most commonly used is cleft-grafting, as shown in Fig. 103. In making a cleft-graft upon a grape root it is often necessary to saw the cleft in the stock with a fine saw on account of the crooked, twisted grain of the wrod, which does not allow it to split straight. Some growers do not use any wax around the graft but simply cover it with a mound of well packed earth up to the upper bud of the scion. In grafting after the leaves are expanded some propagators prefer to use side-grafting, and do not cut the vine severely until it is beileved the scion has grown fast to the stock, when the

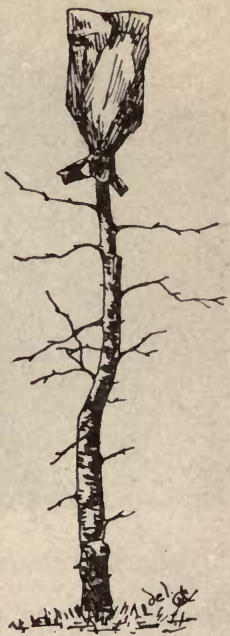

FI G. 104. - Graj*:?d plum with graft covered with night cap. vine is cut entirely away. Whip-grafting is also used for this purpose. The scions should be about six or eight inches long.

To change the varieties in a vineyard it is sometimes practiced 10 graft on a cane from the old vine. In this case a cane from the old vine long enough to reach nearly midway between the vine is grafted with a scion which should be at least two feet long. When grafted the graft, including the cane and scion, should be buried 
six inches deep, the end bud of the scion being brought above ground where the new vine is desired. The following year the old vine may be largely cut away and the growth from the scion will take its place. This method is not so neat as when the vine is cut off and grafted below at the surface of the ground, but it has the merit of being very. much more certain of not necessitating the destruction of the old vine until a new one is established.

Grafting by Approach or Inarching is a form of grafting in which the branches of growing plants are brought together. It is sometimes used to change the bearing of vines or trees, or to grow two branches or stems together. It is much used in propagating such ornamental trees as cut-leaved and purple birches. It may be done at any time during the growing season and on any flexible growth of whatever age. It is performed by shaving out a piece of bark and wood from the stock and from the scion, of the same size and in such a way that the inner barks of each may be together. If this is done even so late as the middle of July they will grow firmly together before winter. It is customary when this method is to be used for propagation to either plant a lot of small plants aroupd the one from which the scions are to come, or to grow them in pots and set pots and plants near by. When the branches have united they are permitted to grow until autumn, when the scions are cut off just below the union and the plants with the scions on them are heeled in for winter or protected in some other way. No wax is needed as the union is very sure if the parts are closely tied together. This is a very safe and sure method and is easily performed, even by the novice. 


\section{APPENDIX.}

BY PROFESSOR J. L. BUDD.

1. THE following list of apples is by Professor J. L, Budd, of the Iowa Agricultural College, whose efforts in connection with the introduction of hardy fruits for the Northwestern States have given him a national reputation. This list comprises the varieties which he considers the hardiest and best adapted to the extreme north. Many of these kinds cannot be obtained of the general nurserymen, but the list is of great value in showing the direction which progressive horticulture is taking in the extreme north and as a guide for future pianting. It is especially valuable for parties living in sections corresponding to Northern Iowa, and perhaps Southern Minnesota.

\section{APPLES. \\ SUMMER VARIETIES.}

Blushed Calville. (22 M.) This at the West will prove more valuable than Yellow Transparent. The tree is much hardier, more nearly free from blight, and the fruit is about as early, as large in size, is handsomely blushed, and it is less perishable and better in quality.

Breskovka. (152 M.) Some later than the above and a very regular and full bearer. Fruit in size, color and shape much like Grimes Golden. Quality best for kitchen use and very good for dessert.

Plodovitka. Very early and profitable at the North.

AnIsetre. (No. 185.) Of the Duchess family and hardier at the North. An annual and full bearer of fruit like Duchess, but finer in grain, less acid and earlier. Will prove valuable over a large part of the United States.

Revel Pear. (No. 379.) A heavy bearer of fair sized handsome fruit for home use or market.

Borovinka. (No. 245.) Of the Duchess family. Fruit almost identical with Duchess, but a better keeper. 


LUBSK QUEEN. (No. 444.) As hardy as Duchess and noted for heavy and continuous bearing. Fruit large, smooth, with varied shades of red and pink. Flesh fine grained, sub-acid and very good for so large a fruit. This is placed with the summer apples because it colors up early and ships well at an early date, but it keeps well at the fruit stands and can be easily kept through September.

\section{AUTUMN APPLES.}

ROsY REPKa. (No. 200.) An iron-clad tree everywhere. Fruit large, even sized, handsomely colored, sub-acid, and excellent in quality. Will be a popular market apple. Season autumn, or early winter on the north limit of its possible growth.

Hibernal. (No. 378.) Hardier than Duchess and fuly equal in bearing and perfection of tree on varied soils. Fruit large, even sized, handsomely colored and of best quality for culinary use. This will prove a popular market apple for kitchen use during the fall and early winter. It has some value for dessert use when fully matured and the skin, which has a crab-like flavor. is removed.

KeIv ReingtTe. (No. 447.) Hardier than Duchess at the North. Fruit large, smooth, yellow, with crimson splashes, and a rich bloom. Valuable for all uses. Season, late fall and early winter.

GIPSY GIRL. (56 Vor.) A fine tree in nursery and orchard. Fruit large, smonth and remarkably handsome. A famous trainboy apple in East Europe. Will be prized over a large part of the country. Season, late fall.

MaLletT. (No. 980.) As imported by the Department of Agriculture this has the name of White Pelikanoff. The fruit is not white, but is much like Wealthy in size, shape, color and quality. Its true name is Mallett. Though classed with the fall apples it is a remarkable keeper after it becomes tender enough for dessert use. As grown at the North, we have eaten the fruit in fine condition in March.

LARGE ANIs. (No. 413 Department) This was imported by the Department of Agriculture under the name of Cross apple. It is an iron-clad tree in all respects, a heavy and continuous bearer, and a valuable late fall and early winter apple of good size and excellent quality.

Antonovka. This is an iron-clad tree and an early and con. tinuous bearer of large yellow apples that will take well in market and prove valuable for home use. Its fault is tendency to blight on black soils and in sheltered localities, but it is not more subject to blight than the Yellow Transparent. Season, late fall and early winter.

Aport OrInnt. This is one of the most valuable varieties of the Alexander family. Fruit very large, gorgeously colored, and of excellent quality for an apple of its size. 
Golden Rennetre. This has not proven true to name as received from the Bogdanoff estates, in Russia. It is a member of the Anis family, of fine size and excellent quality. Season, late. fall, and early winter North.

Posarts Nalivia. Of the Antonovka family and less subject. to blight and a better keeper. Season here, December, and much later on its north limit of growth. Fruit much like the Antonovka, but it averages larger in size and is better in quality.

KURSK Reinetre. (20 M) Of the Longfield family, with the same habit of early and continuous bearing. Fruit more conical than Longfield, of same color, flesh fine grained, tender and sweet. This promises to be very valuable over a large part of the United States.

Sinkar Lraf. (No. 327.) This is one of the hardiest of the Hibernal family. A great and continuous bearer of smooth, handsome apples, especially valuable for culinary use. Season, late fall, and mid-winter at the North.

Pointed Pipka. (No. 361.) A true iron-clad and perfect tree on varied soils. Fruit large, conical, coming to a point at the nar row basin, yellow, covered with stripes and splashes of crimson, with much bloom. Flesh fine grained, sub-acid and very good. Season here, late fall, and late winter on its north limit of growth.

BERGamot. (No. 424.) This is of the Antonovka family and is classed as a winter apple by J. B. Mitchell, of Cresco, and other northern growers. The fruit is later with us than Antonovka or Posarts Nalivia, but does not keep later than December with ordinary care. A remarkable bearer and perfect tree in every way. Fruit large, even in size, bright yellow and good in quality for any use.

\section{WINTER APPLES.}

Aport Voronesh. We introduced the Aport of Central Russia from several points. It has been sent out as Aport, 23 M., 4 Vor., and 12 Orel. We have kept these importations separate, but they all appear to be identical. Fruit large, smooth, yellow, with much red in broken stripes and splashes. Flesh yellowish white, slightly coarse, sub-acid, aromatic, quality very good for any use. Mid-winter here, and will keep through winter at the North.

SkLanka Bogdanoff. This is an iron-clad tree on dry soils, and an early and continuous bearer. Fruit medium in size, yellow, conical, quality better than Baldwin. Season mid-winter, and very late on its north limit of growth.

VolaA Cross. A perfect tree on varied soils. Fruit of size of Rhode Island Greening and a much better keeper. Quality better than Baldwin.

Cross. (15 M. and No. 413.) This is the true Cross apple of Central Russia. In close sheltered positions on black soils, it is subject to blight, but like the Yellow Transparent, it blights only on points of growth. On dry soils and in airy positions it will 
prove very valuable, as it is a heavy and continuous bearer. Fruit medium to large, oblate, ribbed, yellow, with red and crimson stripes. Flesh firm, sub-acid, very good. Season here, mid-winter, and it will keep as grown in North Iowa until spring.

MARMALADE. (88 Vor.) A perfect tree on varied soils. Fruit large, yellow, blushed on sunny side. It is especiaily valuable for jellies, marmalades and other culinary uses requiring much grape sugar. Season here, mid-winter.

Ostrakofr. (4 M.) This is hardier than Duchess and less subject to bilght. An early, heavy and continuous bearer, and needs manuring to keep up size of fruit after it has borne heavy crops. Fruit medium to large, even in size, yellow. Flesh firm, sub-acid and fine in quality. Mid-winter here, and will keep until May on its north limit of growth.

LEDENETS. (30 M.) An iron-clad tree, succeeding best on dry solls without shelter at the north and west. A heavy and continuous bearer. Fruit medium to large, oblate, yellow, with blush on sunny side. Flesh fine grained, sub-acid, very good. Season, midwinter here, and very late on its north limit of growth.

LEAD. (3 M.) This also does best on dry solls without shelter. Fruit large, oblate, conical, yellow, with red on sunny side, acid and most valuable for cooking, but when ripe it is better for dessert use than Willow or Ben Davis. Mid-winter here, and much later north.

ROYAL TABLE. (5 M.) Also needs dry soil and open exposure. An early and continuous bearer. Fruit medium to large, conical, ribbed, yellow, with red on sunny side. Flesh white, fine grained, sub-acid, neariy best in quality. Mid-winter here, and late winter at the North.

REGEL. (No. 169.) This was received by the College from Dr. Regel, of St. Petersburg, under the name of Green Sweet. But a mistake was evidently made as this is not sweet, has a fine color and is a late keeping winter apple. It much resembles Repka Malenka in shape and color, but it is larger in size and of better quality. In season and flavor it is much like Rawle's Janet.

Romna. (No. 599 and 11 M.) This succeeds best on dry soil where its roots run very deep. Fruit medium in size, conical, smooth, handsomely colored. Flesh white, firm, quite acid and best for cooking, but when matured it is much better for dessert use than Willow or Missouri Pippin or other coarse sorts found in our markets. Season, mid-winter here, and late winter north of 43d parallel.

Swinsovka. (No. 277.) The Department No. 277 is lsbeled Vargul, but is not true to name. The Swinsorka is of the Lead apple family, but is not identical with $3 \mathrm{M}$. Fruit medium to large, green, with yellow on sunny side. Flesh fine grained, firm, subacid, juicy and excellent for dessert use. Season, mid-winter at Ames, and late winter north. 

APPENDIX .............. $\begin{array}{r}\text { Page } \\ \text { Pan }\end{array}$

APPLES .................... 126, 129

Crab apples................. 94

Cultivation ............... 78

Depth to plant............ 77

Diseases ................. 85

Blight................... 85

Scab................. 85

Distance apart to plant...... 78

Forming the tree........... 78

Injured trees............... 80

Insects. . . . . . . . . . . . . 86,91

Climbing cut-worm....... 89

Codling moth............ 89

Curculio ............. 90

Flat headed apple tree borer.....

Fall web worm............

Leaf lice................ 91

New York weevil........... 87

Tent caterpillar........... 87

Land best adapted to appies 74

Location of apple orchard.. 73

Location especially adapted to orcharding.............

Manuring

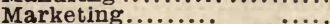

Mulching ..................

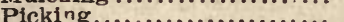

Planting................. 76

Protecting trunizs by boxing

Pruning

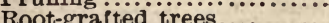

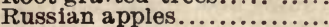

Seedlings.

Some important things to remember

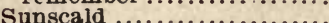

Supplementary list of apples

Time to plant

Top-working ...................

Tr.es

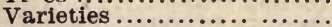

Late summer and eariy autumn................

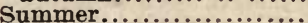

Wind-breaks .............. 74

Worst location for an orchard.

BLACRBERRIES .............

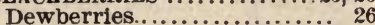

Species.................. 25

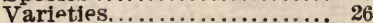

RoRdFAUX MixTURE........ 12

BUDDING . .............. 108,115

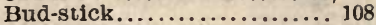

June-budding .............. 113

Necessary implements...... 110

Other forms of ............ 114

Process of ................ 110

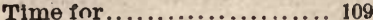

BUFF ALOBERRY...........68, 69

Description ............... 68

Propagation............... 69
Cherry ................ 104, 107

Cultivation............... 106

Diseases .................. 106

Insects .................... 106

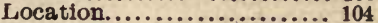

Planting................ 105

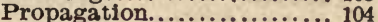

Cuttings................. 105

Suckers .................... 105

Pruning ................... 106

Soll ........................... 104

Varieties ................. 107

Cranberry..............58, 62

A bout flowing .................. 60

Best location for beds....... 59

Drainage and flowage........ 60

Importance of water........ 60

Picking.................... 62

Plants and planting ........ 61

Preparation of land ........ 59

Soll adapted to it........... 59

Supplying sand.............. 59

Currants..................27, 35

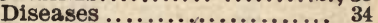

Insects......................... 31

Currant worm........... 31

Imported currant borer... 33

Lice................... 33

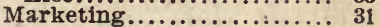

Mulching................... 29

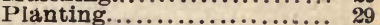

Propagation.............. 28

By cuttings.............. 28

By layers............... 28

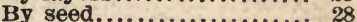

Pruning .................. 29

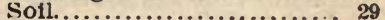

Species....................... 27

Tree currants............. 30

Varieties ................... 34

Winter protection......... 31

DEWBERRIES ................ 26

DISEASES OF THE-

A pple.................85, 86

Currants. ........................ 34

fooseberry..................... 54

Grape........................ 53,5

Raspberry..............22, 23

Strawberry ................... 12

GOOSEBERRY ................ $3 \%$

Mildew ..................... 66

Planting ................... 36

Propagation ................ 36

Pruning . ................. 36

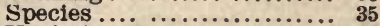

Varieties.................. 37

GRAFTING BY APPROACH,

INARCHING .............. 125

GRAFTING .................

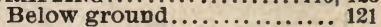

Cleft-grafting ............. 117

Night cap................. 122

Root-grafting ............. 119

Scion $\ldots \ldots \ldots \ldots \ldots \ldots \ldots \ldots \ldots . . \ldots 116$ 
Graftravg-Continued. Page.

Side-grafting.............. 121

Stock $\ldots \ldots \ldots \ldots \ldots \ldots \ldots \ldots 116$

Whip-grafting .... ...... 118

Gra FTING WAX............. 117

GRAPE $. . . \ldots \ldots \ldots \ldots \ldots \ldots \ldots \ldots 38,57$

Bagging fruit............ 52

Best vines................ 43

Cultivation................ 44

Diseases .................. 53

Downy milidew............ 54

Black rot.............. 54

Distance between plants.... 43

Fungicides, use of ......... 55

Ammonlacal carbonate of copper

Girdling $\ldots \ldots \ldots \ldots . . . . . . . .$.

Insects................. 56

Eight spotted forester..... 56

Grape-vine flea beetle..... 56

Keeping fruit ............. 52

Layering .................. 41

Spring layers............ 41

Summer layers ........... 41

Location of vineyard....... 42

Manures................. 51

Planting.................... 43

Preventives of disease........ 54

Propagation ............... 39

Cuttings................ 39

Seed .................... 39

Pruning and training ........ 44

Pruning, easy system ....... 49

Pruning neglected vines.... 50

Pruning, time of........... 51

Removing follage.......... 49

Soll ..................... 43

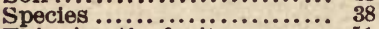

Thinning the fruit........... 51

Training vines against build. ings or walls

Trellis ....................

Varieties ................ 56

Varleties, list recommendë 5 r

INSECTICIDES-

Kerosene emulsion.......... 91

Paris green.................. 90

Tobacco water.............. 91

INSECTS INJURIOUS TO-

Apple.

86,91

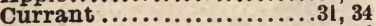

Grape....................... 56

Raspberry $\ldots \ldots \ldots \ldots \ldots \ldots \ldots . \ldots \ldots, 24$

Strawberry ...............12, 13

JUNEBERRY, DWARF........6. 63,65

Cultivation.............. 64

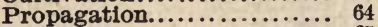

Varieties.................. 65

K EROSENE EMUISION......... 91

Mulberry, Russian .........70, 71

Hardiness ................ 70

Its frutt. .................. 71

Propagation................ 71

Varieties ................. r

PLUM, THE.................. 103

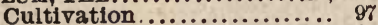

Diseases..................... 101

Black rot, or Wart of the nlum................. 100

Diseases, other.............. 101
Plum Pockets............. 100

Insects ................... 101,103

Aphis, or Leaf Lice........ 103

Plum Curcuito............ 101

Plum Gonger............... 102

Location .................. 97

Marketing................. 98

Mixing varieties.............. 98

Planting ................... 97

Profits of cuitivation......... gr

Propagation ............... 96

Pruning ................... $g^{7}$

Renewing old trees.......... 97

Spectes ................... 95

Suckers, thrifty............ 96

Varieties .................. 99

RASPBERRIES ................. 25

Convenient box holder...... 22

Cultivation............... 18

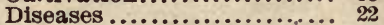

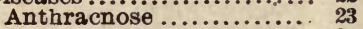

Leaf curl................. 22

Red orange rust............ 22

Insects..................... 23

Flat-headed borer........ 23

Snowy tree cricket........ 23

Location ................. 17

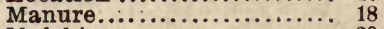

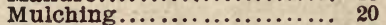

Planting ................... 18

Preparation of land......... 18

Propagation ............... 16

Layers................. 17

Root cuttings............. 16

Seed .................... 16

Pruning and thinning....... 19

Selection of plants......... 18

Soll ...................... 17

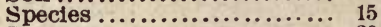

Support.................... 20

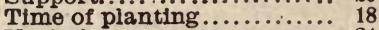

Varieties.................. 24

Winter protection............ 21

STRAWBERRIES ............. 5,14

Avolding frosts............ 9

Bordeaux mixture.......... 12

Diseases .................. 11

Dry berries-"nubbins" "..... 11

How to continue in bearing. 9

Insects.................. 12

Leaf roller............... 12

White grub................ 12

Location................... 6

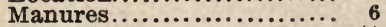

Marketing................ 11

Methods of planting......... 7

Hill system............. 7

Matted row system......... 8

Plcking.................. 11

Preparation of land......... 6

Propagation............... 5

Sexuality of biossoms............ 10

Shading the bed............ 13

Soll $\ldots \ldots \ldots \ldots \ldots \ldots \ldots \ldots \ldots \ldots$. 6

Species....................... 5

Time of planting............. ?

Trimming and setting plants 8

Varteties ................. 14

Winter protection............ 9 






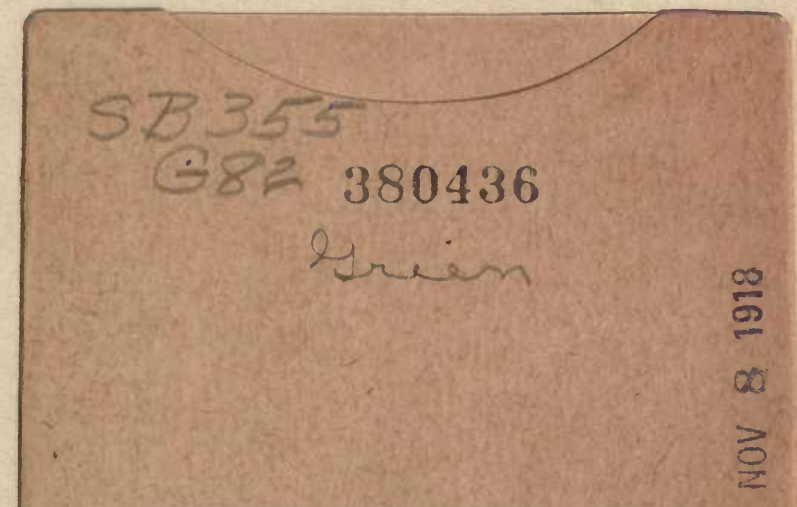

UNIVERSITY OF CALIFORNIA LIBRARY

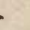


